\title{
Pathobiology of the Flaviviruses
}

\author{
Thomas P. Monath
}

\section{INTRODUCTION}

Among arthropod-borne and related viruses, the Flaviviridae are medically the most important group and biologically one of the most intriguing. Elucidation of perplexingly complex virus- and host-specified factors that underlie virulence and pathogenesis has lagged behind other areas of virology, and the available information is largely descriptive. Ultimately, flavivirus biology and pathogenesis will be understood in terms of viral gene expression, virus receptor-host cell membrane interactions, biochemical alterations in host cells, physiological responses, and immune and nonimmune mechanisms that control virus replication and virus spread, subjects to which other chapters in this book are devoted. There will remain, however, a need to understand and synthesize this information with observations relating to infection at the level of the intact organism (virus, vector, and host) and of populations of organisms in nature. It is at these levels that the phenomena that require explanation first present themselves.

Central themes in flavivirus biology are the variation in virulence of virus strains and susceptibility or resistance of vector and host individuals and populations. The remarkable evolutionary diversity and genetic plasticity of the flaviviruses provides both natural and laboratoryderived mutants with differing virulence properties for molecular and biological studies. Natural variation among flavivirus strains in virulence for clinical hosts and infectivity for vectors and reservoir hosts is more

THOMAS P. MONATH - Division of Vector-Borne Viral Diseases, Center for Infectious Diseases, Centers for Disease Control, Public Health Service, U.S. Department of Health and Human Services, Fort Collins, Colorado 80522. 
important than is generally appreciated and is discussed further below. The contribution of host genes to the control of flavivirus infections in laboratory models is reviewed in Chapter 11; mention will be made below of evidence for genetic control in clinical and biological hosts.

Some principles that underlie study of viral pathogenesis include: (1) definition of the target cells and tissues for replication and injury; (2) separation of injury due to primary virus-induced cytopathology from secondary immunological or physiological mechanisms; and (3) elucidation of the mechanisms tht control viral spread (R. W. Schlesinger, 1980). These principles will be used as a framework for this review of flavivirus pathobiology, while recognizing, as pointed out by Murphy (1979), that an understanding of the mechanisms involved ". . . is always hindered by an inability to separate the virus-host interactions in each directly and indirectly affected organ and tissue."

This chapter will focus on vertebrate hosts in their role as diseased organisms. The interactions of viruses and arthropod vectors, while interesting and important in flaviviral biology, are beyond the scope of this review.

\section{MEDICAL IMPORTANCE OF THE FLAVIVIRUSES}

Of the 61 currently recognized viruses, $28(46 \%)$ have been associated with disease in humans (Table I). Three viruses, dengue, yellow fever, and Japanese encephalitis (JE), are prevalent enough to engender global or panregional public health concern. Classic dengue, a self-limited disease characterized by fever, rash, headache, and arthralgia, occurs in epidemic form in the Caribbean basin, Southeast Asia, East Africa, and Oceania, annually affecting hundreds of thousands to millions of persons. Dengue hemorrhagic fever (DHF), first recognized as a nosological entity in 1954, is an immunopathological disease characterized by hemoconcentration and a hemorrhagic diathesis and, in its extreme form [dengue shock syndrome (DSS)], by a protein-losing shock state and a $5-10 \%$ case fatality rate. Some 10,000-20,000 cases of DHF/DSS occur annually in Southeast Asia; in 1981, the disease appeared for the first time in epidemic form in the western hemisphere (Cuba; 10,000 cases).

Yellow fever remains an important health problem in tropical America and Africa. In the past 20 years, recurring outbreaks in West Africa have affected nearly 250,000 persons. The disease is characterized by fever, hepatic, renal, and myocardial dysfunction, and hemorrhage and has a case fatality rate of approximately $20 \%$.

JE occurs in endemic and epidemic form over a wide area of Asia. Morbidity and mortality estimates are inaccurate and incomplete, but it is certain that tens of thousands of cases occur annually. In Thailand, for example, the annual incidence in childhood populations is 20-50 cases per 100,000 (C. H. Hoke, S. Jatanesen, and D. S. Burke, unpublished). The 


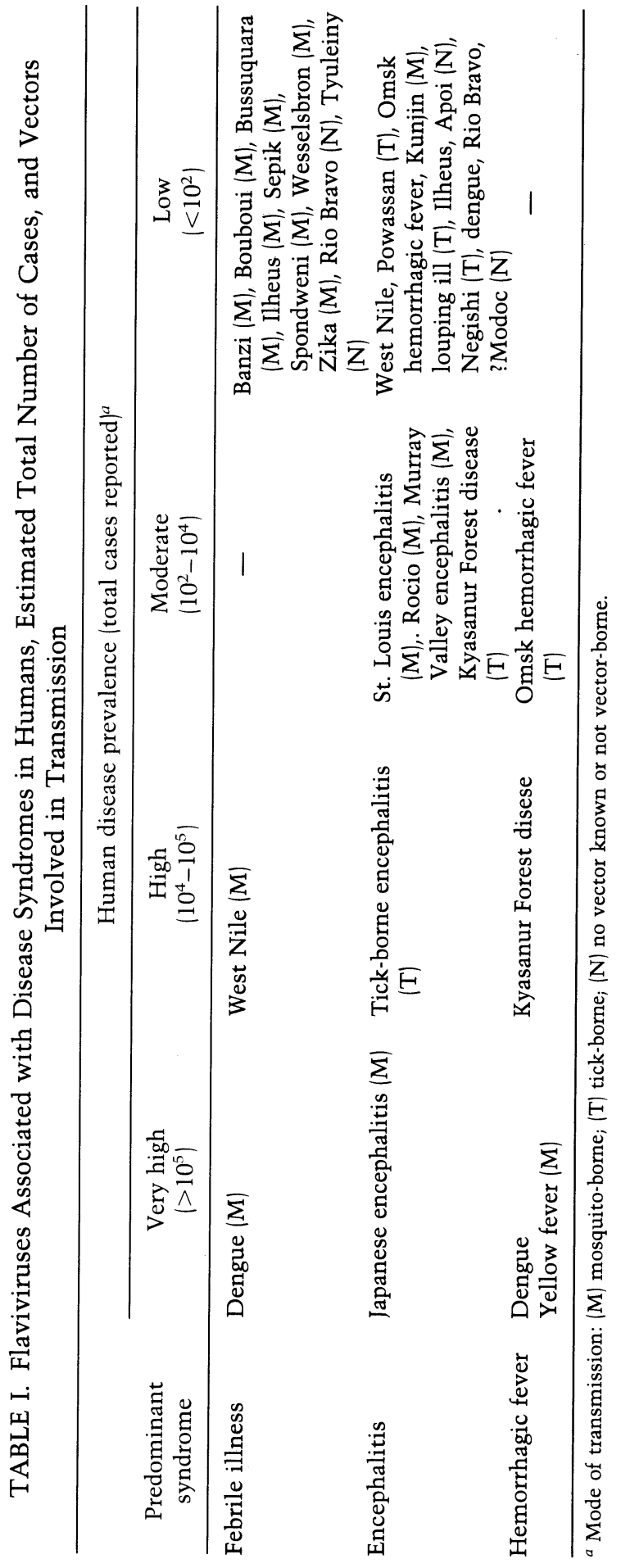


TABLE II. Flaviviruses Associated with Disease in Animals of Economic Importance

\begin{tabular}{|c|c|c|c|c|}
\hline Virus & Species affected & Disease & Distribution & Incidence \\
\hline \multirow[t]{2}{*}{$\begin{array}{l}\text { Japanese } \\
\text { encephalitis }\end{array}$} & Horse & Encephalitis & Asia & $\begin{array}{l}\text { Low-moderate, } \\
\text { regionally } \\
\text { high }\end{array}$ \\
\hline & Pig & $\begin{array}{l}\text { Stillbirth, decreased } \\
\text { spermatogenesis }\end{array}$ & Asia & High \\
\hline Louping ill & $\begin{array}{l}\text { Principally } \\
\text { sheep; also } \\
\text { cows, pigs, } \\
\text { horses, captive } \\
\text { red grouse, and } \\
\text { deer }\end{array}$ & Encephalitis & $\begin{array}{l}\text { Scotland, northern } \\
\text { Ireland }\end{array}$ & Moderate \\
\hline Wesselsbron & $\begin{array}{l}\text { Sheep, } \\
\text { occasionally } \\
\text { cows }\end{array}$ & $\begin{array}{l}\text { Abortion, hepatitis/ } \\
\text { hemorrhage, } \\
\text { congenital } \\
\text { malformation }\end{array}$ & Africa & Low-moderate \\
\hline $\begin{array}{l}\text { Israel turkey } \\
\text { meningo- } \\
\text { encephalitis }\end{array}$ & Turkeys & Encephalitis & Israel & $\begin{array}{l}\text { Outbreaks in } \\
1950 \mathrm{~s}\end{array}$ \\
\hline $\begin{array}{l}\text { Omsk } \\
\text { hemorrhagic } \\
\text { fever }\end{array}$ & Wild muskrats & Encephalitis & Western Siberia & $\begin{array}{r}\text { Intermittent } \\
\text { epizootics }\end{array}$ \\
\hline West Nile & Horses & Encephalitis & Africa, Europe & Rare \\
\hline Kunjin & Horses & Encephalitis $^{a}$ & Australia & Rare \\
\hline $\begin{array}{r}\text { Murray Valley } \\
\text { encephalitis }\end{array}$ & Horses & ?Encephalitis ${ }^{b}$ & Australia & ?Rare \\
\hline
\end{tabular}

${ }^{a}$ Badman et al. (1984).

${ }^{b}$ Association on serological grounds only; etiological relationship to MVE not established.

case fatality rate is approximately $20 \%$, and a high proportion of survivors are left with permanent neuropsychiatric impairment.

Three other flaviviral infections, West Nile (WN) fever, tick-borne encephalitis (TBE), and Kyasanur Forest disease, are less prevalent but assume considerable importance in certain regions. WN virus is widely distributed in Africa, the Middle East, Europe, and Asia. In hyperendemic areas, relatively mild infection occurs early in childhood, and adult populations are largely immune, but in regions of less intense virus activity, epidemics occur, affecting all age groups (McIntosh et al., 1976). The severity of disease increases with age; adolescents and young adults experience denguelike disease, whereas the elderly sometimes develop meningoencephalitis (Marburg et al., 1956).

TBE is a widespread endemic disease in eastern Europe, the U.S.S.R., and Scandinavia, causing hundreds to thousands of cases annually. Human infection is acquired by tick bite or by consumption of unpasteurized goat or sheep milk or cheese. Case fatality rates vary from 1 to $30 \%$; the disease in the far eastern regions of the U.S.S.R. is more severe and residual neurological damage more frequent than in Europe. 
FIGURE 1. Predominant disease patterns associated with flaviviral infections, with examples of individual viruses. (YF) Yellow fever; (WESS) Wesselsbron; (KFD) Kyasanur Forest disease; (OMSK) hemorrhagic fever; (JE) Japanese encephalitis; (SLE) St. Louis encephalitis; (TBE) tick-borne encephalitis; (BUSS) Bussuquara; (DEN) dengue; (WN) West Nile; (SPO) Spondweni; (BAN) Banzi.

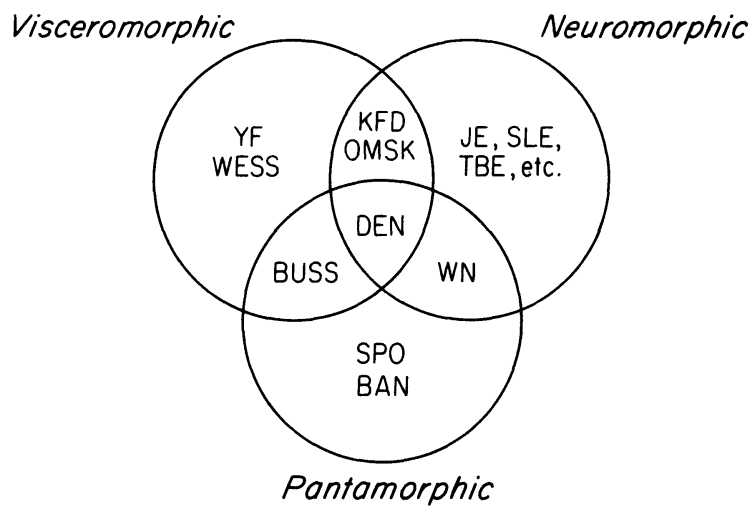

Kyasanur Forest disease, first discovered in 1957, affects human populations in several districts of western and southwestern India, where hundreds of cases occur annually. The largest epidemic occurred in South Kanara District in 1983-1984, with 1573 cases and 191 deaths. The disease is characterized by fever, headache, myalgia, lymphadenopathy, cough, and hemorrhage; a mild form of meningoencephalitis is a frequent complication. The case fatality rate is $1-10 \%$.

Three other viruses listed in Table I, St. Louis encephalitis (SLE), Murray Valley encephalitis, and Rocio encephalitis, occur as intermittently epidemic diseases in North America, Australia, and Brazil, respectively. Omsk hemorrhagic fever, which caused an epidemic of human disease in the late 1940s, now occurs as an endemic affliction of hunters and trappers in western Siberia (Casals et al., 1970).

Eight flaviviruses have been reported to cause disease in domesticated or wild animals of economic importance (Table II). The most important of these is JE, which causes epizootic encephalitis in horses and stillbirth/abortion and decreased fecundity in swine in many areas of Asia. Wesselsbron virus is associated with abortion, congenital malformation, and severe neonatal disease in lambs in southern Africa. Louping ill virus produces an encephalitic illness in sheep in parts of the British Isles.

As shown in Table I, flavivirus infections are expressed in three main disease patterns: nondescript febrile illness (pantamorphic infections), encephalitis (neuromorphic infections), and hemorrhagic fever (visceromorphic infections). Although there is considerable overlap among these disease patterns (Fig. 1), they do reflect differing tropisms for critical target organs, virulence, and evolutionary direction.

\section{PATHOBIOLOGICAL SIGNIFICANCE OF NATURAL VIRUS VARIATION AND HETEROGENEITY}

Heterogeneity of virions contained in flavivirus strains isolated from natural hosts and vectors with respect to phenotypic markers, including 
neurovirulence, has been repeatedly demonstrated. Eckels et al. (1976) found a mixture of large and small plaques in dengue 2 virus isolated from a human and showed that the small-plaque marker correlated with low mouse virulence and temperature sensitivity, as well as attenuation for nonhuman primates (Harrison et al., 1977). JE virus strains isolated from the brains of human patients in Thailand were found to differ significantly in their $T_{1}$-resistant RNA oligonucleotide maps from concurrently isolated pig and mosquito strains, suggesting selective replication of a neurovirulent subpopulation in the brain (Burke et al., 1985a). This observation may be analogous to studies with Semliki Forest virus in which a virulent strain replicated to higher titer in brain organ cultures, whereas growth of both virulent and attenuated strains was similar in extraneural tissues (Fleming, 1977).

Wild dengue virus strains of different origin have not been compared with respect to their virulence characteristics, in part because of the lack of suitable or practical laboratory models. Biological variation can be inferred, however, from epidemiological observations. In Thailand, dengue hemorrhagic fever with shock syndrome (DHF/DSS) occurs almost exclusively in persons with secondary infection with a heterologous serotype; the risk of developing DHF/DSS following secondary infection with dengue type 2 is significantly higher than for other serotypes (Sangkawibha et al., 1984). In contrast, in Indonesia, secondary infections with dengue type 3 are the most frequent cause of DHF/DSS (Gubler et al., 1979|, suggesting that virulence differences exist between dengue 2 and dengue 3 strains in the two countries. In addition, primary infection with dengue 2 virus was associated with DHF/DSS and deaths during an outbreak in Nieu island in 1972 (Barnes and Rosen, 1974), indicating that some strains of dengue possess unusual potential to cause hemorrhagic disease.

In a recent study, Halstead et al. (1984) compared antibody-dependent infection enhancement of seven dengue 2 strains in an Fc-receptor-bearing macrophage cell line. Dengue specific- and group-reactive monoclonal antibodies were used in the analysis, and enchancement of dengue replication was associated with epitopes of both specificities. The virus strains were heterogeneous with respect to the distribution of enchancement epitopes. Although variation in this group of viruses did not correlate with disease severity or geographic origin, the study provides a basis for testing and predicting immune enchancement and disease severity in sequentially infecting pairs of heterologous dengue viruses.

JE strains were found to vary in peripheral virulence for 3-week-old mice, with differences between intracerebral and subcutaneous $\mathrm{LD}_{50}$ ranging from 1.0 to 6.8 (Huang, 1957, 1982). Peripheral virulence in mice correlated with viremia level and duration and with thermostability of the virus. Virus strains isolated from humans and pigs (the principal amplifying host) were invariably neurovirulent, whereas $10 \%$ of strains from mosquitoes had low virulence. Huang (1982) speculated that the main- 
TABLE III. Concordance between St. Louis Encephalitis Viremias in Nestling House Sparrows and Neurovirulence for Mice ${ }^{a}$

\begin{tabular}{lcccc}
\hline $\begin{array}{c}\text { Mouse } \\
\text { virulence }\end{array}$ & $\begin{array}{c}\text { Number of } \\
\text { strains tested }\end{array}$ & $\begin{array}{c}\text { Proportion } \\
\text { viremic }\end{array}$ & $\begin{array}{c}\text { Duration } \\
\text { (days) }\end{array}$ & Peak titer $^{b}$ \\
\hline Virulent & 15 & 0.94 & 3.18 & 4.20 \\
Intermediate & 7 & 0.66 & 1.78 & 2.64 \\
Avirulent & 5 & 0.24 & 0.44 & 0.75 \\
\hline
\end{tabular}

${ }^{a}$ After Bowen et al. (1980).

${ }^{b} \log _{10}$ PFU/ml.

tenance of neurovirulent strains in nature may require cycling through biological hosts, such as young birds (ducklings), which sustain brain infections, and that attenuated strains arise by persistent inherited (transovarial) infection of mosquitoes. The latter hypothesis is given weight by laboratory (Stollar and Shenk, 1973; Stollar, 1980; Kuno, 1982) and field studies (Reeves et al., 1958) with mosquito-borne togaviruses, which indicate that viruses from persistently infected arthropods or arthropod cells develop markers of attenuation (reduced neurovirulence, small plaque size, temperature lability or sensitivity).

Oligonucleotide mapping of JE strains from Thailand (Burke et al., 1985a) indicated a high level of genotypic conservation among isolates from brains of fatal human cases compared to isolates from mosquito vectors. A geographic difference was noted that appeared to correlate with human pathogenicity: Virus strains recovered from pigs in southern Thailand, where intense virus transmission occurs in the virual absence of human encephalitis, differed from strains in the north, where JE causes annual epidemics.

Biological characteristics of SLE virus strains from different sources and geographic localities have been described (Bowen et al., 1980; Monath et al., 1980b; Mitchell et al., 1983). Virus strains weere classified as highly virulent, intermediate, or attenuated for weanling mice on the basis of their intraperitoneal/intracerebral $\mathrm{LD}_{50}$ ratios (Monath et al., 1980b). Virulence was associated with high viremia and replication in extraneural tissues and earlier appearance of virus in the brains of mice. Mouse virulence correlated with clinical and histological markers of pathogenicity for intracerebrally inoculated rhesus monkeys. The same virus strains were used to inject a natural host of SLE, the house sparrow (Passer domesticus), as well as 3-week-old chickens (Bowen et al., 1980). A high degree of concordance was found between level and duration of viremia in birds and neurovirulence for mice and monkeys (Table III). Mitchell et al. (1983) determined the infectivity of mouse-attenuated and virulent SLE virus strains for Culex pipiens quinquefasciatus mosquitoes and again found a correlation. All viruses replicated to high titer if the midgut barrier was bypassed by intrathoracic inoculation, but only the mouse- 
virulent strains were able to cause disseminated infections in mosquitoes fed virus by the oral route.

A number of points of epidemiological significance emerged from these studies. Virus strains isolated from birds (the usual viremic hosts for SLE) were highly virulent, whereas strains from unusual hosts, rodents and carnivores, were attenuated, possibly representing dead-end or persistent infections. All virus strains recovered during major epidemics in the eastern United States, where the virus is transmitted by C. pipiens or C. nigripalpus, were highly virulent, whereas strains from the western United States (transmitted by C. tarsalis) were relatively attenuated. This observation supports the hypothesis (Chamberlain, 1958) that the lower viremias of birds caused by western SLE strains favor transmission by the more highly susceptible vector species $C$. tarsalis over $C$. pipiens. Furthermore, the lower virulence for mice of these strains appears to correlate with the lower human case fatality rates of SLE in the western United States (Monath, 1980).

The biological characteristics of SLE virus strains were related to genetic analyses by Trent et al. $(1980,1981)$. On the basis of similarity among oligonucleotide fingerprints, 57 virus strains from North America could be classified into three "topotypes," representing different geographic areas (the Ohio-Mississippi Basin, Florida, and the western United States) and virus-vector relationships (C. pipiens, C. nigripalpus, and C. tarsalis, respectively). There was significant covariation among genetic, epidemiological, and biological markers (Table IV). Virus strains isolated within 5- to 10-year periods in a region or associated with an epidemic period spanning several years had similar RNA fingerprints, but over longer periods of time, genetic drift was evident. Monoclonal antibodies raised against a single strain of SLE virus were able to detect antigenic differences among virus strains from various geographic areas (Roehrig et al., 1983).

Strains of WN virus from Nigeria were compared by Odelola and Fabiyi (1977). Two of seven strains showed similar patterns of virus growth in organs of baby mice, whereas the other strains varied. Kinetic hemagglutination-inhibition tests showed that the two biologically similar strains were also antigenically identical (Odelola and Fabiyi, 1978). Six strains of WN virus from India showed varying degrees of pathogenicity for adult mice inoculated intraperitoneally (Umrigar and Pavri, 1977).

Three strains of WN virus, all of which had undergone a large number of laboratory passages, were studied in human cancer patients (Parks et al., 1958). In the case of these viruses, covariation was not observed between virulence for laboratory rodents and primates (Table V); the strain with the highest mouse neurovirulence (WN 1) was not associated with central nervous system (CNS) disease in humans and produced minimal symptomatology and histopathology in intracerebrally inoculated monkeys. These results stand in contrast to those with SLE (Monath et al., 


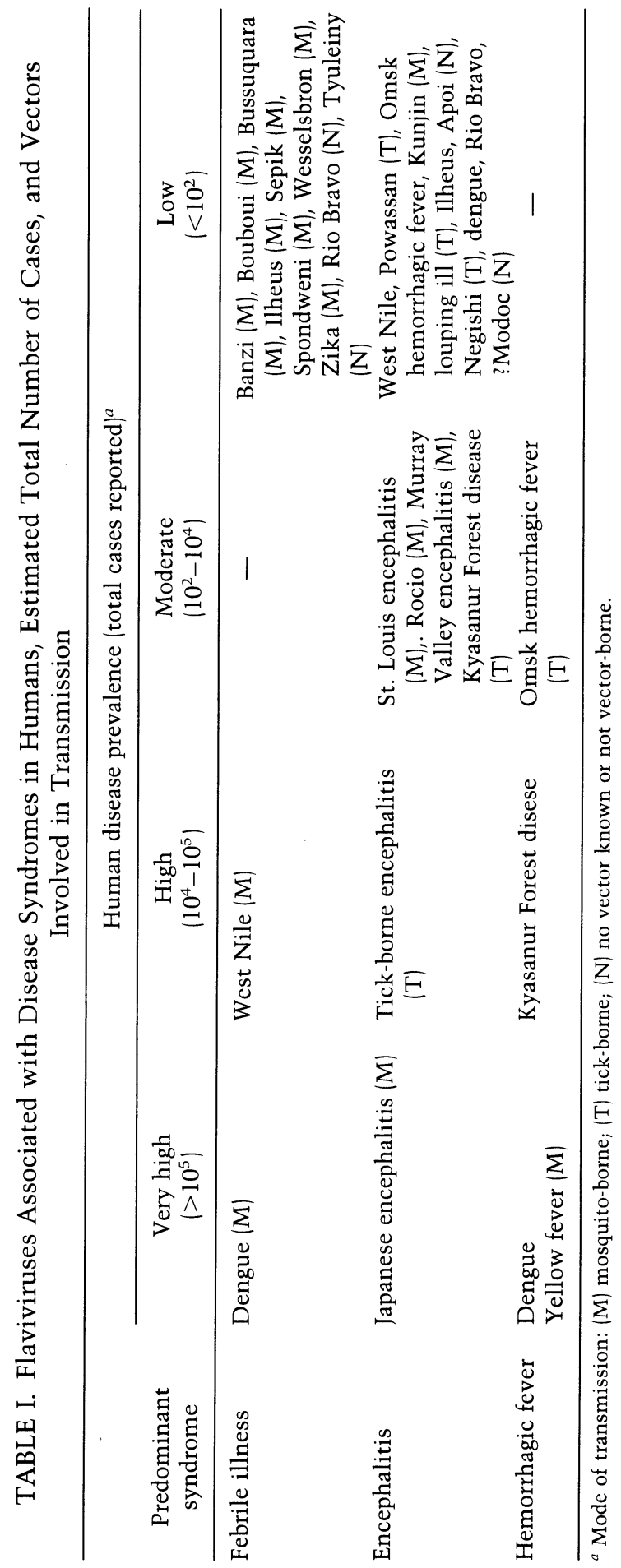


TABLE V. Biological Properties of Three Laboratory Strains of West Nile Virus $^{a}$

\begin{tabular}{|c|c|c|c|c|c|}
\hline \multirow[b]{2}{*}{ Strain } & \multicolumn{5}{|c|}{ Virulence/pathogenicity $^{b}$} \\
\hline & Human & $\begin{array}{l}\text { 8- to } 10- \\
\text { gram mice } \\
\left.\text { (ip/ic } L_{50}\right)\end{array}$ & $\begin{array}{l}\text { Hamsters } \\
\left(\text { ip } L_{50}\right)\end{array}$ & $\begin{array}{l}\text { Chicken } \\
\text { (viremia) }\end{array}$ & $\begin{array}{c}\text { Monkeys } \\
\text { (ic) }\end{array}$ \\
\hline EG 101 & High & 0.08 & 5.2 & High & High \\
\hline WN 1 & Intermediate & 0.49 & 8.1 & Intermediate & Low \\
\hline Len 75 & Low & 0 & 3.0 & Low & Intermediate \\
\hline
\end{tabular}

${ }^{a}$ Modified from Parks et al. (1958).

${ }^{b}$ High $=$ meningoencephalitis in $9 \%$ of cases $;$ intermediate $=$ generalized febrile illness; low $=$ lowgrade without symptoms. (ip) Intraperitoneal; (ic) intracerebral.

1980b) and with wild strains of yellow fever virus (Fitzgeorge and Bradish, 1980), which showed correlations between virulence for mice and primates, and thus underscore the need for caution in interpretation of phenotypic differences.

Strains of TBE from the far eastern U.S.S.R. transmitted by Ixodes persulcatus, and from Europe, transmitted by I. ricinus, are distinguishable on the basis of serological tests with polyclonal (Clarke, 1960, 1964) and monoclonal antisera (Heinz et al., 1982; Stephenson et al., 1984), pathogenicity for sheep and monkeys (Zilber, 1960), and clinical expression in humans. A high degree of antigenic conservation and similarity in peptide maps of nonstructural proteins (Heinz and Kunz, 1982) was evident among strains representing the European subtype of TBE. The far eastern strains are characterized in humans by a predilection for infection of the brainstem and upper cervical cord, a high (up to $35 \%$ ) case fatality rate, and residual damage in $30-60 \%$ of survivors. In contrast, the European subtype causes diffuse meningoencephalitis and is associated with a lower lethality $(1-5 \%)$. These differences are mirrored in the response of sheep and monkeys to intracerebral inoculation (Zilber, 1960; Ilienko and Pokrovskaya, 1960). In addition, Chunikhin and Kurenkov (1979) showed that virus strains isolated from I. persulcatus (the vector in the Far East) produced high-titered viremias in voles (Clethrionomys glareolus), a common host species, whereas strains from I. ricinus did not; this ecological marker, which was stable on repeated vole-vole passages, may be important in the maintenance of vector associations and virus subtype identity in areas of sympatric distribution.

Biological heterogeneity of TBE strains from a single biotype has also been described. Strains isolated in the Khabarovsk region and Sakhalin Island from I. persulcatus could be divided on the basis of neurovirulence and viremia in mice, plaque size, and physiochemical markers into two allopatric groups representing different landscape zones (Vereta et al., 1983). Similar findings were reported by Nawrocka (1975); strains from one natural focus in Poland showed reduced mouse neurovirulence com- 
pared to other strains. An unusual viral isolate (Skalica) recovered from C. glareolus in Czechoslovakia was found to be both nonpathogenic for mice by the peripheral route and temperature-sensitive (Gresikova and Sekeyova, 1980); these markers were retained after passage through $I$. ricinus (Gresikova and Nosek, 1983). The Skalica strain produced no detectable viremia in C. glareolus voles and negligible viremias in several other wild rodent species (Kozuch et al., 1981). Isolations of temperaturesensitive $(t s)$ arboviruses from natural sources have not been frequent, may represent adaptations to persistent infection of host or vector, and may in fact be more common than currently recognized, since virus isolation techniques employed in most laboratories select against $t s$ properties.

The wide variation among flavivirus strains in virulence and antigenic markers reflects the widely accepted high mutation rates of RNA viruses (Holland et al., 1982; Holland, 1984) and emphasizes the potential importance of virus evolution to biological and epidemiological phenomena. It is also important, however, to reiterate that flavivirus genomes can be classified geographically (Trent et al., 1980, 1981; Repik et al., 1983), that genotypes and virulence phenotypes covary (Monath et al., 1980b; Trent et al., 1980), and that successful or dominant virus variants appear to persist in a given area for 10-20 years or more. The requirement that flaviviruses be cyclically transmitted between vertebrate hosts mounting effective viremias and susceptible arthropod vector species appears to provide an element of evolutionary stability. Arthropods, which develop noncytopathic persistent infections, lack the antiviral defense mechanism of vertebrate hosts and may sustain active infections over prolonged periods (e.g., hibernation or transovarial passage to subsequent generations); these features appear to favor genetic drift or selection toward $t s$ and avirulent variants. Such variants may occasionally be transmitted to or develop in vertebrate hosts as well, but these events will be relatively unsuccessful in sustaining virus transmission cycles. Changes in susceptibility of vertebrate hosts (usually acquired in the form of immunity) or arthropod populations (genetically determined changes in vector competence) may also exert strong pressure for selection of virus variants.

\section{PATHOGENESIS OF FLAVIVIRAL ENCEPHALITIS}

Neurotropism and neuromorphic disease expression is a biological common denominator linking the flaviviruses. In clinical hosts, many viruses usually associated with generalized infections or hemorrhagic fevers (e.g., dengue, yellow fever, Kyasanur Forest disease, Omsk hemorrhagic fever) occasionally cause neurological disease. All flaviviruses are neurotropic in laboratory rodents, many biological hosts, and even arthropod vectors in which brain and ganglia are major sites of replication. 
This remarkable property may reflect evolutionary conservation of viral envelope proteins involved in receptor interactions with host cells and a wide distribution in nature of cell membrane antigens or molecules, such as neutrotransmitters, which subserve virus-receptor interactions. Preliminary evidence suggests a role for neurotransmitter molecules as receptors in the case of some alphaviruses and rhabdoviruses (Tignor et al., 1984), but no studies have been reported with flaviviruses. A wide natural distribution of nerve-cell membrane antigens, as shown by crossreactivity with monoclonal antibodies, has been demonstrated not only among vertebrate species (McKenzie et al., 1982), but also between mammalian and arthropod (Drosophila) brains (Miller and Benzer, 1983).

Invasion of the nervous system has generally been viewed as a "dead end" for the virus, inconsequential to transmission or perpetuation in nature (Mims, 1977). There is evidence, however, that neurological infections may modify mosquito behavior. Aedes triseriatus mosquitoes infected with LaCrosse virus (a bunyavirus) exhibit enhanced probing responses during feeding (Grimstad et al., 1980), behavior that would favor horizontal transmission. Neurological infections of vertebrates are less likely to be adaptive to transmission, and most biological hosts involved in transmission cycles probably escape brain infections. The possibility that behavioral changes resulting from neurological infection of bat and rodent reservoir hosts of non-arthropod-borne flaviviruses may play a role in transmission patterns has, however, not been investigated.

\section{A. Host Factors That Influence Pathogenesis}

Flaviviruses produce a wide spectrum of infection and disease, depending on the specific virus-host pairing, virus dose, and multiple factors that influence host response (Fig. 2) (Albrecht, 1968; Nathanson, 1980). Three patterns of pathogenesis have been defined (Weiner et al., 1970; Nathanson, 1980): (1) fatal encephalitis usually preceded by early viremia and extensive extraneural replication; (2) subclinical encephalitis, usually preceded by low viremia, late establishment of brain infection, and clearance with minimal destructive pathology; and (3) inapparent infection, with trace viremia, limited extraneural replication, and no neuroinvasion. The role of immune responses in limiting viral dissemination has been repeatedly demonstrated in experiments employing immunosuppressive agents, which can convert subclinical to lethal encephalitis. In the case of virus-host pairs that result in fatal encephalitis, immunosuppression may prolong survival time, but does not alter outcome, indicating a potential pathogenic role for immune responses. A fourth pattern of flaviviral CNS infection will be discussed below, namely, chronic persistent infections. 


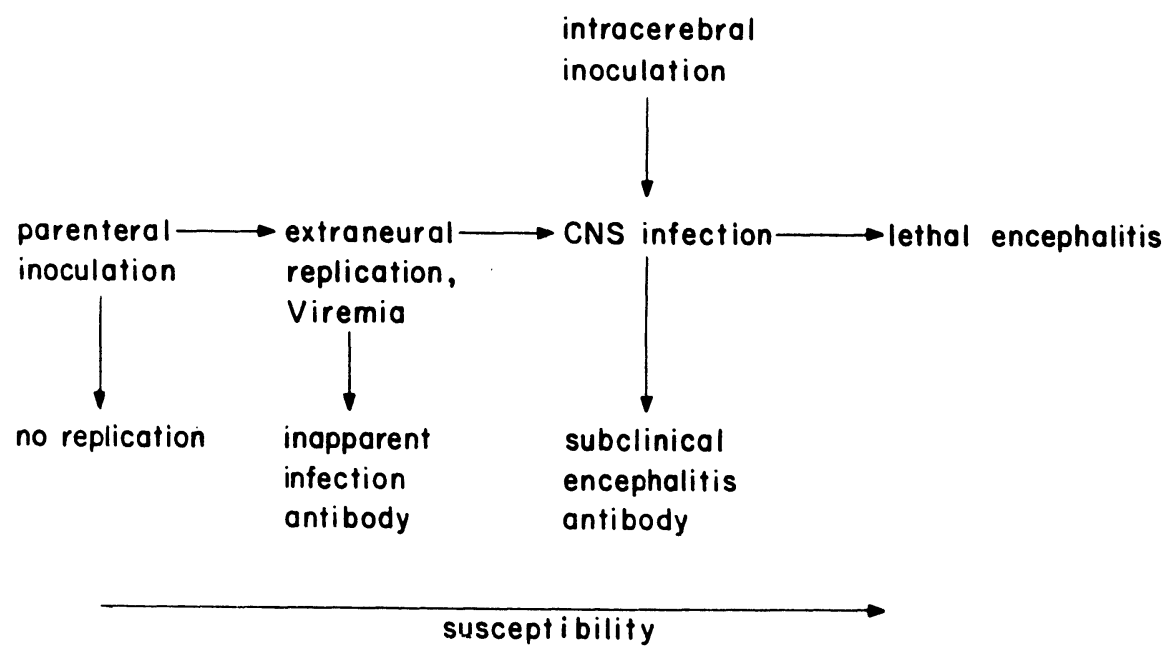

FIGURE 2. Spectrum of possible outcomes of neurotropic flavivirus infection.

\section{Age}

In general, neonatal or young animals are more susceptible to lethal encephalitis than older animals (O'Leary et al., 1942; MacDonald, 1952; Grossberg and Scherer, 1966). This is best exemplified in the case of virus strains of low or moderate virulence in laboratory mice or hamsters. Neonatal animals inoculated by the peripheral route are highly susceptible until 3-4 weeks of age, when resistance develops (El Dadah et al., 1967; Nathanson, 1980), but animals resistant by the peripheral route remain susceptible to lethal encephalitis when inoculated intracerebrally. Biological hosts also show age-related resistance to infection; nestling house sparrows infected with SLE (Bowen et al., 1980) and Rocio virus (Monath et al., 1978) develop viremias of longer duration and higher magnitude than adult birds.

Flaviviral infections in humans usually result in subclinical infection, the ratio of inapparent to apparent infection varying between 100 and 1000 to 1 , depending on age of the host. In distinct contrast to experimentally infected mice, human beings exposed during infancy or childhood to SLE and WN viruses usually experience inapparent or mild infections, and susceptibility to encephalitis increases with advancing age, the elderly being most severely affected (Fig. 3). JE virus has a biomodal age distribution, affecting both children and old persons (Kono and Kim, 1969). The mechanisms that underlie the increasing susceptibility with age are not known. Underlying diseases (hypertension, arteriosclerotic cerebrovascular disease, diabetes mellitus, alcoholism, and chronic bronchopulmonary disease) appear to be strongly associated with severity of SLE infection (Brinker and Monath, 1980), possibly reflecting reduced effectiveness of blood-brain barrier or immunological functions. 


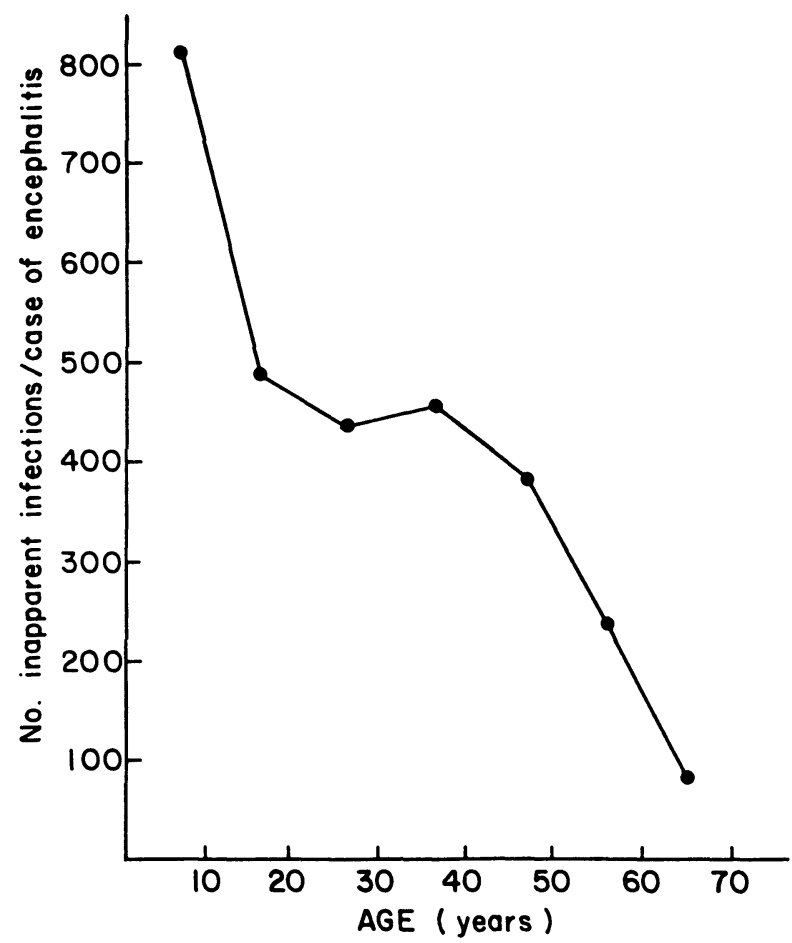

FIGURE 3. Increasing susceptibility of humans to neurological disease caused by St. Louis encephalitis virus with advancing age. Susceptibility is lowest in young children.

To the author's knowledge, the increased susceptibility to flaviviral encephalitis in the elderly has not been modeled in laboratory animals, although a single published observation suggests that it may occur (Zlotnik and Grant, 1976) (Fig. 4). Old hamsters showed increased susceptibility to Langat virus inoculated intranasally. This observation suggests the possibility of age-dependent changes at the level of the olfactory neuroepithelium.

\section{Genetic Factors}

Flavivirus-specific genetic resistance in mice, inherited as an autosomal dominant allele, is reviewed in Chapter 11. Although the molecular mechanisms are still unresolved, it appears from in vitro studies that resistance is associated with a greater production of defective interfering (DI) virus particles. Experiments with intact animals tend to support the concept that interfering virus production is involved in resistance. Early in infection of the congenic resistant mouse strain C3H/RV with Banzi virus, interfering virus appears in extraneural (lymphoreticular) tissues and is later amplified in the brain (A. Smith, 1981). Immunosuppression with cyclophosphamide, which converts an inapparent to a lethal Banzi 


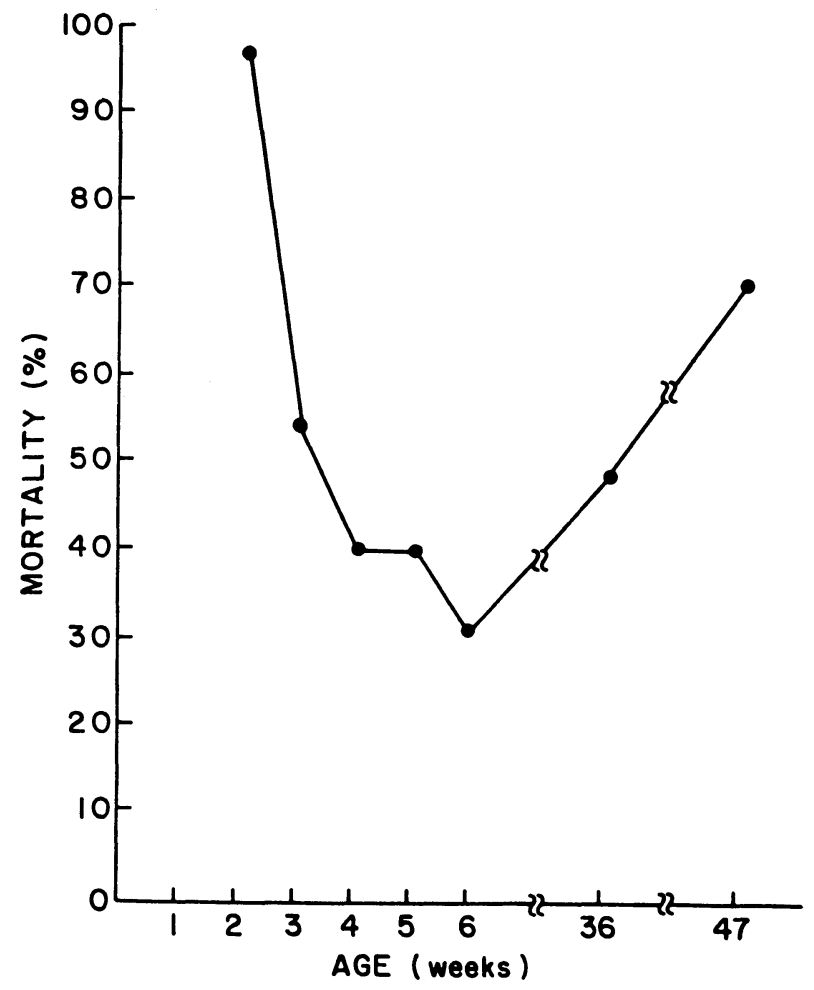

FIGURE 4. Relationship between age at inoculation and mortality in hamsters intranasally infected with Langat virus. The increased susceptibility of old hamsters is analogous to that seen in humans infected with SLE, WN, and JE viruses and may provide a model for study of the mechanisms involved. After Zlotnick and Grant (1976).

infection in RV mice (Bhatt and Jacoby, 1976), however, enhanced interfering virus production in the brain, indicating that immunological responses are essential to the expression of resistance. It is probable that in the intact $\mathrm{RV}$ animal, interfering virus production causes diminished extraneural viral replication and delayed neuroinvasion, allowing successful intervention of immunological responses.

As pointed out in Chapter 11, pathogenic viruses may be responsible for the selection of host resistance genes in nature and the evolution of stable host-virus relationships. The ecology of louping ill virus in Scotland exemplifies these phenomena. Woodland and forest species of birds (pheasants and capercaillie), which have had a long association with $I$. ricinus ticks and louping ill virus, have apparently developed resistance to infection, whereas moorland species (e.g., red grouse) are highly susceptible to lethal encepahlitis (Reid, 1975; Reid and Moss, 1980). The invasion of heather moorland by I. ricinus, and subsequent natural exposure of red grouse, is a recent development, coinciding with the de- 
velopment of sheep husbandry during the 19th century (Reid and Moss, 1980).

\section{Other Host Factors}

Andersen and Hanson (1974) showed that sexually mature female outbred mice demonstrated increased resistance to SLE virus compared to males; although a hormonal basis was suggested, neither pregnancy nor male castration altered resistance. Sex differences in susceptibility (as opposed to exposure to infected vectors) have not been reported in clinical hosts of flavivirus encephalitis.

Preexisting infections with unrelated agents have been shown to affect flavivirus pathogenesis. Several human cases of double infections with JE and herpes virus have been reported; doubly infected mice show colocalization of the two viruses, suggesting entry of JE viruses at sites of blood-brain barrier dysfunction caused by herpes virus infection (Hayashi and Arita, 1977). A similar mechanism may explain the increased susceptibility of mice to JE virus when dually infected with Trichinella spiralis (Cypress et al., 1973; Lubiniecki et al., 1974) or visceral larva migrans (Pavri et al., 1975). In a human autopsy study of JE patients in India, Shakar et al. (1983) noted an association between JE and neurocysticercosis. On the basis of finding high immunoglobulin E (IgE) levels in acute-phase sera from patients, Pavri et al. (1980) and Shaikh et al. (1983) have postulated that chronic or intercurrent helminthic infections may predispose to clinically expressed JE infection. However, high IgE levels were present only during the acute phase of JE and declined in convalescence. This observation as well as the association of high IgE levels with several other viral diseases, including dengue, influenza, and herpes virus infections, suggests an immunological basis rather than a relationship to intercurrent parasitic infestation.

Elevated body temperature may restrict replication or increase inactivation of some flavivirus strains and convert a lethal to a sublethal infection (Cole and Wisseman, 1969). In general, virus strains that exhibit thermolability and temperature sensitivity also exhibit reduced virulence. Avian hosts of flavivirus encephalitis viruses have body temperatures in excess of $40^{\circ} \mathrm{C}$ and thus select against thermolabile or ts mutants.

Poisoning by heavy metals, including arsenicals (Gainer and Pry, 1972), lead (Thind and Singh, 1977), and cadmium (Suzuki et al., 1981), potentiates flavivirus encephalitis in mice. The mechanisms involved are unknown; in the case of lead poisoning, interferon and antibody responses were suppressed and virus titers in extraneural tissues enhanced.

\section{B. Major Aspects of Pathogenesis}

\section{Extraneural Infection}

In natural infections with arthropod-borne flaviviruses, or following experimental intradermal or subcutaneous inoculation, virus first repli- 
cates in the inoculation site and in lymph nodes that drain the site (Albrecht, 1968). The specific cell types involved in replication of the inoculation site are unknown, but probably include smooth and striated muscle and connective tissue. The probing arthropod or needle deposits virus in both extravascular and intravascular spaces, and a brief viremia shower may result, followed within hours by release of virus from infected cells at the inoculation site and regional lymph nodes, seeding of other tissues, and appearance of a secondary viremia coincident with disseminated extraneural infection. In the case of TBE infection of sheep, virus is carried to the bloodstream by lymphatic channels (Malkova, 1960), but this pathway has not been examined in other models.

Knowledge of the main sites of flavivirus replication outside the CNS derives almost entirely from tissue titration and immunofluorescence studies on experimental animals (Albrecht, 1960, 1968; Huang and Wong, 1963; Kundin et al., 1963; Harrison et al., 1982). Principal sites are of meso-, endo-, and ectodermal origin, and include smooth and striated muscle, osteo- and chondroblasts, connective tissue, lymphoid and reticuloendothelial cells, epithelium, renal tubular epithelium, endocrine and exocrine glands, hair follicles and tooth pulp, adrenal medulla, and peripheral somatic and autonomic nerves. Viral antigen has been repeatedly demonstrated in the muscularis of arteries and arterioles and occasionally in capillary walls, but the contribution of vascular endothelium as a source of viremia (and invasion of the brain) remains uncertain.

In baby hamsters infected with SLE and Rocio viruses, pancreas and heart were the most severely affected organs. Cytopathological changes at the ultrastructural level were described by Harrison et al. (1980, 1982). In exocrine and endocrine areas of pancreas, virus particles, packed within secretory granules, are released by exocytosis. Virus production thus follows the same pathway as the cells' normal secretory products, a phenomenon also noted in mucus-secreting Bowman's gland cells in the olfactory epithelium (Monath et al., 1983 and Fig. 5). Infection of mammary glands and secretion of virus in milk of infected goats is an important mode of spread of TBE viruses (Gresikova, 1957; Woodall and Roz, 1977).

In the flavivirus-hamster model, myocardial degeneration and necrosis with productive viral infection of myocytes and endothelium of myocardial vessels were also prominent findings. Other target tissues included skeletal muscle and small intestinal lamina propria, muscularis mucosae, vascular endothelium, and parasympathetic ganglia.

Correlations are possible between these experimental infection models and the pathogenesis of infection in biological and clinical hosts. Interstitial myocarditis has been reported in a case of WN encephalitis (Albagai and Chaimoff, 1959), in pediatric human cases of JE (J. K. G. Webb and Pereira, 1956), and in horses and monkeys experimentally infected with JE virus (Miyake, 1964). A case of subacute thyroiditis was associated with SLE virus infection (Goldman et al., 1977), possibly in- 


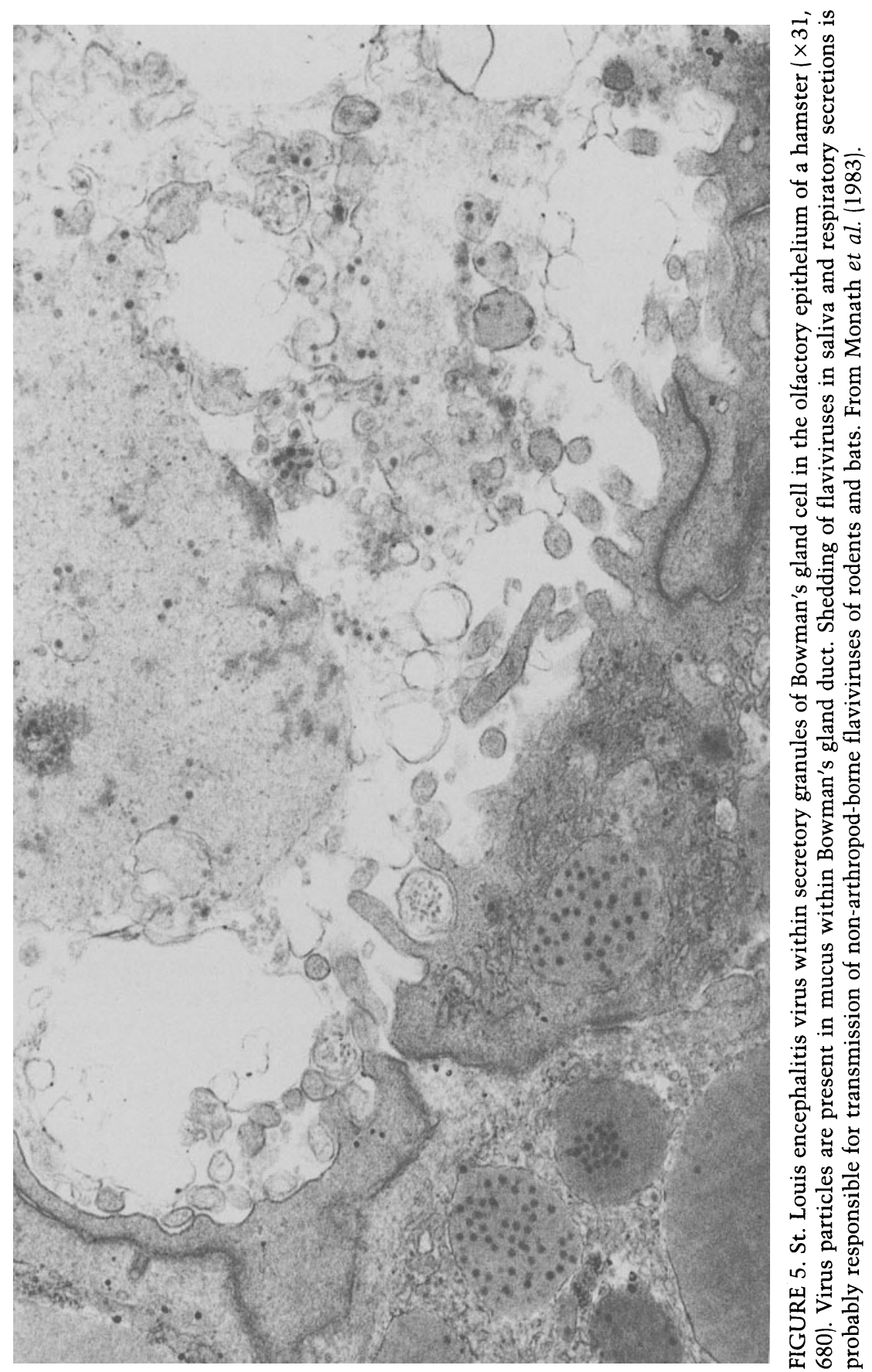


dicating viral tropism for endocrine glands in humans as well as in experimental animals. WN virus infection has been associated with pancreatitis in humans (Perelman and Stern, 1974).

\section{Viremia}

In biological hosts involved in transmission cycles, viremia, the result of vascular uptake of virus released from infected cells in extraneural tissues, reaches and is sustained at levels sufficient to infect arthropod vectors. In humans infected with TBE or WN virus, viremia is frequently detected during the acute phase, but this is not the case for the other flavivirus encephalitides, in which viremia is probably confined mainly to the incubation period. Viremia levels in clinical hosts are rarely if ever of a magnitude sufficient to infect arthropod vectors.

The level of viremia represents a balance among opposing forces of virus uptake into the bloodstream, virus clearance, and thermal inactivation. The decilife of Langat virus in the vascular compartment of Ateles monkeys was found to be $60 \mathrm{~min}$ (Nathanson and Harrington, 1967), and extravascular clearance by the reticuloendothelial system (rather than intravascular inactivation) was primarily responsible for disappearance.

Studies of nonimmune clearance of alphaviruses by hepatic sinusoidal cells have shown that avirulent strains were cleared from the circulation more rapidly than virulent strains (Jahrling and Sherer, 1973; Jahrling and Gorelkin, 1975; Jahrling, 1976) and that plasma clearance rates in vivo correlated with both increased affinity for cultured cells and $\mathrm{pH}$ attachment optima for macrophages near physiological $\mathrm{pH}$ (Marker and Jahrling, 1979). Clearance by macrophages of neurotropic flaviviruses is also an important determinant of the course of infection (Zisman et al., 1971; Monath and Borden, 1971; Olson et al., 1975). In contrast to the findings with alphaviruses, however, no difference was demonstrable in plasma clearance rates between virulent and avirulent strains of SLE virus in the mouse (Fig. 6), indicating that other factors (e.g., virus-induced macrophage killing, differential release from extraneural sites, or complement-mediated virolysis) are responsible for strain differences in viremia levels.

\section{Neuroinvasion}

Studies of experimental flavivirus encephalitis in mice have shown a relationship among level of viremia, development of brain infection (Weiner et al., 1970), and widespread or multisite simultaneous appearance of viral antigen in nervous tissue (Albrecht, 1960), supporting the concept of hematogenous spread to the CNS (Johnson, 1982). The process by which flavivirus particles cross the blood-brain barrier remains uncertain. The ability of these viruses to replicate in vascular endothelial cells suggests that they may infect and "grow across" capillaries in the 


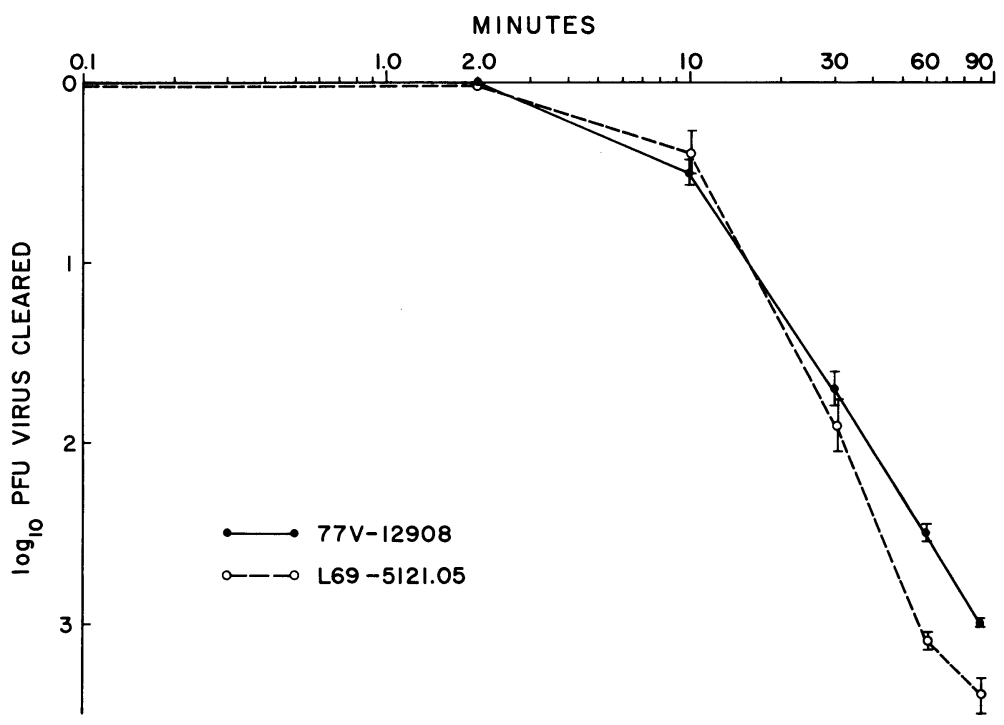

FIGURE 6. Clearance of virulent (77V-12908) and avirulent (L69-5121.05) St. Louis encephalitis virus strains from blood of weanling mice. Clearance rates do not differ significantly, indicating that other factors are responsible for the marked differences in height and duration of viremia between strains.

brain parenchyma. Viral antigen has been found only rarely in endothelial cells of brain capillaries by immunofluorescence or immunoperoxidase staining (Albrecht, 1968; Johnson et al., 1985), but the perivascular recruitment of immunologically specific inflammatory cells suggests that antigen presentation occurs at this level.

The olfactory tract has long been recognized as an alternative pathway to the CNS (Peck and Sabin, 1947) and an important mode of spread following aerosol exposure, but has been dismissed in naturally acquired infections. In a recent study, however, adult hamsters and weanling mice infected with SLE virus by the peripheral route showed a clear progression of infection from extraneural tissues to sensory neurons in the olfactory epithelium (Monath et al., 1983). Virus spread by axonal transport to the brain was documented by electron microscopy. There was no correlation between viremia and neuroinvasion. In this model, low (or undetectable) viremia, similar to levels that occur in human and equine hosts, results in infection of highly susceptible olfactory neurons, which are unprotected by a blood-brain barrier.

Dissemination of two SLE virus strains in weanling mice inoculated by the intraperitoneal route is compared in Fig. 7 . Both strains produce indistinguishable virus replication and lethal encephalitis when inoculated directly into the brain. After intraperitoneal inoculation, however, replication of the avirulent virus is markedly restricted and is found only rarely in olfactory epithelium or brain. The virulent virus invades the brain on day 5-6 by way of the olfactory epithelium and olfactory bulb. 


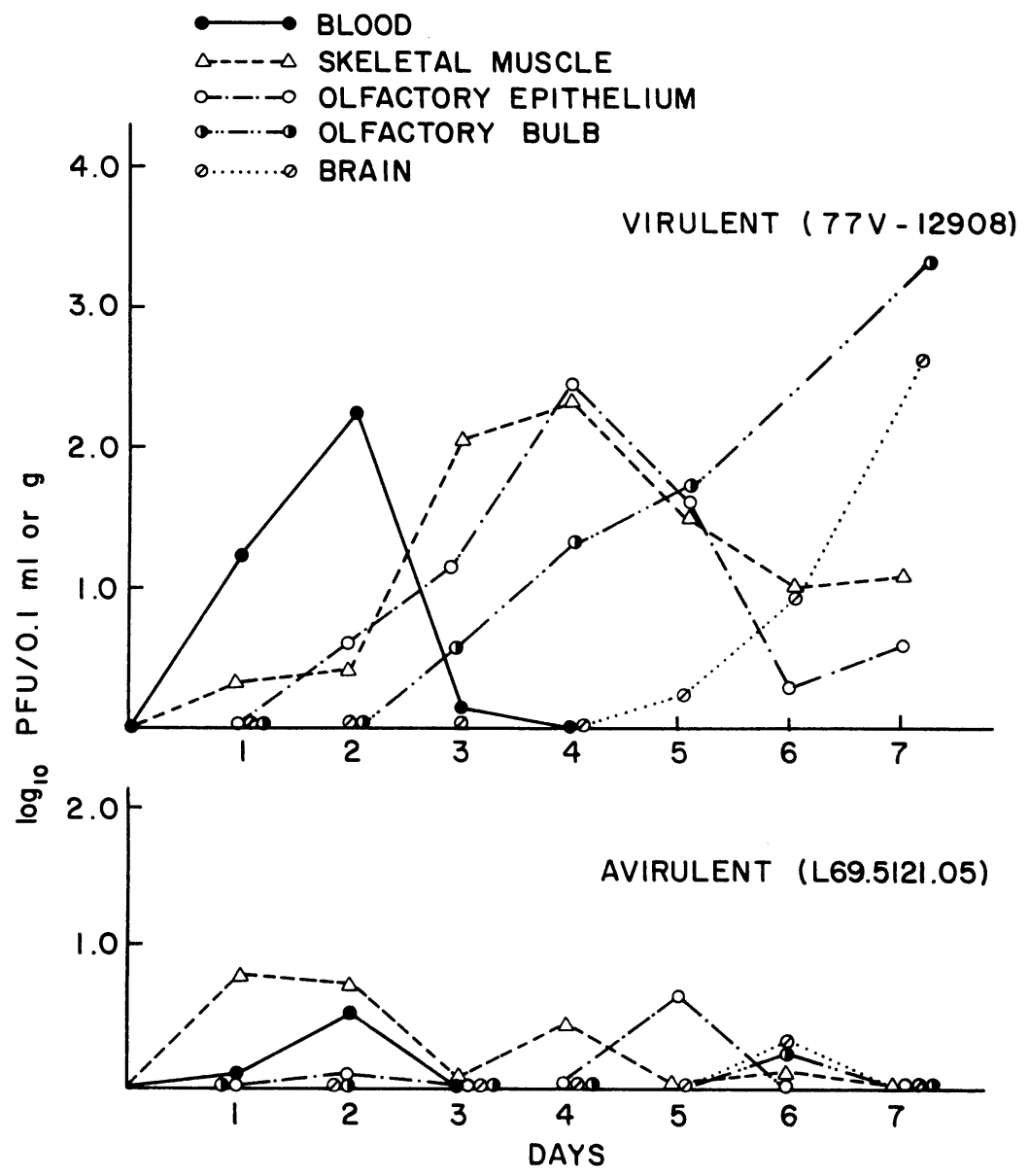

FIGURE 7. Sequence of infection of tissues in the mouse with two St. Louis encephalitis virus strains with different virulence. The olfactory neuroepithelium is infected early, in concert with extraneural tissues (e.g., skeletal muscle). Spread of virus is by axonal transport to the olfactory bulb.

The appearance of virus in olfactory epithelium parallels that in extraneural tissues (e.g., skeletal muscle), indicating absence of a barrier between blood and olfactory neural cells.

Few data are available on the routes of virus dissemination in humans. Embil et al. (1983) described an unusual case of Powassan virus infection that mimicked herpes encephalitis, having olfactory hallucinations and signs localizing to the temporal lobe. Sulkin et al. (1939) inoculated nasopharyngeal washings from SLE patients into mice and found evidence for subsequent immunity, but shedding of virus in the washings could have resulted from centrifugal (brain-to-olfactory-epithelium) spread of infection. Neuropathological lesions in the brains of humans are more extensive in thalamus, basal ganglia, and midbrain than 
in areas more proximal to the olfactory bulbs (Gardner and Reyes, 1980; Reyes et al., 1981). Johnson et al. (1985) studied JE antigen distribution and histopathological lesions in the brains of JE patients and found no predominance in olfactory bulbs. In one early infection, the only viral antigen detected was in the brainstem, leading the authors to conclude that viral invasion occurred from the bloodstream. However, similar findings are seen in monkeys intranasally inoculated with SLE and other flaviviruses (Zlotnik et al., 1970; Hambleton et al., 1983), indicating that selective vulnerability of neuronal centers, rather than routes of viral spread, determine neuropathological patterns.

Interestingly, the olfactory route of neuroinvasion has been demonstrated not only in rodent models but also in a natural avian host species, the house sparrow (T. P. Monath and C. B. Cropp, unpublished data). Birds peripherally inoculated with an SLE virus strain with intermediate virulence were found to have inconsistent, minimal viremias; all birds developed olfactory neuroepithelial infections on days $3-5$, but tissue titers were low. Brain infection followed on day 7-10 in only $5 \%$ of birds. Intracerebral inoculation of virus produced an asymptomatic, indolent infection with brain virus titers never exceeding 3-4 dex/g in $80 \%$ of birds; the remaining birds developed clinical encephalitis. Thus, in hosts with a low level of neuronal susceptibility, infection of olfactory epithelium may be terminated without establishment of brain infection.

\section{Pathological Changes in the Central Nervous System}

The extent, character, and distribution of lesions vary with host and virus strain. By light microscopy, inflammatory changes in meninges and along Virchow-Robin spaces of penetrating vessels are characterized by infiltration of lymphocytes, macrophages, and plasma cells. In the brain parenchyma, perivascular infiltrates surround small vessels and also contain mainly small lymphocytes as well as moderate numbers of histiocytes. Cellular aggregations or nodules in brain parenchyma consist of infiltrating mononuclear cells and possibly also activated resident microglial cells. Inflammatory changes may occur alone, or they may be accompanied by acute swelling, degeneration, and necrosis of neurons and neuronophagia. Endothelial-cell proliferation and necrosis, perineural and perivascular edema, spongy degeneration, and focal hemorrhages are evident in some models, e.g., mice infected with TBE virus (Vince and Grcevic, 1969).

In highly susceptible animals, such as the infant mouse, which succumbs rapidly to infection, inflammatory changes are often less striking than in more prolonged infections. In the infant mouse, changes at the light-microscopic level may be subtle at the time of death, but immunofluorescence and electron microscopy reveal extensive viral replication and ultrastructural cytopathology (Murphy et al., 1968).

In monkeys experimentally infected with a number of flaviviruses 
(Nathanson et al., 1966; Zlotnik et al., 1976; Monath et al., 1980b; Hambleton et al., 1983) and in fatal human cases (Haymaker and Sabin, 1947; Miyake, 1964; Rosemberg, 1977; Reyes et al., 1981), lesions are global in distribution but most prominent in gray matter of midbrain, thalamus, pons, cerebellum, and medulla. The selective vulnerability of these regions correlates with clinical manifestations (Gardner and Reyes, 1980). In some human cases, the constellation of clinical neurological findings allows relatively precise localization to brainstem, midbrain, or cerebellum (Estrin, 1976; Kaplan and Koveleski, 1978). The predominant involvement of thalamus, brainstem, and cerebellum explains the frequent occurrence of tremors, motor incoordination, and dystonia in these infections. The Far Eastern form of TBE is characterized by a predilection for damage to the medulla and cervical spinal cord, resulting in upper motor neuron paralysis of the shoulder girdle.

The comparative pathology of flaviviruses in various clinical hosts reveals interesting differences. Louping ill virus causes neuronal degeneration and inflammatory changes in brainstem and cerebellum of sheep, producing a characteristic ataxic disease (Doherty and Reid, 1971). In the red grouse, however, lesions localize in the forebrain and resemble those associated with eastern equine encephalitis in pheasants, possibly indicating a common avian response to viral injury (Buxton and Reid, 1975).

Horses with clinical encephalitis due to JE virus have distribution and character of neuropathology similar to humans (Sugawa et al., 1949; Miayake, 1964), whereas WN encephalitis in horses is characterized by a poliomyelitislike illness with prominent lesions restricted to the spinal cord (Guillon et al., 1968). The molecular basis for the selective vulnerability of neural subsets to viruses remains largely unknown (Johnson, 1980). The possible involvement of differences in virus-receptor interactions, particularly those involving neurotransmitter molecules, has been suggested (Tignor et al., 1984).

Residual neurological deficits, electroencephalographic changes (Lehtinen and Halonen, 1984), and psychiatric disturbances in humans frequently persist after recovery from acute encephalitis. Pathological descriptions of such cases have been few. Ishii et al. (1977) studied four cases with neurological residua 12-67 years after recovery from acute JE. Lesions were characterized by small areas of rarification, representing areas of neuronal loss, surrounded by dense microglial scarring, and distributed in areas typically affected during the acute phase.

Residual damage has been more difficult to assess in animal models. In mice, hindlimb paralysis occurs frequently during the acute phase, and such animals survive with this defect if saved from inanition. Changes in behavior and orientation, learning disabilities, and memory disorders have been documented in mice and rats infected with WN, Langat, yellow fever, and Murray Valley encephalitis viruses (Duffy et al., 1958; Duffy and Murphree, 1959; Seamer and Peto, 1969; Museteanu et al., 1979). Changes in catecholamine metabolism, implicated in behavioral abnor- 
malities with other viruses, have not been investigated in the case of the flaviviruses.

Demyelination, a feature of several alphavirus infections in rodent models (del Canto and Rabinowitz, 1982; Suckling et al., 1978; Sheahan et al., 1983), has not been described in experimental flaviviral infections. One reported human SLE case had clinical features resembling cranial nerve root demyelination as seen in Guillain-Barré syndrome (Sanders et al., 1953), but this has not been a typical feature of human flaviviral infections. Either oligodendrocytes are not targets for flaviviral replication or infection of neural cells with these viruses fails to initiate autoimmune injury. Subacute and chronic forms of encephalitis have been described in animals and humans, especially in association with tickborne flaviviruses. Louping ill in sheep and Far Eastern TBE in humans (Ogawa et al., 1973) may produce a subacute or chronic, progressive encephalitis. Hamsters given Langat virus by various routes (Zlotnik et al., 1973; Zlotnik and Grant, 1976) develop a subacute sclerosing disease characterized by typical inflammatory changes early on, followed by a progressive degeneration over 3 months with astrocytic proliferation, perivascular granulomatous infiltrates, and neuronal vacuolation. Chronic encephalitis with similar pathological lesions was found in monkeys surviving acute infection with tick-borne viruses (Ilienko et al., 1974; Zlotnik et al., 1976; Asher, 1979).

\section{Persistent and Congenital Infections}

TBE strains vary in their capacity to produce chronic encephalitis in monkeys, but apparently not in their ability to induce persistent infections (Ilienko et al., 1974; Pogodina et al., 1981a). In monkeys surviving encephalitis, virus was recovered for as long as 2 years (Pogodina et al., 1981a). Persistent infection was demonstrated after resolution of motor deficits in this study, but not in another (Asher, 1979). Some chronically infected animals had titers of $3-5 \mathrm{dex} / \mathrm{g}$ in brain homogenates; however, reactivation techniques (cocultivation with cells or explantation) were often required for recovery of virus, especially from visceral organs (Fokina et al., 1982). Among the latter, lymphoreticular tissues appeared to be especially important sites of latent infection, a strategy adopted by many other viruses to avoid immune elimination.

Relatively little is known, however, about the mechanisms involved in persistence in the intact host. Mice with chronic brain infections and paralysis due to Kyasanur Forest disease virus appear not to develop serum neutralizing antibodies (Price, 1966), again suggesting, in some model systems, a relationship between persistent virus infection and suppression of immune elimination. In support of this view is the demonstration that JE virus persists for prolonged periods in lymph nodes of athymic nude mice in the absence of clinical signs (Hotta et al., 1981a). Changes in phenotypic markers of strains recovered from chronically infected 
monkeys have been reported (Pogodina et al., 1981b). Some but not all strains exhibited reduced mouse neurovirulence or absence of hemagglutinating antigen or both. No information is available regarding temperature markers or DI properties of these strains.

Similar features have been described in intracerebrally and peripherally inoculated monkeys that developed asymptomatic or postencephalitic persistent infections with a variety of WN virus strains (Pogodina et al., 1983). Pathological changes in the CNS of persistently infected animals took the form of a subacute, progressive process with lesions at various stages of development indicating fresh, ongoing neuronal destruction as well as foci of reparation and scarring. A number of the persistently infected animals never developed neutralizing antibodies or reverted to seronegative. After $5 \frac{1}{2}$ months of persistence, virus recovered from tissues was avirulent for mice and noncytopathic in cell culture, but synthesized antigen detectable by immunofluorescence. The evidence suggests that multiple mechanisms may be involved in vivo, but generation of mutant viruses having characteristics associated with persistence in cell culture may occur (reviewed by Brinton, 1983). These observations raise concerns about the development of live attenuated vaccines against neurotropic flaviviruses and underscore the need to elucidate host- and virus-specified mechanisms that underlie persistence.

Viral persistence in vertebrate hosts has long attracted attention as one possible explanation for survival of viruses over periods adverse to transmission by arthropod vectors. Persistent infections with prolonged viremia or recrudescent viremia following arousal from hibernation have been demonstrated in bats infected with SLE and JE viruses (Sulkin and Allen, 1974), hedgehogs, dormice, and bats infected with TBE (Kozuch et al., 1963; Nosek et al., 1960), and snakes and lizards infected with JE virus (Lee, 1968; Doi et al., 1983).

Congenital infections with neurotropic flaviviruses are medically and ecologically important. In Asia, JE virus is an important cause of epizootic abortion and stillbirth in swine, which serve as major amplifying viremic hosts in nature. JE virus has also been isolated from brain, liver, and placental tissues of aborted human fetuses (Chaturvedi et al., 1980a). Transplacental infection of several neurotropic flaviviruses has been studied in mice, hamsters (Tamura et al., 1977), and bats (Sulkin et al., 1966). Congenitally infected progeny of SLE-virus-infected mice generally show minimal neuropathological lesions, but exhibit significant behavioral changes (Andersen and Hanson, 1970, 1975). Mice infected with JE virus show the highest frequency of resorption, stillbirth, and congenital malformations when inoculated 9-16 days before parturition (Sagamata and Miura, 1982). Mice have been shown to transmit JE virus to offspring of consecutive pregnancies (Mathur et al., 1982), and immune suppression during pregnancy has been postulated to play a role in establishment of persistent maternal infection in this model (Mathur et al., 1983a). 
Transplacental transmission in swine is not the only way in which reduced fertility is produced by JE virus. This agent has been suspected on epidemiological grounds to cause reduced libido and hypospermia in boars (Habu et al., 1977). Experimentally infected boars develop fever, viremia, and shedding of virus in sperm for up to 17 days. After recovery, they show defective spermatogenesis and testicular inflammatory histopathological changes (Ogasa et al., 1977). Artificial insemination with infected sperm resulted in viremia and lack of fertilization of recipient sows.

\section{Immune Responses}

Three general approaches have been used to characterize humoral and cell-mediated responses in neurotropic flavivirus infections: (1) direct measurement of the immune response or its in vitro correlates, using specimens taken at various times after infection; (2) additive studies, in which antibodies or cells from an immunized donor are passively transferred to a recipient host; and (3) subtractive studies, in which the course of viral infection in the host is altered by immunosuppression. Considerable attention has been focused on the role of immune responses in age-related and genetically controlled resistance in mice, on the pathological role of inflammation in the CNS, and on the role of suppressor T cells in the induction of persistent infections. Other specialized aspects of flaviviral immunity that have been studied include antibody-mediated enhancement of viral replication and the appearance of autoantibodies.

A schematic representation of the sequence of viral replication and immune responses that have been shown to occur in flaviviral encephalitis is shown in Fig. 8.

\section{Humoral Immunity in Animal Models}

In murine models of flaviviral encephalitis, hemagglutination-inhibiting $(\mathrm{HI})$ and neutralizing $(\mathrm{N})$ antibodies appear 4-6 days after peripheral inoculation of virus (H. E. Webb et al., 1968; Bhatt and Jacoby, 1976; Monath and Borden, 1971; A. L. Smith and Jacoby, 1986). Detection of antibodies is closely associated temporally with termination of viremia and appearance of virus in the brain. Serum antibodies with biological (HI, N) functions in both the IgM and IgG classes appear nearly simultaneously, but IgM antibodies predominate in the early phase of infection (H. E. Webb et al., 1968; Monath and Borden, 1971; Ishii et al., 1968). During a brief period of immune clearance, both antibodies and virus may cocirculate in blood. Measurements of antibody plaque-forming cells $(\mathrm{PFC})$ in mice infected with JE virus indicate initiation of a specific immune response in spleen as early as $24 \mathrm{hr}$ postinfection, reaching a peak 


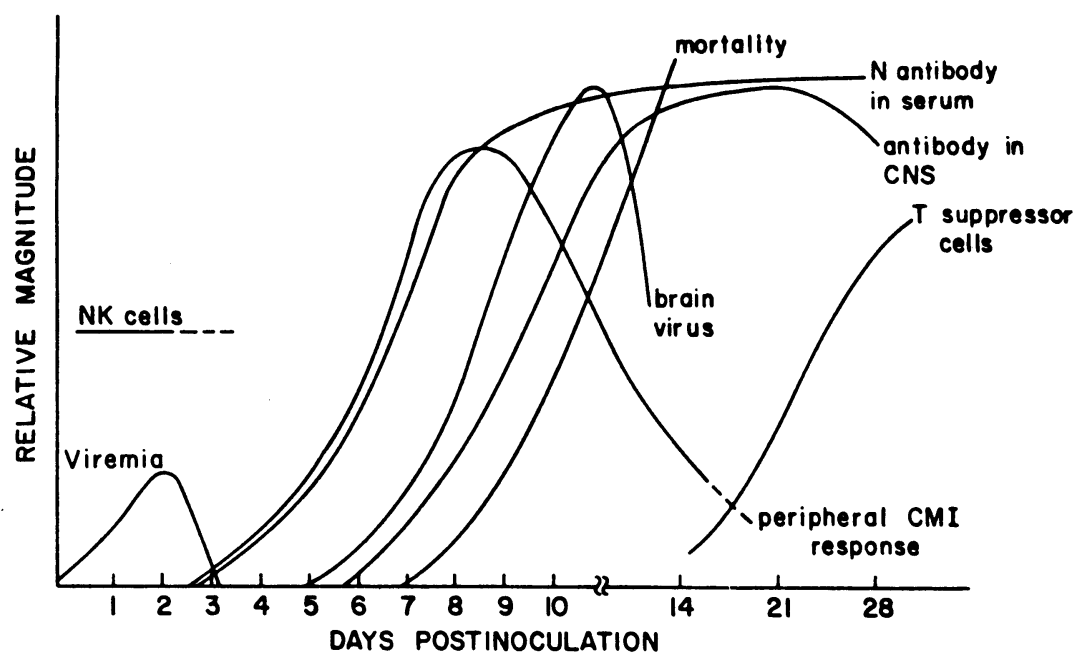

FIGURE 8. Schematic representation of course of viral replication and immune responses during infection with a neurotropic flavivirus. (NK cells) Natural killer cells. Peripheral cell-mediated immune (CMI) response includes delayed-type hypersensitivity, leukocytemigration inhibition, cell-mediated cytotoxicity, and adoptively transferable protection. CMI responses in the CNS probably occur later.

on day 5-6 coincident with detection of serum antibodies (Mathur et al., $1983 \mathrm{~b})$.

The consistency and timing of humoral responses to primary infection suggest that they play a major role in recovery. Survival of sheep infected with louping ill virus was shown to correlate with rapidity of the serum $N$ antibody response (Reid and Doherty, (1971). Studies of systemic and local CNS antibody responses in humans with JE have shown strong correlations between survival and both early and quantitatively strong antibody responses (Burke et al., 1985b,c). Patients who survived JE were found to have serum IgG antibodies during the first 5 days of illness, whereas fatal cases became seropositive later.

Administration of cyclophosphamide, which has a number of immunomodulating effects but primarily impairs the humoral antibody response, has been shown to potentiate flaviviral encephalitis (Bhatt and Jacoby, 1976; Camenga et al., 1974; Cole and Nathanson, 1968). Treated animals have higher and more persistent viremia, a progressive increase in brain virus titers and neuronal necrosis, and higher mortality ratios. Genetic resistance of $\mathrm{C} 3 \mathrm{H} / \mathrm{RV}$ mice to Banzi virus is abrogated by cyclophosphamide treatment (Bhatt and Jacoby, 1976).

The ability of passively administered antibody to confer protection has also been established (Hammon and Sather, 1973). Antibody transferred to mice as late as 6 days after peripheral inoculation with WN virus prevented lethal infection, even though brain infection had already been established (Camenga et al., 1974). Serum from donor mice taken 1 and 
2 weeks after infection protected recipients against lethal JE virus challenge given $24 \mathrm{hr}$ after antibody (Mathur et al., 1983b); the protective capacity of the serum was abolished by removal of IgM with 2mercapthoethanol.

Is antibody that appears during the critical early phase of infection effective in the recovery process? A. L. Smith and Jacoby (1986) compared the early immune responses of congenic flavivirus-susceptible $(\mathrm{C} 3 \mathrm{H} / \mathrm{He})$ and -resistant $(\mathrm{C} 3 \mathrm{H} / \mathrm{RV})$ mice. In this model, the mice succumb to parenteral Banzi virus infection on day 7-8, whereas RV mice develop on day 6 subclinical brain infection, which peaks on day 9 and then clears (Jacoby and Bhatt, 1976). N antibodies in serum are first detectable on day 5 or 6 in both RV and He mice, but antibody with capacity to protect adoptively immunized mice did not appear until day 10 postinfection. Protective capacity was associated with complement-dependent cytotoxicity for infected mouse neuroblastoma cells. These observations suggested that the appearance of protective and cytolytic antibody coincided with onset of viral clearance from the brain, but was not present early enough to be critically involved in the primary control of infection in resistant mice.

The biological role of $\mathrm{N}$ antibody and antibodies involved in cytotoxicity and antibody-dependent cell-mediated cytotoxicity (ADCC) reactions, as well as the viral proteins to which these antibodies are directed, require further investigation. Cytolysis of dengue-virus-infected Vero cells by complement and antibody was found to be relatively inefficient (Cantanzaro et al., 1974). Brandriss and Schlesinger (1984), however, have recently described protection of mice against encephalitis by complement-dependent cytotoxic antibodies directed against a nonstructural polypeptide (NV3) of yellow fever virus. Antibodies directed against nonstructural virus-specified proteins on the surface of infected cells appear relatively late, but probably play an important role in viral clearance. ADCC was not detected in a study of Banzi-virus-infected mice (A. L. Smith and Jacoby, 1986), but Kurane et al., (1984) demonstrated antibodydependent lysis of dengue-infected Raji cells by human peripheral-blood mononuclear cells. Although demonstrable in vitro, the biological significance of ADCC in vivo remains unknown.

\section{Cell-Mediated Immunity in Animal Models}

A role for cell-mediated immunity $(\mathrm{CMI})$ in primary flaviviral infection has been postulated on the basis of measurement of delayed-type hypersensitivity (DTH) responses, T-cell cytoxicity, in vitro correlates of CMI (leukocyte-migration inhibition), and immunosuppression-reconstitution experiments. Most studies have shown onset of CMI coincident with or shortly before the appearance of serum antibodies. In Banzi-virusinfected $\mathrm{C} 3 \mathrm{H} / \mathrm{RN}$ and He mice, T-cell immunity demonstrated by cytotoxicity assays with splenic (Sheets et al., 1979) or peritoneal exudate 
(A. L. Smith and Jacoby, 1986) effector cells appeared on day 6 after infection. Generation of cytotoxic $\mathrm{T}$ cells has also been demonstrated in mice infected with a member of the TBE complex (Gajdosova et al., 1981). In JE-virus-infected mice, transient antigen-specific leukocyte-migration inhibition was found beginning on day 3 and peaking on day 9 (Mathur et al., 1983b). CMI responses to dengue viruses were also investigated using this assay by P. S. Nagarkatti et al. (1978) and Chaturvedi et al. (1978). DTH responses determined by measuring inflammatory infiltration after footpad challenge have been demonstrated in mice infected with SLE (Hudson et al., 1979), JE (Mathur et al., 1983a), and dengue viruses (Pang et al., 1982). The maximum DTH response in these models occurred on day 6 and then rapidly declined; responses were enhanced by cyclophosphamide and splenectomy, probably by eliminating $T$ suppressor cells or their precursors. It should be emphasized that the CMI responses measured in these studies represent peripheral responses and that CMI in the CNS probably occurs later.

Selective depletion of $\mathrm{T}$ lymphoctyes with antiserum has been shown to potentiate flaviviral encephalitis, while prolonging survival time (see Section IV.C.4). Treatment with antithymocyte serum (Jacoby et al., 1980) or thymectomy (Bhatt and Jacoby, 1976) converted RV mice infected with Banzi virus to the susceptible phenotype. Susceptible He mice were protected after adoptive immunization with spleen cells (Jacoby et al., 1980); however, transfer of donor cells was effective only beginning 5-7 days after priming and only in recipient mice adoptively immunized within $24 \mathrm{hr}$ after virus challenge. Taken together, studies of the Banzi$\mathrm{C} 3 \mathrm{H}$ mouse model indicate that T-cell immunity (like humoral antibody) is required for recovery, playing a role in late viral clearance, but that other factors, such as production of DI virus (A. Smith, 1981)(see also Chapter 11), are critical early determinants of genetic resistance.

The contribution of CMI to recovery and protection from encephalitis induced by yellow fever and dengue viruses has been assessed using athymic nude mice (Bradish et al., 1980; Hotta et al., 1981a,b). The participation of $\mathrm{T}$ cells in determining the course and outcome of infection is influenced by the viral strain. Depending on the viral strain used, susceptibility to lethal infection may be enhanced or unaffected. Presumably, host defense mechanisms that are not T-cell-dependent (e.g., macrophages, IgM antibody) are sufficient to abort infection with viral strains of marginal neuroinvasiveness, whereas CMI, together with other responses, is required for clearance of more virulent viral strains.

Other cellular effector mechanisms that may play a role in flavivirus encephalitis include natural killer $(\mathrm{NK})$ cells and macrophages $(\mathrm{M} \phi)$. Cells with NK functions against virus-infected cells or NK-sensitive target-cell lines have been described in the case of Kunjin (McFarland and White, 1980), yellow fever (Fagraeus et al., 1982), and dengue (Kurane et al., 1984). The functions of $M \phi$ in flaviviral encephalitis are essentially unknown. Resistance of mice to encephalitis caused by yellow fever was abrogated 
TABLE VI. Permissiveness of Stimulated Mouse Peritoneal Macrophages for Two Strains of St. Louis Encephalitis Virus

\begin{tabular}{ccccc}
\hline & \multicolumn{4}{c}{ Yield $^{a}(\mathrm{PFU} / \mathrm{ml})$ in the presence of: } \\
\cline { 2 - 5 } Virus & TCF & NS & $77 \mathrm{~V}-12908$ Aby & L69-5121.05 Aby \\
\hline $\begin{array}{c}77 \mathrm{~V}-12908 \\
\text { (virulent) }\end{array}$ & $2.6 \pm 0.2$ & $2.6 \pm 0.2$ & $3.7 \pm 0.2$ & $2.4 \pm 0.2$ \\
$\begin{array}{c}\text { L69-5121.05 } \\
\text { (avirulent) }\end{array}$ & $1.8 \pm 0.2$ & $1.0 \pm 0.4$ & $3.6 \pm 0.2$ & $3.4 \pm 0.1$ \\
\hline
\end{tabular}

${ }^{a}$ Yield is expressed in plaque-forming units $(\mathrm{PFU}) / \mathrm{ml}$ at $72 \mathrm{hr}$ postinfection. (TCF) Tissue-culture fluid; (NS) normal serum.

by $M \phi$ blockade with silica (Zisman et al., 1971). Similarly, viral multiplication of SLE virus in mice was enhanced by treatment with thorotrast (Monath and Borden, 1971). These measures may have broad effects (e.g., on circulating monocytes and NK cells), and thus the role of nonspecific resistance of tissue $M \phi$ remains uncertain.

The intrinsic and extrinsic interactions of $M \phi$ with encephalitis viruses have received considerably less attention than those with dengue and yellow fever viruses. Infection of M $\phi$-like cell lines with TBE (Phillpotts et al., 1985) and with WN virus (Peiris and Porterfield, 1979; Cardosa et al., 1983; Gollins and Porterfield, 1984) has been studied in relation to antibody and complement-receptor-mediated enhancement of replication, but less is known about the role of $M \phi$ in vivo. Macrophages in the host are functionally diverse, as are primary $\mathrm{M} \phi$ obtained from animals by various techniques (bacille Calmette Guérin activation or thioglycollate-stimulated inflammation). The complexity of WN virus-M $\mathrm{M}$ interactions has been demonstrated recently by Cardosa et al., (1986), who found that permissiveness to virus growth varied with physiological state of $M \phi$, age and strain of mouse, and receptor pathway of virus entry. Other observations suggest a role for $\mathrm{M} \phi$ in determining outcome of infection with flaviviruses having different virulence characteristics. Thioglycollate-stimulated peritoneal $M \phi$ from 4-week-old mice were found to be relatively less permissive for an avirulent strain of SLE virus than for a virulent virus strain in the absence of antibody (Monath, unpublished data) (Table 6). Interestingly, homologous antibody-mediated enhancement of virus growth was demonstrated, but reciprocal heterologous enhancement occurred in one direction only, indicating heterogeneity of enhancing epitopes on SLE, as was found for dengue viruses (Halstead et al., 1984). The mechanisms involved in intrinsic resistance are not known, but might include interferon production or DI particles.

\section{Immune Response in Humans}

Relatively little is known about humoral and cellular immunity in human flaviviral encephalitis. As in experimentally infected mice, an- 
tibodies in humans are often detectable at the time of onset of neurological symptoms, and it has been rarely possible to study the chronology of immune responses that begin during the incubation period. Antibodies have been measured by standard assays (HI, N, complement-fixation, immunoassays) and have not been characterized by viral protein specificity or employed in cytotoxicity or ADCC assays. Several investigators have described the distribution of antibodies in the IgM and IgG classes in sera from cases of flavivirus encephalitis (Ishii et al., 1968; Burke et al., 1985c; Monath et al., 1984). Serum $\mathrm{N}$ antibody titers in convalescent sera from cases with overt CNS disease are usually higher than titers in persons who have sustained inapparent infections (Mayer et al., 1976; Chatuverdi et al., 1979), probably reflecting greater viral replication and antigenic stimulation in the former group. Antibodies are also locally produced in the CNS (see below). Recent studies of antibody responses in human cases of JE (Burke et al., 1985b,c) led to several important conclusions: (1) Persons sustaining inapparent infections do not develop local CNS antibody and thus have not experienced brain infection; (2) during the acute phase of infection, persons with fatal encephalitis have absent, low, or delayed levels of virus-specific IgM and IgG in serum and cerebrospinal fluid; whereas (3) patients with encephalitis who survive have vigorous and brisk systemic and local CNS antibody responses. These observations illustrate some of the dynamics of the "race" between humoral immune response, extraneural replication, and neuroinvasion. $\mathrm{T}$-cell responses in humans with TBE (Mayer et al., 1976; Sipos et al., 1981) and JE (Chaturvedi et al., 1979) have been reported.

\section{Immune Responses of the Central Nervous System: Role in Recovery and Pathogenesis}

Cellular and humoral immune responses within the CNS have been extensively studied in mice infected with an alphavirus (Sindbis) (McFarland et al., 1972; Griffin et al., 1983; Griffin, 1981; Moench and Griffin, 1984) (see also Chapter 8).

Although not well characterized, similar events are probably involved in immune clearance of flaviviruses from the brain. Local production of antibody had been demonstrated after louping ill virus infection in sheep (Reid et al., 1971), SLE in mouse (R. Bowen and T. Monath, unpublished data), and SLE (Ehrenkrantz et al., 1974), JE (Burke et al., 1985a), and TBE (Hofmann et al., 1979) virus infection in humans. During the acute phase of infection, an early and vigorous antibody response in the CNS is an important component of virus clearance and recovery (Burke et al., 1985b). High or persisting IgM antibody levels appear to correlate with the severity of the encephalitis and thus, presumably, with the amount of antigenic presentation (Ehrenkrantz et al., 1974; Edelman et al., 1976). However, Burke et al. (1985c) found local synthesis of IgM 
in the CNS of patients long after recovery from JE, raising the possibility of virus persistence.

The demonstration of high IgE levels in acute JE infections (Shaikh et al., 1983) raises the possibility that IgE-mediated release of histamine from sensitized mast cells may play a role in the CNS inflammatory response. Although not described for flaviviruses, other viruses are known to induce IgE (Perelmutter et al., 1978).

The cellular immune response in flavivirus encephalitis coincides with peak peripheral cytotoxic T-cell and DTH responses (Hudson et al., 1979). Kitamura et al. (1972) and Kitamura (1975) studied the fate of ${ }^{3} \mathrm{H}-$ labeled circulating mononuclear cells in mice with JE. Both perivascular infiltrates and brain parenchymal infiltrates, including the rod cells in glial nodules (usually believed to be activated resident microglial cells), were found to be of hematogenous origin. Adoptive transfer of immune spleen cells taken from mice at the peak of the cytotoxic T-cell response was shown to protect against challenge with Banzi (Jacoby et al., 1980) and JE viruses (Mathur et al., 1983b). Concanavalin A, which has a wide variety of potential effects on T-cell function, has been reported to protect against JE in mice (Kelkar, 1982).

Clearance of flaviviuses depends in part on recognition and destruction of infected cells by $\mathrm{T}$ effector cells in concert with activated macrophages. T helper cells, B cells, and antibodies also represent an important component of flavivirus clearance and recovery from primary infection. Passively transferred antibodies can abort flavivirus encephalitis even when given after neuroinvasion has occurred, whereas transfer of immune cells is not effective at this stage. Among other factors, diffusion of antibodies into the brain substance must be relatively more efficient than movement of cytotoxic $\mathrm{T}$ cells and macrophages.

Johnson et al. (1985) studied the cellular components of CNS inflammation in fatal human cases of JE. Their findings were similar in many respects in those in the Sindbis-mouse model (Moench and Griffin, 1984). At the time of death (3-9 days after onset), approximately $30-40 \%$ of cells in perivascular cuffs had T-cell markers, $5-10 \%$ were suppressor/ cytotoxic cells, $15-20 \%$ were macrophages, and $10 \%$ were B cells.

The role of interferon in flaviviral clearance has not been clearly defined. A protective effect of exogenously administered interferon has been demonstrated in mice challenged with JE virus (J.-L. Liu, 1972). However, no difference in interferon production or sensitivity has been found between genetically resistant and susceptible mice (Darnell and Koprowski, 1974). Interferon levels in serum and brain are highest in cases of severe infection or infection with virulent virus strains (Monath et al., $1980 \mathrm{~b}$ ) and thus reflect the extent of virus replication, rather than a component of the recovery process.

\section{Immunopathology}

Inflammatory responses engaged in viral clearance may also play a pathogenic role when they involve a target organ with critical tolerances 
such as the brain. A number of studies have shown prolongation of the mean time to death from flaviviral encephalitis in immunosuppressed animals (Hirsch and Murphy, 1967; H. E. Webb et al., 1968; Camenga et al., 1974; Camenga and Nathanson, 1975; Semenov et al., 1975; Jacoby et al., 1980). The pathological role of the cellular immune response varies with virus-host pairing and also, probably, with the degree of expression of viral antigens on critical neuronal targets for antibody- or T-cell-mediated cytotoxicity or $\mathrm{M \phi}$-mediated ADCC. Thus, immunosuppression reduced inflammation in both WN and Langat encephalitis of mice, but prolonged survival of Langat-virus-infected mice only (Camenga and $\mathrm{Na}$ thanson, 1975). Moreover, high grades of inflammation may occur without producing symptomatology (Zlotnik et al., 1970; Reid et al., 1982).

Another potential immunopathological mechanism is antibody- (or complement-) mediated enhancement of viral replication in $\mathrm{M} \phi$. Although demonstrated in vitro with a number of flaviviruses (Peiris and Porterfield, 1979) and an important component of host responses to dengue viruses (see Section V.6), there is as yet no evidence for a role in the pathobiology of encephalitis. Antibody-mediated enhancement requires monocytes/macrophages bearing $\mathrm{Fc}$ receptors and noncytophilic, nonneutralizing antiviral type-specific or cross-reactive IgG antibodies [or CR3 receptors and complement (Cardosa et al., 1983)]. In the case of flaviviral encephalitis, nonneutralizing antibody from a prior heterologous virus infection could enhance extraneural replication and increase the risk of neuroinvasion. Against this possibility is the allopatric distribution of most members of the TBE group and the SLE-JE-WN-Murray Valley encephalitis complex, making sequential heterologous infections unusual events. The one common sympatric heterologous infection /dengue) appears to cross-protect against SLE and JE, rather than to enhance these infections (Bond, 1969; Tarr and Hammon, 1974; Edelman et al., 1975a). This observation is supported by a study showing lack of immune enhancement of dengue infection by JE virus antibodies (Putvatana et al., 1984).

Whether nonneutralizing antibodies produced early in the immune response to primary infection could enhance virus replication in vivo is not known; this does not appear to play a major role, however, in dengue, an infection that utilizes $M \phi$ as cellular targets for replication to a much greater extent than the encephalitis viruses.

\section{Suppressor-T-Cell Functions and Viral Persistence}

As with all other balanced biological reactions in vivo, mechanisms exist to regulate or suppress the immune response. Generation of suppressor cells was demonstrated in JE-virus-infected mice, both in vitro and by adoptive transfer of spleen cells (Mathur et al., 1983c, 1984). The ability of antigen-specific $\mathrm{T}$ lymphocytes from JE-virus-primed mice to suppress DTH responses and IgM antibody plaque formation against JE 
virus in spleen appeared 18 days after priming and persisted for 6 weeks. The suppressor $\mathrm{T}$ cells are cyclophosphamide-sensitive and mediate suppression through soluble products (Mathur et al., 1984). These findings correlated with previous reports (Mathur et al., 1983a,b) showing disappearance of CMI and protective antibodies after the 3rd week.

Pregnant mice develop persistent JE virus infections, which are reactivated during a consecutive pregnancy with transplacental infection of the fetus (Mathur et al., 1982). Pregnant mice had markedly impaired DTH and delayed but preserved leukocyte-migration inhibition responses to JE virus (Mathur et al., 1983a). Congenitally infected offspring had reduced T-cell populations in their spleens and impaired CMI responses to JE and to unrelated antigens (sheep erythrocytes). These observations suggest that impaired immune responses early in pregnancy followed by the appearance of $\mathrm{T}$ suppressor cells may be responsible for establishment and maintenance of persistent infection in this model. Impaired viral clearance by CMI mechanisms is similarly responsible for the persistence of JE viral infections in athymic nude mice (Hotta et al., 1981a).

\section{Protection from Subsequent Infection and Heterologous Cross- Immunity}

Long-lasting immunity follows infection with flaviviruses; even in long-lived species, protection from disease is assumed to be lifelong, although this may not always be the case (Ishii et al., 1968). Reexposure results in a rapid anamnestic humoral antibody response and quenching of viremia. A number of studies have demonstrated the protective capacity of antibodies passively administered before challenge (Lubiniecki et al., 1973).

Animals immunized by the peripheral route and then challenged intracerebrally may or may not be protected. In one study, passive administration of IgG antibodies was effective in protecting against lethal intracerebral challenge, whereas adoptive transfer of immune spleen cells was not (Chaturvedi et al., 1978). In contrast, protection from intracerebral challenge is complete in animals that have survived a prior brain infection, indicating local immunological memory in the CNS (Gerhard and Koprowski, 1977). This observation raises the potential problem of immunizing arbovirus laboratory workers against aerosol (olfactory route) exposure, especially with inactivated vaccines.

Cellular mechanisms are also involved in defense against subsequent challenge. It is not established whether intrinsic resistance of $\mathrm{M} \phi$ to flaviviruses increases after immunization. The growth of $\mathrm{WN}$ and yellow fever viruses was reduced in organ cultures of meninges from immunized mice (Rubenstein et al., 1972), an effect possibly mediated by $\mathrm{M} \phi$ and immune interferon. Cell-mediated responses are probably important in containing and eliminating infection after reexposure, since virus replication occurs at the site of inoculation and in regional lymph nodes (Mal- 
TABLE VII. Comparative Features of the Pathobiology of Dengue, Yellow Fever, and Wesselsbron Disease ${ }^{a}$

\begin{tabular}{lccc}
\hline & DHF/DSS & Yellow fever & Wesselsbron \\
\hline Hepatitis & +++ & +++ & +++ \\
Lymphoid, hyperplasia, necrosis & +++ & ++ & +++ \\
Myocarditis & + & ++ & + \\
Hemorrhagic diathesis & +++ & +++ & ++ \\
$\begin{array}{l}\text { Increased capillary permeability, } \\
\text { shock }\end{array}$ & +++ & +++ & ++ \\
$\begin{array}{l}\text { Complement consumption } \\
\begin{array}{l}\text { Renal pathology } \\
\text { Encephalitis }\end{array}\end{array}$ & +++ & + & $?$ \\
$\begin{array}{l}\text { Congenital malformation, } \\
\text { abortion }\end{array}$ & + & ++ & ++ \\
\hline
\end{tabular}

a (?) Not studied; $(0)$ absent; $(+)$ reported; $(++)$ frequent $_{j}(+++)$ constant feature.

${ }^{b}$ Reports of abortion and birth defects associated with classic dengue in the older literature have not been substantiated (Mirovsky et al., 1962).

kova and Kolman, 1964). As measured by DTH, leukocyte-migration inhibition, and adoptive transfer of cells, CMI responses are relatively shortlived after primary infection (Mathur et al., 1983b), but memory functions and secondary CMI responses have not been studied.

Heterologous cross-protection among flaviviruses has been extensively investigated (Vorndam, 1980), and its molecular basis has been explored using monoclonal antibodies (Roehrig et al., 1983). While antibodies appear to play the principal role in cross-protection, cellular immunity and interference phenomena may also be involved. Cross-reactivity between Langat and yellow fever viruses was found in a T-cell cytotoxicity assay (Gajdosova et al., 1980).

Significant protection against intracerebral challenge with Langat and WN viruses has even been reported to follow intracerebral immunization with alphaviruses (Oaten et al., 1976, 1980). The interference mechanism is unclear, but cross-immunity to host brain-cell glycolipid antigens incorporated into viral envelope (H. E. Webb et al., 1984) may be involved.

\section{PATHOGENESIS OF FLAVIVIRAL HEMORRHAGIC FEVERS}

Three mosquito-borne viruses, dengue, yellow fever (YF), and Wesselsbron (WSL), share certain pathogenetic features and are compared in this section and in Table VII. The emphasis will be on dengue hemorrhagic fever (DHF) and its most severe form, dengue shock syndrome (DSS), which have been shown, largely by Halstead and his collaborators, to have a unique immunopathological basis: antibody enhancement of viral infection (Halstead, 1980). 
DHF/DSS, an epidemic disease that principally affects children, is distinguished from classic dengue fever by the presence of $(1)$ increased vascular permeability with hemoconcentration, hypovolemia, hypotension, and serous effusions; (2) a bleeding diathesis of complex etiology, but always accompanied by thrombocytopenia, usually mild, but in about $5-10 \%$ of cases causing significant hemorrhage into skin, gastrointestinal tract, or urine; (3) hepatic enlargement and dysfunction of mild degree; (4) activation of the complement system; and (5) depletion or necrosis of lymphoid tissues. The case fatality ratio in untreated cases with shock is approximately $10 \%$, but early recognition and correction of hypovolemia significantly reduce the lethality. Myocarditis has been reported as a complication of dengue infection.

YF is an endemic and epidemic disease of humans and some species of monkeys characterized in its severe form by: (1) marked hepatic necrosis, dysfunction, and jaundice; (2) a bleeding diathesis, often with severe gastrointestinal hemorrhage; (3) vascular collapse and shock; (4) albuminuria and renal impairment; (5) depletion or necrosis of lymphoid tissues; and (6) myocarditis. The case fatality ratio is approximately $20 \%$.

WSL virus causes disease in sheep (principally newborn lambs) characterized by fever, severe hepatic necrosis and jaundice, hemorrhagic manifestations, myocarditis, signs of increased vascular permeability, and lymphoid necrosis. Mortality in experimentally infected lambs is as high as $30 \%$. Maternal deaths occur in pregnant ewes and abortion and congenital neurological defects in fetuses (Coetzer and Barnard, 1977). WSL virus generally causes a mild, febrile illness in calves, but occasionally a more severe infection resembling the disease in lambs (Blackburn and Swanepoel, 1980).

\section{A. Comparative Pathology}

The pathological manifestations in fatal cases of DHF/DSS are relatively unimpressive and generally insufficient to explain death. Whereas YF cases manifest more extensive pathology in at least one vital organ (liver), the immediate cause of death is also not clear and probably reflects a metabolic disturbance rather than "organ failure." Gross autopsy findings in DHF/DSS, YF, and WSL disease include hepatic enlargement or altered appearance, serous effusions, edema, and hemorrhages. The latter are usually of minor degree in DHF/DSS, but prominent gastrointestinal hemorrhage, similar to that seen frequently in human YF and ovine WSL disease (LeRoux, 1959), has been increasingly emphasized in some reports (Sumarmo et al., 1983; Guzman et al., 1984). Morphological evidence of disseminated intravascular coagulation (intravascular thrombi) has been rarely recognized in DHF/DSS (Fresh et al., 1969) and is not reported in YF or WSL. Skin biopsies from DHF patients with rashes show evidence of microvascular damage, with swelling and occasional necrosis of en- 
dothelial cells and perivascular edema and infiltration of mononuclear leukocytes (Boonpucknavig et al., 1979a,b). Similar lesions are inconsistently seen in other tissues from fatal cases.

At the microscopic level, the principal changes in DHF/DSS affect the liver, bone marrow, lymphoid organs, heart, lungs, and kidneys (Bhamarapravati et al., 1967). Lesions in the liver resemble the early phase of experimental YF in the rhesus monkey (Bearcroft, 1957; Tigertt et al., 1960; Monath et al., 1981), in which hepatocellular necrosis is minimal, and include hypertrophy and necrosis of Kupffer cells, central or paracentral focal coagulative necrosis of hepatocytes, Councilman bodies, and mild fatty metamorphosis. The pathology of fatal YF is qualitatively similar to DHF/DSS, but with much more severe and extensive hepatocellular necrosis (Ishak et al., 1982). Typically, a ring of preserved hepatocytes, one to two cells thick, surrounds the central veins and portal areas, and the distribution of necrosis can be described as "midzonal." In fatal human YF, the proportion of the liver lobule actually necrosed varies from 5 to $100 \%$, with a mean of $80 \%$ (Klotz and Belt, 1930). In dengue and YF, inflammatory changes are minimal. Cholestasis of mild to moderate degree may be present in YF, especially after the 8th day of illness (Camain and Lambert, 1966), but bile-duct proliferation is not observed. Recovery is associated with granulomatous changes and rapid regeneration of hepatocytes. Prolonged hyperbilirubinemia has been noted in some cases (Elton et al., 1955); the contribution of underlying chronic liver disease in such cases must be considered (Francis et al., 1972).

The liver pathology of WSL disease in lambs (LeRoux, 1959; Coetzer et al., 1978; Coetzer and Theodoridis, 1982) is characterized by diffusely scattered necrosis of individual hepatocytes, Councilman bodies, Kupffer cell proliferation, fatty infiltration, and cholestasis. In contrast to YF and dengue, infiltration of leukocytes is more prominent and there is proliferation of bile ducts.

In cases of DHF/DSS, the bone marrow shows increased cellularity and megakaryocytic arrest (Bierman and Nelson, 1965). Marked changes are evident in thymus and T-cell-dependent areas of nodes and spleen, including lymphocytolysis in the cortex of the thymus, germinal centers of lymph nodes, and splenic white pulp, phagocytosis of lymphoctes, and hyperplasia of reticulum cells and plasmacytoid cells (Bhamarapravati et al., 1967; Aung-Khin et al., 1975). Similar changes have been described in YF-infected monkeys (Monath et al., 1981) (Fig. 9) and in sheep with WSL virus disease (Coetzer and Theodoridis, 1982).

A transient proliferative glomerulonephritis due to deposition of immune complexes has been found in renal biopsies from DHF patients (Boonpucknavig et al., 1976a). Glomerular lesions in YF, consisting of Schiff-positive alteration in the basement membrane, have been associated with the marked proteinuria in this disease (Barbareschi, 1957). Deposition of immune complexes in kidneys has not been studied in YF, but in comparison with dengue would not be expected to play an im- 


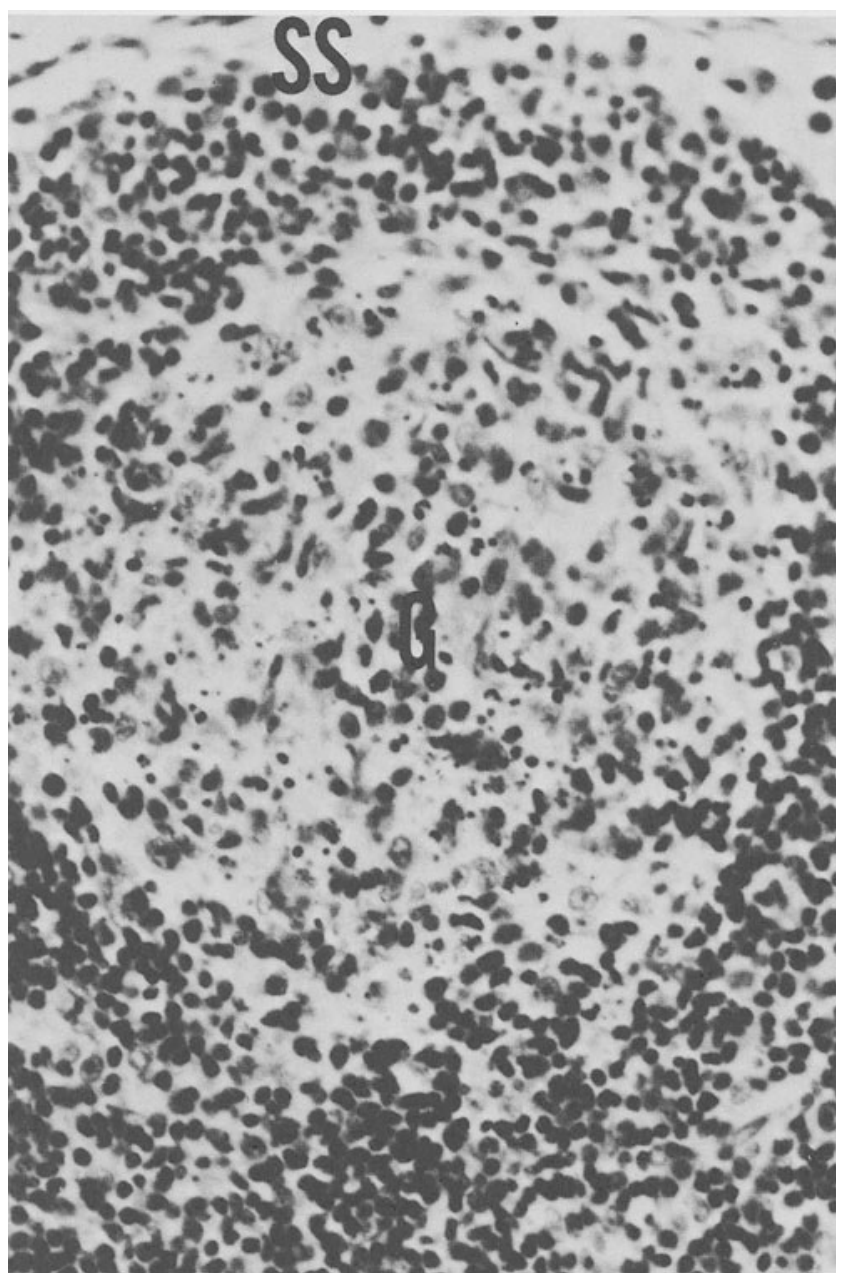

FIGURE 9. Necrosis of germinal center (G) of mesenteric lymph node of a rhesus monkey 6 days after inoculation of yellow fever virus. (SS), subcapsular sinus. From Monath et al. (1981).

portant role. Tubular epithelial changes in YF are more severe than in dengue and appear to represent a progression of shock and prerenal failure to acute tubular necrosis (Monath et al., 1981). Why this complication occurs in YF but not in DHF/DSS is unclear, but it may relate to the severity of hepatic necrosis in YF and the attendant hemodynamic changes affecting renal function. No renal pathology has been reported in WSL disease.

Hyaline degeneration, vacuolation, and necrosis of myocardial fibers, only rarely associated with mononuclear-cell infiltration, have been described in DHF/DSS (Bhamarapravati et al., 1967), YF (Lloyd, 1931), and WSL (Coetzer and Theodoridis, 1982). Cardiac muscle is probably a site 
of viral replication and pathological lesions the result of direct viral injury. Myocardial injury, bradyarrhythmia, and diminished cardiac output may contribute to the shock state in these infections.

\section{B. Sites of Viral Replication}

In dengue, the role of mononuclear phagocytes as target cells and principal sites of replication seems established (Halstead, 1980). Antigen has been detected in the cytoplasm of mononuclear leukocytes in skin (Boonpucknavig et al., 1979b), in spleen (Bhamarapravati and Boonpucknavig, 1966), and in lymph nodes, hepatic sinusoids, alveolae, and thymic cortex (Bhamarapravati, 1981). Denguelike viral particles have been demonstrated in renal glomerular M $\phi$ (Boonpucknavig et al., 1976a). Dengue viral antigen was demonstrated on the surface of unfixed circulating $B$ lymphocytes of DHF patients (Boonpucknavig et al., 1976b), but attachment of virus vs. replication in these cells was not differentiated. Scott et al. reported isolation of dengue viruses from peripheral-blood leukocytes (mainly glass-adherent monocytes) from DHF patients.

The tropism of dengue viruses for mononuclear leukocytes is supported by experimental infections of monkeys (Marchette et al., 1973) and further clarified by a number of in vitro studies (Halstead et al., 1973a, 1976, 1977; Theofilopoulos et al., 1976). In monkeys, virus replication increased progressively in lymphoid tissues and leukocytes and peaked at the time viremia was terminated, corresponding to the onset of shock in DHF/DSS patients. There was also evidence for viral replication in sites favored by other flaviviruses /skeletal and smooth muscle, salivary gland, adrenal gland). Increased levels of serum acid phosphatase of osteoclast origin in human patients (Lam et al., 1982) suggest that these cells may also be targets of viral replication or injury and are consistent with the bone pain associated with the disease.

Sequential histopathological and immunofluorescence studies of monkeys infected with YF virus have shown the earliest lesions and antigen in Kupffer cells in the liver and in scattered reticuloendothelial cells in lymph nodes and spleen (Tigertt et al., 1960; Monath et al., 1981). Infection of hepatocytes follows, but widespread necrosis is a late event in the rhesus monkey model, occurring during the last 1-2 days before death. Although far from complete, the available data suggest certain parallel features with DHF/DSS: (1) early infection of mononuclear phagocytes (of which Kupffer cells appear most important as a gateway of spread to the hepatic parencyhyma); (2) lymphoid organs, including lymph nodes and spleen, are sites of viral growth and in late stages of infection show necrosis of germinal centers and reticulum-cell hyperplasia ; (3) the onset of clinical symptoms (jaundice, oliguria, hypotension) coincides with the beginning of viral clearance from blood and tissues; (4) virus persists in tissues after clearance of viremia. Both antibody and 
virus (and thus presumably immune complexes) have been demonstrated in the sera of human YF patients in the course of the disease (World Health Organization, 1971). These observations taken together suggest that immune clearance of intracellular virus and, possibly, the formation of immune complexes may play a pathogenic role in human YF as in DHF/ DSS. However, the very rapid course of infection in the rhesus monkey model culminating in death only 5 or 6 days after inoculation, as well as the virtual absence of inflammatory lesions in YF, indicate that direct viral injury and secondary physiological effects of injury rather than immunopathological mechanisms are predominant events in this disease.

The experimental pathology of WSL virus has been described in sheep, cattle, and goats (Coetzer et al., 1978; Coetzer and Theodoridis, 1982; Blackburn and Swanepoel, 1980), but virological studies to define sites of virus replication have not been reported. On the basis of the pathological lesions, liver, heart, and possibly lymphoid tissues may be implicated as sites of viral replication. WSL virus is also clearly neurotropic in the ovine and bovine fetus. Both wild virus and live attenuated vaccine strains cross the placenta and produce neurological infection and malformations, including hydranencephaly and arthrogryposis (Coetzer and Barnard, 1977).

In mice, dengue, YF, and WSL viruses cause primarily encephalitic infections and have pathogeneses similar to those of other neurotropic flaviviruses. A spectrum of neurotropism is evident among the three agents: Wild strains of dengue virus often require sequential passage in mouse brain before full expression of neurovirulence (reviewed by R. W. Schlesinger, 1977, 1980), whereas unadapted YF strains do not. Age-dependent resistance to encephalitic infection develops in mice to parenteral inoculation of both dengue and YF viruses, whereas adult mice remain susceptible to WSL virus. Although not extensively studied, the extraneural sites of replication of these viruses in the mouse appear similar to other flaviviruses and include lymph nodes, spleen, and cardiac and skeletal muscle (Hotta et al., 1981a,b; David-West, 1975). Dengueinfected $n u / n u$ and $n u /+$ mice develop infection (demonstrated by immunofluorescence) and acidophilic hyaline necrosis of Kupffer cells without evidence for progression to hepatocellular infection (Hotta et al., $1981 \mathrm{~b}$ ), and suckling mice infected with YF virus may show focal degeneration of liver cells (David-West and Smith, 1971); in these models, however, the brain is the eventual principal target organ for viral growth and pathogenesis. The only lower mammal that manifests a viscerotropic response to YF virus similar to monkeys and humans is the European hedgehog (Erinaceus europeaus) (Findlay and Clarke, 1934). Boonpucknavig et al. (1981) studied the course of clinically inapparent dengue viral infection of adult outbred mice inoculated by the intraperitoneal route. Virus could not be isolated from tissues, but viral antigen was found by immunofluorescence in mononuclear leukocytes as late as 3 weeks after 
inoculation. Evidence was obtained for immune-complex deposition and proliferative glomerulonephritis, analagous to that described in humans with DHF (Boonpucknavig et al., 1976a).

The neurotropism of dengue and YF viruses must also be considered with respect to primate hosts. Dengue virus strains require adaptation by mouse-brain passage to become neurovirulent for monkeys, whereas unadapted YF viruses exhibit a higher degree of neurovirulence. Rhesus monkeys inoculated by the intracerebral route succumb to typical viscerotropic YF unless protected by immune serum, in which case they die of encephalitis (Theiler, 1951). Nevertheless, human cases of encephalitis due to YF virus are very unusual, and only a single case of naturally acquired YF encephalitis has been reported (Stefanopoulo and Mollaret, 1934). Post vaccinal encephalitis was a relatively frequent complication of children with the French neurotropic strain (LeMercier et al., 1966). Neuroinvasion by $17 \mathrm{D}$ vaccine, which exhibits reduced neurovirulence for monkeys is, however, very unusual in humans, and cases have been limited to infants and young children. This suggests that in this age group, encephalitis may be a heretofore unrecognized complication of infection with wild YF virus strains. Signs of CNS dysfunction, including stupor, coma, hyperexcitability, and convulsive seizures, are a frequent component of severe YF, but pathological examination of brain, showing small perivascular hemorrhages and cerebral edema, without significant inflammation or neuronal changes, has not indicated viral replication and encephalitis (Stevenson, 1939). A wide variety of neurological syndromes, including encephalitis during acute dengue or DHF, and postinfectious complications (encephalitis, polyneuritis, Reye's syndrome), have been associated with dengue (Gubler et al., 1983), but neither incontrovertible evidence for an etiological association nor documentation of brain infection (as opposed to secondary effects of hemorrhage and edema) has been obtained.

It thus appears that in primate hosts, dengue and YF viruses rarely if ever cross the blood-brain barrier and establish CNS infection, despite the development of exceedingly high levels of viremia and extraneural infection and (in the case of YF) the encephalitogenic potential of some unadapted virus strains. The susceptibility of cells at the gateway of the brain (capillary endothelial cells and olfactory neurons) to dengue and YF viruses has not been clearly determined in primates, although neurotropic strains of YF virus are pathogenic following intranasal inoculation (Findlay and Clarke, 1935). However, a more likely explanation is provided by the genetic heterogeneity of parental virus populations and the selective replication advantage of viscerotropic virions. Studies in which mixtures of neurotropic and viscerotropic YF virus strains were inoculated by the intraperitoneal route into mice, hedgehogs, and monkeys showed that the viscerotropic virus subpopulation replicated more rapidly than the neurotopic strain (Theiler, 1951). 


\section{Pathogenesis of Dengue Hemorrhagic Fever/Dengue Shock Syndrome}

The pathogenesis of DHF/DSS has been the subject of many comprehensive reviews (Halstead, 1980, 1982a,b; Bhamarapravati, 1981; Pang, 1983), and a brief synopsis is thus appropriate here. DHF/DSS occurs almost exclusively in persons who experience a secondary infection with a heterologous dengue serotype; the seroepidemiological evidence for this is reviewed by Halstead (1980) and is strongly supported by recent studies in Thailand (Sangkawibha et al., 1984). The overall risk of acquiring DHF/ DSS in cases of secondary infection is $2-6 \%$, more than 100 times higher than in cases of primary infection. Young age, female sex, good nutritional status, an interval of less than 5 years between infections, and sequence of infection (e.g., dengue 1 followed by dengue 2 in Thailand), and strain of virus are identified risk factors (Halstead 1980, 1982a). That genetic factors may be involved was suggested by the significantly higher incidence of DHF in whites than in blacks in Cuba in 1981 (Guzman et al., 1985). Human leukocyte antigen (HLA)-associated factors in DHF have not been defined.

The basis for the DHF/DSS syndrome is an abnormal immunological response involving virus-antibody complexes, leukocytes, and complement. Central to the pathogenesis of the syndrome is the concept of IgG antibody-dependent enhancement (ADE) of dengue viral replication in Fc-receptor-bearing monocytes (Halstead et al., 1973a, 1976; Halstead and O'Rourke, 1977; Halstead, 1980). Preformed nonneutralizing heterotypic IgG antibodies complexed with virus promote both attachment to and infection of monocytes (Gollins and Porterfield, 1984), leading to progressive amplification of replication in these target cells in the host. The mechanisms involved, derived largely from in vitro studies employing peripheral-blood leukocytes and M\$like cell lines, are reviewed in Chapter 11. A second type of enhancement, dependent on the CR3 complement receptor, has been described (Cardosa et al., 1983). Evidence for an in vivo role for $\mathrm{ADE}$ comes from experimental sequential infections of monkeys (Halstead et al., 1973b; Marchette et al., 1973) and challenge of monkeys after passive administration of antibodies (Halstead, 1979), in which viremia and tissue virus titers were higher than in nonimmune controls. Peripheral-blood leukocytes from immune humans and monkeys have also been shown to replicate dengue virus to higher titer than leukocytes from nonimmunes (Halstead et al., 1973a). These observations have culminated in the hypothesis that ADE plays a role in DHF/DSS in persons with past heterotypic immunity or in young infants with either passively acquired heterotypic antibody or homotypic antibody that has waned in titer below the end point of neutralization.

The reasons for expression of severe disease in a small subset $(2-6 \%)$ of persons with secondary infections are problematic. Several observa- 
tions, including the finding of enhanced disease in monkeys with lymphoproliferative disorders and enhanced viremias after pertussis immunization (Halstead, 1980), as well as enhanced immune phagocytosis and replication in macrophages following activation with peptidoglycans and bacterial cell wall products (Hotta et al., 1983), indicate that a variety of host-related factors could influence pathogenesis by increasing the number of permissive cells.

DHF/DSS usually occurs in individuals who have previously sustained only one heterotypic dengue infection. Both the interval between prior infection and the sequence of infecting serotypes are important determinants of disease expression (Halstead, 1980). Anamnestic antibody responses early in the course of secondary infection are typically broadly cross-reactive, but examination of early sera for neutralizing antibody titers may reveal the original antigenic sin phenomenon (Halstead et al., 1983), thereby revealing the serotype responsible for primary infection. Original antigenic sin appears to be a general phenomenon for closely related flaviviruses (Inouye et al., 1984). Aside from its practical usefulness in unraveling infection sequences in DHF/DSS, the phenomenon may exaggerate immunological enhancement.

In patients with DHF/DSS, the clinical syndrome, including signs of increased vascular permeability, appear coincident with activation of complement, fibrinogen consumption, and evidence for viral clearance. Halstead $(1980,1982$ a) has proposed that viral clearance mechanisms involving activation of infected monocytes/macrophages by cytotoxic $\mathrm{T}$ cells results in the release of complement-activating enzymes, thromboplastin, and vascular permeability factors. This cascade of events, illustrated in Fig. 10, amplifies itself and mediates pathophysiological events including plasma leakage, hypotension, and abnormal coagulation.

Evidence that CMI responses are involved in viral clearance has been recently reviewed (Pang, 1983) and may be summarized as follows: (1) Circulating killer $T$ cells have been demonstrated in monkeys 5-7 days after dengue infection (Halstead, 1980); (2) human peripheral-blood mononuclear cells participate in cell-mediated cytotoxicity and ADCC reactions (Kurane et al., 1984); (3) transformed lymphocytes are found in large numbers in buffy coat cells from DHF/DSS patients, and blast transformation in response to dengue antigen occurs in peripheral-blood leukocytes from sensitized monkeys (Bhamarapravati, 1981); (4) there is pathological evidence for perivascular inflammatory responses in skin and other tissues resembling a DTH reaction (Bhamarapravati et al., 1967; Bhamarapravati, 1981); (5) the striking lymphocytolysis involving T-celldependent areas of nodes and spleen in autopsy material may reflect an active CMI response and production of cytotoxic factors; and (6) in vivo DTH responses demonstrated in experimental dengue infection of mice (Pang et al., 1982) are mediated by two types of T cells (Ly $+-1.1^{+}$and Ly $+-2.1^{+}$) requiring H-2 histocompatibility (Pang et al., 1984).

The identity of the vascular permeabiity factor presumably released 


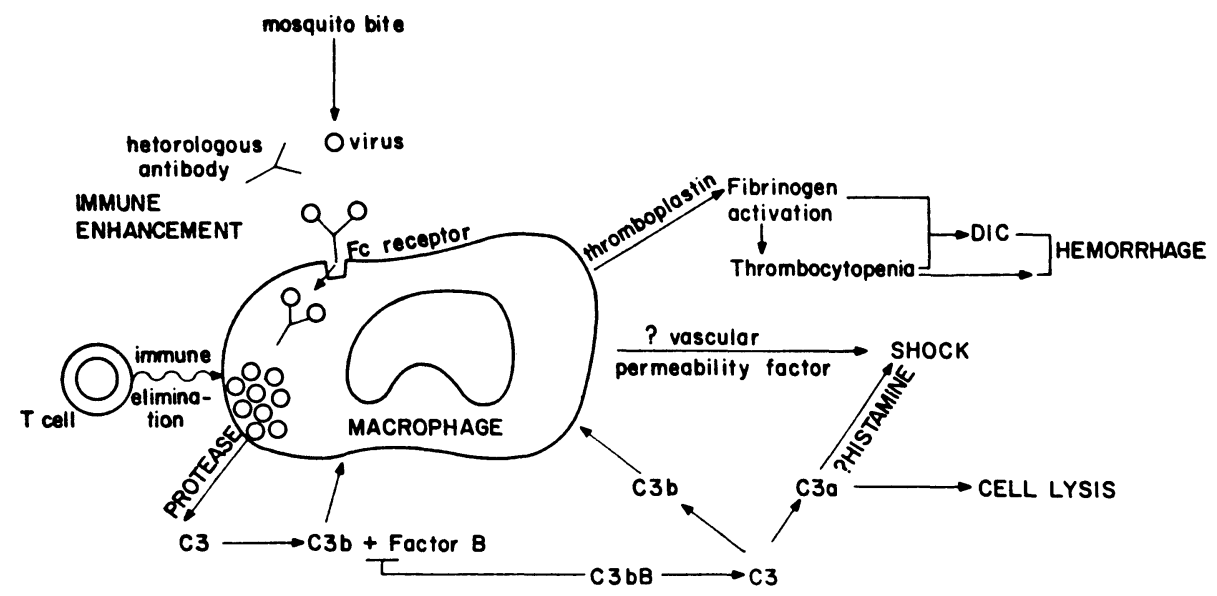

FIGURE 10. Schematic representation of the immune enhancement phenomenon and amplification and effector mechanisms in the pathogenesis of DHF/DSS. Heterologous dengue antibody mediates infection of macrophages. Infected macrophages express dengue viral antigens on plasma membrane and are activated by sensitized $\mathrm{T}$ cells. During the course of immune elimination, infected macrophages release proteases and thromboplastin and initiate activation cascades involving the complement and coagulation systems. Release of a vascular permeability factor may play a role in the development of shock. From Halstead (1982a).

by activated dengue-infected macrophages remains unknown; Pang (1983) proposed that it may be a leukotriene. The kinin system does not appear to be involved (Edelman et al., 1975b). Russell and Brandt (1973) emphasized the role of histamine released from basophils/mast cells in response to complement activation and generation of C3A anaphylatoxin. In support of this concept, Bhamarapravati et al. (1967) noted that some cells in perivascular infiltrates of skin from fatal cases resembled degranulated mast cells, and Tuchinda et al. (1977) have reported increased urinary excretion of histamine by DHF patients. Increased levels of IgE have been found in sera from DHF/DSS patients compared to controls (Pavri et al., 1979), leading Pavri and Prasad (1980) to speculate that IgEmediated histamine release plays a role in the pathogenesis of shock and that underlying parasitic disease may be responsible for elevated IgE. Against the role of histamine-mediated type I hypersensitivity in this disease are observations that DHF/DSS patients do not respond clinically to corticosteroids or antihistamines, nor do they manifest cutaneous signs such as urticaria (Halstead, 1982a).

Hemodynamic and metabolic disturbances associated with increased vascular permeability and shock have been investigated. Patients with DHF/DSS have increased peripheral vascular resistance and diminished cardiac output, presumably due to decreased venous return (Pongpanich and Kumponpant, 1973; Futrakul et al., 1977). In light of other evidence, however, direct viral injury and myocardial dysfunction would appear to 
deserve further study. Metabolic alterations including hyperkalemia, metabolic acidosis, and hypoxemia (Cohen and Halstead, 1966) are probable terminal events in patients with shock (see also Section V.D).

The etiology of the hemorrhagic diathesis in DHF (reviewed by Halstead, 1982b) includes vascular injury, thrombocytopenia, and coagulopathy. Increased capillary fragility (positive tourniquet test) and petechial hemorrhages may be mediated by vasocative mediators, since light- and electron-microscopic studies have not implicated direct viral injury or replication (Sahaphong et al., 1980). Thrombocytopenia may be due to decreased platelet production, but megakaryocytic arrest observed in bone marrow does not appear to coincide temporally with the fall in platelet count (Nelson et al., 1964). Increased turnover of platelets and sequestration in the liver were demonstrated in kinetic studies by $\mathrm{Mi}$ trakul et al. (1977) and increased platelet adhesiveness by Doury et al. (1976). Funahara et al. (1982) have presented evidence for direct attachment of dengue viruses to platelets with subsequent immune elimination, thus explaining the increased severity of thromobocytopenia in cases of secondary infection. Conflicting reports have appeared for an autoimmune basis for thrombocytopenia due to antiplatelet antibodies (Basanta Otero et al., 1983). Defects in platelet function have also been described (Mitrakul et al., 1977; Almagro Vasquez et al., 1983).

A degree of consumption coagulopathy has been demonstrated in a number of clinical studies (World Health Organization, 1973; Srichaikul et al., 1977; Doury et al., 1980); generally, this has been mild, and the coagulation defect has not correlated with severity of illness. In unusual cases involving older patients with severe gastrointestinal hemorrhage, however, disseminated intravascular coagulation may be an important event. Release of thromboplastin by activated dengue-infected macrophages has been suggested as a mechanism for the coagulopathy in DHF/ DSS (Halstead 1982a,b).

Autoantibodies against smooth muscle or mitochrondria have been reported in association with both DHF (Boonpucknavig and Udomsangpetch, 1983) and YF (J. A. Smith et al., 1973). No clinical significance has been attached to these findings, and a number of possible mechanisms may be involved. A recent report showing a monoclonal antibody crossreaction between flaviviral-specified and host-cell proteins (Gould et al., 1983 ) is of interest in this regard.

\section{Yellow Fever: Pathophysiological Correlations}

The availability of suitable nonhuman primate models of YF /which do not exist for DHF/DSS) provides the opportunity to define pathogenesis of this disease, but has not been exhaustively utilized. The evidence suggests similiarity between certain aspects of YF and dengue pathogenesis, although two elements stand apart: (1) lack of evidence for a pathological 
role for antibody-mediated enhancement and (2) the greater hepatotropism and more severe hepatocellular injury in YF.

YF virus has been shown to replicate in monocytes, phytohemagglutinin (PHA)-stimulated lymphocytes, and M $\phi$ like cell lines (Wheelock and Edelman, 1969; Yamamoto and Hotta, 1981; J. J. Schlesinger and Brandriss, 1981; Liprandi and Walder, 1983), as well as in lymph nodes in vivo (Theiler, 1951). Kupffer cells are permissive to viral growth and are important sites of early replication and spread to surrounding liver parenchymal cells. Although YF occurs in geographic areas that are hyperendemic for a number of related flaviviruses, cross-protection rather than immunological enhancement occurs (Monath et al., 1980a). Experimental studies in monkeys support this conclusion (Henderson et al., 1970; Theiler and Anderson, 1975) and show that cross-protection (and absence of enhancement by heterologous viruses) occurs in the absence of YF neutralizing antibodies.

In experimental YF, as in human DHF/DSS, there is marked cytolysis of thymus and T-cell-dependent areas of lymph nodes, spleen, and Payer's patches, but these changes are less marked in human YF. The degree of liver-cell injury, reflected by hyperbilirubinemia and elevation of serum transminases, correlates temporally and quantitatively with disease severity (Oudart and Rey, 1970; Monath et al., 1981). Kupffer cell and hepatocellular necrosis may be central events leading to a number of secondary physiological disturbances, due to impaired biosynthetic and detoxification mechanisms.

Multiple coagulation defects occur in experimental and human YF, including thrombocytopenia and reduction in clotting factors. Although consumption coagulopathy has been documented in monkeys (Dennis et al., 1969) and in humans (Santos et al., 1973), decreased synthesis of vitamin-K-dependent clotting factors by the diseased liver is probably the more important mechanism.

The basis for the renal injury in YF is not entirely clear, but evidence from the monkey model suggests that it may be secondary and physiological in nature (Monath et al., 1981). Studies during the $24 \mathrm{hr}$ before death indicate that renal failure is due to a functional decrease in glomerular filtration rate and renal plasma flow, possibly reflecting increased renovascular resistance, and that renal tubular necrosis occurs as a terminal event associated with shock.

As in DHF/DSS, profound hemodynamic and metabolic alterations occur in severe YF and are probable terminal events. Experimentally infected monkeys become progressively hypotensive, hypoxic, and hyperkalemic during the final hours before death (Monath et al., 1981). Significant changes in cell metabolism reflected in the distribution of tissue water, electrolytes, and trace metals in vital organs (cardiac muscle, medulla oblongata) have been observed (C. T. Liu and Griffin, 1982) and may contribute to cardiorespiratory failure. In contrast to DHF/DSS, in which hemoconcentration, leakage of plasma proteins into the extravascular 
space, and hypovolemia occur, YF-infected monkeys were found to have reduced hematocrits and expanded blood and plasma volumes (C. T. Liu and Griffin, 1982).

There are no studies of circulating mediators of shock in YF. Because of the lesions in reticuloendothelial tissues, Monath et al. (1981) speculated that impaired detoxification of bacterial endotoxin may be involved. In an alphavirus (Venezuelan encephalitis) infection of hamsters, lymphoid necrosis and depletion of reticuloendothelial function have been shown to cause bacterial endotoxemia and death (Gorelkin and Jahrling, 1975). Endotoxin has varied effects on many systems, including mediation of release of effector substances (procoagulants, prostaglandins, and proteolytic enzymes) from M $\phi$ (Nolan, 1981). This potential mechanism for shock in YF and other hemorrhagic fevers should be investigated because of the implication for therapy.

The role of immune responses in recovery from YF has not been characterized. Clearance of viremia coincides with the appearance of neutralizing antibodies and approximately with the onset of severe organ dysfunction (period of intoxication); both antibody and virus (and thus immune complexes) have been found in plasma. Virus replication continues in tissues after disappearance of viremia, but partial or complete clearance from tissues may be evident by the time of death. Both antibody- and cell-mediated immune responses may be involved in viral clearance. Activated T cells have been described in humans given 17D vaccine (Ehrnst et al., 1978), including cells that exhibit cytotoxicity for NKsensitive target-cell lines (Fagraeus et al., 1982). PHA-stimulated peripheral-blood leukocytes taken between 7 and 11 days after YF vaccination are refractory to virus infection (Wheelock et al., 1970). Unlike DHF/ DSS, inflammatory-cell infiltration is not a significant component of the histopathological picture in YF, and direct viral injury rather than immunopathology would appear to explain the pathogenesis of this acute infection. It is possible, however, that deposition of virus-antibody complexes in renal glomeruli could be responsible for morphological changes (Barbareschi, 1957) and albuminuria. Moreover, the contribution of immune responses to the lymphoid necrosis in YF remains uncertain (see below).

\section{E. Immune Modulation, Suppression, and Lymphocytolysis}

A large body of information has resulted from studies showing immune suppression to homologous and heterologous antigens in mice infected with dengue virus (M. Nagarkatti and P. S. Nagarkatti, 1979; M. Nagarkatti et al., 1980; Chaturvedi et al., 1978; Tandon et al., 1979a,b). Two types of immune suppression have been shown, one dengue-virusspecific and a second nonspecific. A T suppressor $\left(\mathrm{TS}_{1}\right)$-cell response occurs in spleens of dengue-primed mice. $\mathrm{TS}_{1}$ lymphocytes produce a sol- 
uble antigen-specific suppressor factor (Chaturvedi and Shukla, 1981) that is presented by direct contact of M $\phi$ like cells to a second subset of $\mathrm{T}$ suppressor cells $\left(\mathrm{TS}_{2}\right)_{\text {; }}$ these cells in turn release prostaglandin, which mediates suppression of dengue-virus-specific IgM antibody PFC in vitro and in vivo (Chaturvedi and Shukla, 1981; Chaturvedi et al., 1981a, 1982a; Shukla and Chaturvedi, 1982, 1983). A third generation of T cells is apparently required to mediate suppression in this system (Shukla and Chaturvedi, 1984).

In contrast, nonspecific immunosuppression is mediated by release of a lymphokine cytotoxic factor (CF) from a different $\mathrm{T}$-cell Ly phenotype (Shukla et al., 1982). CF kills T lymphoctes and M $\phi$ in spleen, lymph nodes, and thymus (Chaturvedi et al., 1980b,c; 1981a,c) and suppresses the immune response to sheep erythrocytes (Chaturvedi et al., 1981b). CF does not kill circulating leukocytes of mice or humans, but adversely affects various functions including phagocytosis by $\mathrm{M} \phi$ and E-rosette formation (Chaturvedi et al., 1982b; Gulati et al., 1982). CF, produced by splenic $\mathrm{T}$ lymphocytes in mice, peaks between 9 and 11 days after inoculation of dengue virus. Contact with $\mathrm{CF}$ induces macrophages to produce an effector cytotoxic factor (CF2), thus providing an amplification step (Gulati et al., 1983a). CF has been partially characterized and found to be heat-labile, trypsin-sensitive, and dialyzable (Chaturvedi et al., 1983a) and has been shown to act on target cells through damage to plasma membranes (Gulati et al., 1983b). In other investigations with mice, dengue virus infection reduced macrophage Fc-mediated attachment and ingestion of opsonized sheep erythrocytes (Chaturvedi et al., 1983b).

In similar studies by Wong et al. (1984), infection of mice with dengue virus resulted in transient immunosuppression of the DTH response to sheep erythrocytes, beginning on day 3 after priming. In contrast to the studies described above, there was no evidence for a soluble $C F$, since suppression was transferable by spleen cells, but not by serum. The cells responsible for suppression had both Ly-1 + and Ly-2 + markers. P. S. Nagarkatti and M. Nagarkatti (1983) have also demonstrated enhanced $\mathrm{T}$-suppressor-cell activity in dengue-virus-infected mice, regulating both $\mathrm{T}$ - and $\mathrm{B}$-cell responses and adoptively transferable to normal mice.

Little is known about the relevance of these observations from experiments with mice to human dengue, in which heightened immune responsiveness rather than immunosuppression appears to occur. Nevertheless, regulation of immune responses in human dengue undoubtedly incorporates T-suppressor-cell activity, and disturbances of regulation could be involved in pathological reactions. A preliminary study of human DHF cases in Cuba (Santos Lagresa et al., 1983) showed reduced T-lymphocyte responsiveness to mitogens and reversal by indomethacin, an inhibitor of prostaglandins [the presumed mediator of dengue-specific T-suppressor activity (Chaturvedi et al., 1981a)]. Another form of autoregulation of the immune response may be provided by autocytotoxic 
antilymphocyte antibodies found in human DHF cases (Boonpucknavig and Udomsangpetch, 1983; Gilbreath et al., 1983).

Little information of a similar nature is available for YF viral infection in mice or primates. Vaccination with YF 17D virus did not suppress tuberculin skin test reactivity in one study (Marvin et al., 1968).

Several possible mechanisms may be put forward to explain the lymphocytolysis and reduction in circulating $T$ cells observed in dengue and YF, including: (1) virus-induced release of cytotoxic factors by sensitized $\mathrm{T}$ cells (Chaturvedi et al., 1980b, 1981c), (2) complement-mediated cytolysis by antilymphocyte antibodies (Gilbreath et al., 1983), (3) local production of lymphotoxins (e.g., C3a) by activated macrophages (Halstead, 1982b), and (4) cytolysis mediated by high levels of endogenous or iatrogenically administered corticosteroids.

\section{F. Persistent and Congenital Infections}

Persistent infections with dengue and YF viruses are readily established in a number of cell cultures, but there is only meager evidence for their occurrence in vivo. Prolonged synthesis of IgM antibodies has been reported following YF 17D vaccination of humans (Monath, 1971), suggesting that the remarkable longevity of immunity to the live vaccine may reflect repeated or continuous antigen stimulation. Persistence of 17D virus in brains of intracerebrally inoculated monkeys for up to 159 days, without change in mouse virulence markers, has been reported (Penna and Bittencourt, 1943); this may reflect the importance of neural tissue in flaviviral persistence and is not an element of natural YF infections.

Congenital infections of lambs and calves with WSL virus have been described in an earlier section. There is no clinical or experimental evidence for congenital infection with dengue (Mirovsky et al., 1962) or YF viruses.

\section{G. Genetic Host Resistance}

Coevolution of YF virus with its nonhuman primate hosts in Africa has apparently led to the development of host resistance and a balanced host-virus relationship. Although most species develop high titers of viremia, African primates are not susceptible to clinical illness or death. In contrast, many species of neotropical monkeys succumb to lethal YF infection, consistent with the probable recent introduction of YF virus from Africa during the 16th century (Warren, 1951).

Associations between HLA genes and susceptibility to YF or dengue have not been investigated. However, an analysis of gene frequencies among descendants of Dutch settlers in Surinam, who had survived out- 
breaks of YF, showed variations that were unlikely to be due to drift (De Vries et al., 1979). The authors suggested that these variations may be due to selection of resistance genes.

Another interesting observation indicates that genetic factors, while they do not affect host resistance/susceptibility per se, may play a role in viral transmission. Aedes aegypti, the urban vector of dengue and YF viruses, preferentially takes blood meals from humans with blood group O rather than group A or B (Wood, 1976).

As mentioned previously, there was a significant excess of DHF cases among whites compared to blacks during the Cuban epidemic in 1981; this was not explained by racial differences in immunological background.

\section{REFERENCES}

Albagai, C., and Chaimoff, R., 1959, A case of West Nile myocarditis, Harefuah 57:274275.

Albrecht, P., 1960, Pathogenesis of experimental infection with tick-borne encephalitis virus, in: Biology of Viruses of the Tick-Borne Encephalitis Complex (H. Libikova, ed.), pp. 247-257, Academic Press, New York.

Albrecht, P., 1968, Pathogenesis of neurotropic arbovirus infections, Curr. Top. Microbiol. Immunol. 43:44-91.

Almagro Vasquez, D., Gonzalez Cabrera, I., Cruz Gomez, Y., and Castaneda Morales, M., 1983, Platelet function in dengue hemorrhagic fever, Acta Haematol. 70:276-277.

Andersen, A. A., and Hanson, R. P., 1970, Experimental transplacental transmission of St. Louis encephalitis virus in mice, Infect. Immun. 2:230-325.

Andersen, A. A., and Hanson, R. P., 1974, Influence of sex and age on natural resistance to St. Louis encephalitis virus infection in mice, Infect. Immun. 9:1123-1125.

Andersen, A. A., and Hanson, R. P., 1975, Intrauterine infection of mice with St. Louis encephalitis virus: Immunological, physiological, neurological, and behavioral effects in progeny, Infect. Immun. 12:1173-1183.

Asher, D. M., 1979, Persistent tick-borne encephalitis infection in man and monkeys: Relation to chronic neurologic disease, in: Arctic and Tropical Arboviruses, Proceedings of the 2nd International Symposium on Arctic Arboviruses (E. Kurstak, ed.), pp. 179195, Academic Press, New York.

Aung-Khin, M., Khin, Ma-Ma, Thant-Zin, 1975, Changes in the tissues of the immune system in dengue hemorrhagic fever, J. Trop. Med. Hyg. 78:256-261.

Badman, R. T., Campbell, J., and Alfred, J., 1984, Arbovirus infections in horses-Victoria, 1984, Communicable Disease Intell No. 84/17, Australia.

Barbareschi, G., 1957, Glomenulosi tossica in febbre gialla, Rev. Biol. Trop. 5:201-209.

Barnes, W. J. S., and Rosen, L., 1974, Fatal hemorrhagic disease and shock associated with primary dengue infection on a Pacific Island, Am. J. Trop. Med. Hyg. 23:495-506.

Basanta Otero, P., Gonzalez Villalonga, C., and Orbeal Aldama, L., 1983, Platelet autoantibodies in dengue hemorrhagic fever, Acta Haematol. 70:141-142.

Bearcroft, W. G. C., 1957, The histopathology of the liver of yellow fever infected rhesus monkey, I. Pathol. Bacteriol. 74:295-303.

Bhamarapravati, N., 1981, Pathology and pathogenesis of DHF, in: Dengue Hemorrhagic Fever, 1981 (S. Hotta, ed.), pp. 207-214, International Center for Medical Research Kobe University School of Medicine Kobe, Japan.

Bhamarapravati, N., and Boonpucknavig, V., 1966, Immunofluorescent study of dengue virus in human cases, Bull. W.H.O. 35:50. 
Bhamarapravati, N., Tuchinda, P., and Boonyapaknavik, V., 1967, Pathology of Thailand haemorrhagic fever: A study in 100 autopsy cases, Ann. Trop. Med. Parasitol. 61:500510.

Bhatt, P. N., and Jacoby, R. O., 1976, Genetic resistance to lethal flavivirus encephalitis. II. Effect of immunosuppression, J. Infect. Dis. 134:166-173.

Bierman, H. R., and Nelson, E. R., 1965, Hematodepressive virus diseases of Thailand, Ann. Intern. Med. 62:867-884.

Blackburn, N. K., and Swanepoel, R., 1980, An investigation of flavivirus infections of cattle in Zimbabwe, Rhodesia with particular reference to Wesselsbron virus, J. Hyg. 85:133.

Bond, J. O., 1969, St. Louis encephalitis and dengue fever in the Caribbean area: Evidence of possible cross-protection, Bull. W.H.O. 40:160-163.

Boonpucknavig, S., and Udomsangpetch, R., 1983, Autoantibodies in viral infection, J. Clin. Lab. Immunol. 10:171-172.

Boonpucknavig, V., Bhamarapravati, N., Boonpucknavig, S., Futradul, P., and Tanpaichitr, P., 1976a, Glomerular changes in dengue hemorrhagic fever, Arch. Pathol. Lab. Med. 100:206-212.

Boonpucknavig, S., Bhamarapravati, N., Nimmannitya, S., Phalavadhtana, A., and Siripont, J., 1976b, Immunofluorescent staining of the surfaces of lymphocytes in suspension from patients with dengue hemorrhagic fever, Am. J. Pathol. 85:37-47.

Boonpucknavig, S., Lohachitranond, C., and Nimmannitya, S., 1979a, The pattern and nature of the lymphocyte population response in dengue hemorrhagic fever, Am. I. Trop. Med. Hyg. 28:885-889.

Boonpucknavig, S., Boonpucknavig, V., Bhamarapravati, N., and Nimmaranitya, S., 1979b, Immunofluorescent study of skin rash in patients with dengue hemorrhagic fever, Arch. Pathol. Lab. Med. 103:463-466.

Boonpucknavig, S., Vettiviroj, O., and Boonpucknavig, V., 1981, Infection of young adult mice with dengue virus type 2, Trans. R. Soc. Trop. Med. Hyg. 75:647-653.

Bowen, G. S., Monath, T. P., Kemp, G. E., Kerschner, J. H., and Kirk, L. J., 1980, Geographic variation among St. Louis encephalitis virus strains in the viremic responses of avian hosts, Am. J. Trop. Med. Hyg. 29:1411-1419.

Bradish, C. J., Fitzgeorge, R., and Titmuss, D., 1980, The responses of normal and athymic mice to infections by togaviruses: Strain differentiation in active and adoptive immunization, J. Gen. Virol. 46:255-265.

Brandriss, M. W., and Schlesinger, J. J., 1984, Passive protection of mice to intracerebral challenge with $17 \mathrm{D}$ yellow fever viruses by monoclonal antibodies to $17 \mathrm{D}$ yellow fever and to dengue 2, Abstr. XI Int. Cong. Trop. Med. Malaria, Calgary, Alb., p. 13.

Brinker, K. R., and Monath, T. P., 1980, The acute disease, in: St. Louis Encephalitis (T. P. Monath, ed.), pp. 503-534, American Public Health Association, Washington, D.C.

Burke, D. S., Schmaljohn, C. S., and Dalrymple, J. M., 1985a, Strains of Japanese encephalitis virus isolated from human brains have a highly conserved genotype compared to strains isolated from other natural hosts, Abstr. Ann. Meet. Am. Soc. Virol., Univ. New Mex., Albuquerque.

Burke, D. S., Lorsomondee, W., Leake, C., Hoke, C. H., Nisalak, A., Chongswasdi, V., and Laorakpongse, T., 1985b, Fatal outcome in acute Japanese encephalitis, Am. J. Trop. Med. Hyg. 34:1203-1210.

Burke, D. S., Nisalak, A., Ussery, M., Laorakpongse, T., and Chantaribul, S., 1985c, Kinetics of Japanese encephalitis virus immunoglobulin $\mathrm{M}$ and $\mathrm{G}$ antibodies in human serum and cerebrospinal fluid, $J$. Infect. Dis. (in press).

Buxton, D., and Reid, H. W., 1975, Experimental infection of red grouse with louping ill virus (flavivirus group). II. Neuropathology, J. Comp. Pathol. 85:231-235.

Camain, R., and Lambert, D., 1966, Histopathologie des foies amarils preleves postmortem et par ponction-biopsie hepatique au cours de l'epidemie de Diourbel (Senegal), Novembre-Decembre, 1965, Bull. Soc. Med. Afr. Noire Lang. Fr. 11:522-540. 
Camenga, D. L., and Nathanson, N., 1975, An immunopathologic component in experimental togavirus encephalitis, $I$. Neuropathol. Exp. Neurol. 34:492-500.

Camenga, D. L., Nathanson, N., and Cole, G. A., 1974, The relative influence of cellular and humoral factors in the modification of cyclophosphamide-potentiated West Nile virus encephalitis, J. Infect. Dis. 130;634-641.

Cantanzaro, P. J., Brandt, W. E., Hogrefe, W. R., and Russell, P. K., 1974, Detection of dengue cell surface antigens by peroxidase labelled antibodies and immune cytolysis, Infect. Immun. 10:381-388.

Cardosa, M. J., Porterfield, J. S., and Gordon, S., 1983, Complement receptor mediates enhanced flavivirus replication in macrophage, J. Exp. Med. 158:258-263.

Cardosa, M. J., Gordon, S., Hirsch, S., Springer, T. A., and Porterfield, J. S., 1986, Interaction of West Nile virus with primary murine macrophages: Role of cell activation and receptors for antibody and complement, $J$. Virol. (in press).

Casals, J., Henderson, B. E., Hoogstraal, H., Johnson, K., and Shelokov, A., 1970, A review of Soviet hemorrhagic fevers, 1969, J. Infect. Dis. 122:437-453.

Chamberlain, R. W., 1958, Vector relationships of the arthropod-borne encephalitides in North America, Ann. N. Y. Acad. Sci. 70:312-319.

Chaturvedi, U. C., and Shukla, M. I., 1981, Characterization of the suppressor factor produced in the spleen of dengue virus infected mice, Ann. Immunol. (Paris) 132C:245255.

Chaturvedi, U. C., Tandon, P., Mathur, A., and Kumar, A., 1978, Host defense mechanisms against dengue virus infection in mice, J. Gen. Virol. 39:293-302.

Chaturvedi, U. C., Mathur, A., Tandon, P., Natu, S. M., Rajvanshi, S., and Tandon, H. O., 1979 , Variable effect on peripheral blood leukocytes during JE virus infection of man, Clin. Exp. Immunol. 38:492-498.

Chaturvedi, U. C., Mathur, A., Chandra, A., Das, S. K., Tandon, H. O., and Singh, U. K., 1980a, Transplacental infection with Japanese encephalitis virus, J. Infect. Dis. 141:712-715.

Chaturvedi, U. C., Bhargava, A., and Mathur, A., 1980b, Production of cytotoxic factor in the spleen of dengue virus-infected mice, Immunology 40:653-658.

Chaturvedi, U. C., Dalakoti, H., and Mathur, A., 1980c, Characterization of the cytotoxic factor produced in the spleen of dengue virus-infected mice, Immunology 41:387-392.

Chaturvedi, U. C., Shukla, M. I., and Mathur, A., 1981a, Thymus dependent lymphocytes of the dengue virus infected mouse spleen mediate suppression through prostaglandin, Immunology 42:1-6.

Chaturvedi, U. C., Shukla, M. I., Mathur, K. R., and Mathur, A., 1981b, Dengue virus-induced cytotoxic factor suppresses immune response of mice to sheep RBC, Immunology 43:311-316.

Chaturvedi, U. C., Mathur, K. R., Gulati, L., and Mathur, A., 1981c, Target lymphoid cells for the cytotoxic factor produced in the spleen of dengue virus-infected mice, Immunol. Lett. 3:13-16.

Chaturvedi, U. C., Shukla, M. I., and Mathur, A., 1982a, Role of macrophages in transmission of dengue virus-induced suppressor signal to a subpopulation of T lymphocytes, Ann. Immunol. (Paris) 133C:83-92.

Chaturvedi, U. C., Gulati, L., and Mathur, A., 1982b, Inhibition of E-rosette formation and phagocytosis by human blood leukocytes after treatment with dengue virus-induced cytotoxic factor, Immunology 45:679-685.

Chaturvedi, U. C., Gulati, L., and Mathur, A., 1983a, Further studies on the production of dengue virus-induced macrophage cytotoxin, Ind. J. Exp. Biol. 21:235-279.

Chaturvedi, U. C., Nagar, R., and Mathur, A., 1983b, Effect of dengue virus infection on Fc receptor functions of mouse macrophages, J. Gen. Virol. 64:2399-2407.

Chunikhin, S. P., and Kurenkov, V. B., 1979, Viraemia in Clethrionomys glareolus-a new ecological marker of tick-borne encephalitis virus, Acta Virol. 23:257-260.

Clarke, D. H., 1960, Antigenic analysis of certain group B arthropod-borne viruses by antibody absorption, J. Exp. Med. 111:21-32. 
Clarke, D. H., 1969, Further studies on antigenic relationships among the viruses of the group B tick-borne complex, Bull. W.H.O. 31:45-56.

Coetzer, J. A. W., and Barnard, J. H., 1977, Hydrops amnii in sheep with hydranencephaly and arthrogryposis with Wesselsbron and Rift Valley fever as aetiological agents, Onderstepoort J. Vet. Res. 44:119-126.

Coetzer, J. A. W., and Theodoridis, A., 1982, Clinical and pathological studies in adult sheep and goats experimentally injected with Wesselsbron disease virus, Onderstepoort J. Vet. Res. 49:19-22.

Coetzer, J. A. W., Theodoridis, A., and Van Heerden, A., 1978, Wesselsbron disease: Pathological, haematological and clinical studies in natural lcases and experimentally infected newborn lambs, Onderstepoort I. Vet. Res. 45:93-106.

Cohen, S. N., and Halstead, S. B., 1966, Shock associated with dengue infection. 1. Clinical and physiologic manifestations of dengue hemorrhagic fever in Thailand, 1964, J.Pediatr. 68:448-456.

Cole, G. A., and Nathanson, N., 1968, Potentiation of experimental arbovirus encephalitis by immunosuppressive doses of cyclophosphamide, Nature (London) 220:399-401.

Cole, G. A., and Wisseman, C. L., Jr., 1969, The effect of hyperthermia on dengue virus infection of mice, Proc. Soc. Exp. Biol. Med. 130:359-363.

Cypress, R. H., Lubiniecki, A. S., and Hammon, W. McD., 1973, Immunosuppression and increased susceptibility to Japanese B encephalitis virus in Trichinella sprialis-infected mice, Proc. Soc. Exp. Biol. Med. 143:469-473.

Darnell, M. B., and Koprowski, H., 1974, Genetically determined resistance to infection with group B arboviruses. II. Increased production of interfering particles in cell culture from resistant mice, I. Infect. Dis. 129:208-256.

David-West, T. S., 1975, Concurrent and consecutive infection and immunization with yellow fever and UGMP-359 virus, Arch. Virol. 48:21-28.

David-West, T. S., and Smith, J. A., 1971, Yellow fever virus infection: A correlation of complement fixing antigen with histopathology, Br. J. Exp. Pathol. 52:114-121.

Del Canto, M. C., and Rabinowitz, S. G., 1982, Experimental models of virus-induced demyelination of the central nervous system, Ann. Neurol. 11:109-127.

Dennis, L. H., Reisberg, B. E., Crosbie, J., Crozier, D., and Conrad, M. E., 1969, The original haemorrhagic fever: Yellow fever, Br. J. Haematol. 17:455-462.

DeVries, R. R. P., Meera Khan, P., Bernini, L. F., van Loghem, E., and van Rood, J. J., 1979, Genetic control of survival in epidemics, I. Immunogenet. 6:271-287.

Doherty, P. C., and Reid, H. W., 1971, Louping ill encephalomyelitis in the sheep. II. Distribution of virus and lesions in nervous tissue, J. Comp. Pathol. 81:531-536.

Doi, R., Oya, A., Shirasaka, A., Yabe, S., and Sasa, M., 1983, Studies on Japanese encephalitis virus infection of reptiles. II. Role of lizards on hibernation of Japanese encephalitis virus, Ipn. J. Exp. Med. 53:125-134.

Doury, J. C., Teyssier, J., Forcain, A., and Doury, F., 1976, Modifications de l'adhésivité plaquettaire au cours de la dengue à forme hémorrhagiques, Bull. Soc. Pathol. Exot. 69:493-495.

Doury, J. C., Teyssier, J., Doury, F., Gentile, B., and Forçain, M., 1980, Dengue à forme hémorrhagique: Mise en evidence d'un syndrome de coagulopathie de consommation, Med. Trop. (Marseille) 40:127-135.

Duffy, C. E., and Murphree, O. D., 1959, Maze performance of mature rats recovered from early postnatal infection with Murray Valley encephalitis, J. Comp. Physiol. Psychol. 52:175-180.

Duffy, O. D., Murphree, O. D., and Morgan, P. N., 1958, Learning deficit in mature rats recovered from early post-natal infection with West Nile virus, Proc. Soc. Exp. Biol. Med. 98:242-244.

Eckels, K. H., Brandt, W. E., Harrison, V. R., McConn, J. M., and Russell, P. K., 1976, Isolation of a temperature-sensitive dengue 2 virus under conditions suitable for vaccine development, Infect. Immun. 14:1221-1227.

Edelman, R., Schneider, R. J., and Chieowanich, P., 1975a, The effect of dengue virus in- 
fection on the clinical sequelae of Japanese encephalitis: A one year followup study in Thailand, Southeast Asian J. Trop. Med. Public Health 6:308-315.

Edelman, R., Nimmannitya, S., Colman, R. W., Talamo, R. C., and Top, F. H., Jr., 1975b, Evaluation of the plasma kinin system in dengue hemorrhagic fever, J. Lab. Clin. Med. 86:410-421.

Edelman, R., Schneider, R. J., Vejiajiva, A., Pornpibul, R., and Voodhikul, P., 1976, Persistence of virus specific IgM and clinical recovery after Japanese encephalitis, Am. J. Trop. Med. Hyg. 23:733-738.

Ehrenkrantz, N. J., Zemel, E. S., Bernstein, C., and Slater, K., 1974, Immunoglobulin M in the cerebrospinal fluid of patients with arbovirus encephalitis and other infections of the central nervous system, Neurology 24:976-980.

Ehrnst, A., Lambert, B., and Fagraeus, A., 1978, DNA synthesis in subpopulations of blood mononuclear leucocytes in human subjects after vaccination against yellow fever, Scand. J. Immunol. 8:339-346.

El Dadah, A. H., Nathanson, N., and Sarsitis, R., 1967, Pathogenesis of West Nile encephalitis in mice and rats. I. Influence of age and species on mortality and infections, Am. J. Epidemiol. 86:765-775.

Elton, N. W., Romero, A., and Trejos, A., 1955, Clinical pathology of yellow fever, Am. J. Clin. Pathol. 25:135-146.

Embil, J. A., Camfield, P., Artsob, H., and Chase, D. P., 1983, Powassan virus encephalitis resembling herpes simplex encephalitis, Arch Intern. Med. 143:341-343.

Estrin, W. J., 1976, The serological diagnosis of St. Louis encephalitis in a patient with the syndrome of opsoclonia, body tremulousness and benign encephalitis, Ann. Neurol. 1:596-598.

Fagraeus, A., Ehrnst, A., Klein, E., Patarroyo, M., and Goldstein, G., 1982, Characterization of blood mononuclear cells reacting with $\mathrm{K} 562$ cells after yellow fever vaccination, Cell. Immunol. 67:37-48.

Findlay, G. M., and Clarke, L. P., 1934, Susceptibility of hedgehog to yellow fever: Viscerotropic virus, Trans. R. Soc. Trop. Med. Hyg. 28:193-200.

Findlay, G. M., and Clarke, L. P., 1935, Infection with neurotropic yellow fever virus following instillation into nares and conjunctival sac, J. Pathol. Bacteriol. 40:55-64.

Fitzgeorge, R., and Bradish, C. J., 1980, The in vivo differentiation of strains of yellow fever virus in mice, J. Gen. Virol. 46:1-13.

Fleming, P., 1977, Age-dependent and strain-related differences of virulence of Semliki Forest virus in mice, J. Gen. Virol. 37:93-105.

Fokina, G. I., Malenko, G. V., Levina, L. S., Koreshkova, G. V., Rzhakhova, O. E., Mamonenko, L. L., Pogodina, V. V., and Frolova, M. P., 1982, Persistence of tick-borne encephalitis virus. V. Virus localization after subcutaneous inoculation, Acta Virol. 26:369-375.

Francis, T., Moore, D. L., Edington, G. M., and Smith, J. A., 1972, A clinicopathological study of human yellow fever, Bull. W.H.O. 46:659-667.

Fresh, J. W., Reyes, V., Clarke, E. J., and Uylangco, C. V., 1969, Philippine hemorrhagic fever: A clinical, laboratory and necropsy study, J. Lab. Clin. Med. 73:451-458.

Funahara, Y., Fujita, N., Okuno, Y., Ogawa, K., Hirata, M., Miki, M., and Kitaguchi, H., 1982, Virus-induced thrombocytopenia: In vitro studies on the dengue virus-platelet interaction, Blood Vessel 13:341-344.

Futrakul, P., Mitrakul, C., Chumderpadetsuk, S., and Sitprija, V., 1977, Studies on the pathogenesis of dengue hemorrhagic fever: Hemodynamic alteration and effect of alpha blocking agent, J. Med. Assoc. Thailand 60:610-614.

Gainer, S. H., and Pry, T. W., 1972, Effect of arsenicals on viral infections in mice, Am. J. Vet. Res. 33:2299-2307.

Gajdosova, E., Mayer, V., and Oravec, C., 1980, Cross-reactive killer T lymphocytes in a flavivirus infection, Acta Virol. 24:291-293.

Gajdosova, E., Oravec, C., and Mayer, V., 1981, Cell mediated immunity in flavivirus infections. I. Induction of cytotoxic $\mathrm{T}$ lymphocytes in mice by an attenuated virus from 
the tick-borne encephalitis complex and its group-reactive character, Acta Virol. 25:1018.

Gardner, J. J., and Reyes, M. G., 1980, Pathology, in: St. Louis Encephalitis (T. P. Monath, ed.), pp. 551-569, American Public Health Association, Washington, D.C.

Gerhard, W., and Koprowski, H., 1977, Persistence of virus-specific memory B cells in mice CNS, Nature (London) 266:360-361.

Gilbreath, M. J., Pavarand, K., MacDermott, R. P., Ussery, M., Burke, D. S., Nimmannitya, S., and Tulyayon, S., 1983, Cold-reactive immunoglobulin M antilymphocyte antibodies directed against B cells in Thai children with dengue hemorrhagic fever, J. Clin. Microbiol. 17:672-676.

Goldman, J., Bochna, A., and Becker, F. O., 1977, St. Louis encephalitis and subacute thyroiditis, Ann. Intern. Med. 87:250.

Gollins, S. W., and Porterfield, J. S., 1984, Flavivirus infection enhancement in macrophages: Radioactive and biological studies on the effect of antibody on viral fate, J. Gen. Virol. 65:1261-1272.

Gorelkin, L., and Jahrling, P. B., 1975, Virus-initiated septic shock: Acute death of Venezuelan encephalitis virus-infected hamsters, Lab. Invest. 32:78-85.

Gould, E. A., Chanas, A. C., Buckley, A., and Clegg, C. S., 1983, Monoclonal immunoglobulin $M$ antibody to Japanese encephalitis virus that can react with a nuclear antigen in mammalian cells, Infect. Immun. 41:774-779.

Gresikova, M., 1957, Elimination of tick-borne encephalitis virus by goat's milk, Vet. Cas. 6:177-182 (in Slovak).

Gresikova, M., and Nosek, J., 1983, Marker stability of the Skalica strain (from the tickborne encephalitis complex) propagated in Ixodes ricinus ticks, Acta Virol. 27:180182.

Gresikova, M., and Sekeyova, M., 1980, Characteristics of some tick-borne encephalitis virus strains isolated in Slovakia, Acta Virol. 24:72-75.

Griffin, D. E., 1981, Immunoglobulins in the cerebrospinal fluid: Changes during acute viral encephalitis in mice, J. Immunol. 126:27-31.

Griffin, D. E., Mokhtarian, F., Park, M. M., and Hirsch, R. L., 1983, Immune responses to acute alphavirus infection of the central nervous system; Sindbis virus encephalitis in mice, prog. Brain Res. 59:11-21.

Grimstad, P. R., Ross, Q. E., and Craig, G. B., Jr., 1980, Aedes triseriatus (Diptera: Culicidae) and La Crosse virus. II. Modification of mosquito feeding behavior by virus infection, J. Med. Entomol. 17:1-7.

Grossberg, S. E., and Scherer, W. F., 1966, The effect of host age, virus dose and route of inoculation on inapparent infection in mice with Japanese encephalitis virus, Proc. Soc. Exp. Biol. Med. 123:118-124.

Gubler, D. J., Suharyono, W., Sumarmo, Wulur, H., Jahja, E., and Sulianti Saroso, J., 1979, Virological surveillance for dengue haemorrhagic fever in Indonesia using the mosquito inoculation technique, Bull. W.H.O. 57:931-936.

Gubler, D. J., Kuno, G., and Waterman, S., 1983, Neurologic disorders associated with dengue infection, in: Procedings of the International Conference on Dengue/Dengue Haemorrhagic Fever (T. Pang and R. Pathmanathan, eds.), pp. 290-306. University of Malaya, Kuala Lampur.

Guillon, J. C., Oudar, J., Joubert, L., and Hannoun, C., 1968, Lesions histologiques du systeme nerveux dans l'infection a virus West Nile chez le cheval, Ann. Inst. Past. 114:539550.

Gulati, L., Chaturvedi, U. C., and Mathur, A., 1982, Depressed macrophage functions in dengue virus-infected mice: Role of the cytotoxic factor, Br. J. Exp. Pathol. 63:194-202.

Gulati, L., Chartuvedi, U. C., and Mathur, A., 1983a, Dengue virus-induced cytotoxic factor induces macrophages to produce a cytotoxin, Immunology 49:121-130.

Gulati, L., Chaturvedi, U. C., and Mathur, A., 1983b, Plasma membrane-acting drugs inhibit the effect of dengue virus-induced cytotoxic factor, Ann. Immunol. (Paris) 134C:227235. 
Guzman, M. G., Kouri, G., Morier, L., Soler, M., and Fernandez, A., 1984, A study of fatal hemorrhagic dengue cases in Cuba, 1981, Bull P.A.H.O. 18:213-220.

Guzman, M. G., Kouri, G., Bravo, J., Soler, M., and Vasquez, S., 1985, Dengue hemorrhagic fever in Cuba, 1981, II. Study of patients clinically diagnosed with dengue hemorrhagic fever and dengue shock syndrome, Trans. R. Soc. Trop. Med. Hyg. (in press).

Habu, A., Murakanu, Y., Ogasa, A., and Fujisaki, Y., 1977, Disorder of spermatogenesis and viral discharge into semen in boars infected with Japanese encephalitis, Virus 27:2126.

Halstead, S. B., 1979, In vivo enchancement of dengue virus infection in rhesus monkeys by passively transferred antibody, I. Infect. Dis. 140:527-533.

Halstead, S. B., 1980, Immunopathological parameters of togavirus disease syndromes, in: The Togaviruses: Biology, Structure, Replication (R. W. Schleslinger, ed.), pp. 107-174, Academic Press, New York.

Halstead, S. B., 1982a, Immunopathology in viral disease: Immune enhancement of dengue virus infection, in: Virus Infections: Modern Concepts and Status (L. C. Olson, ed.), pp. 41-85, Marcel Dekker, New York.

Halstead, S. B., 1982b, Dengue: Hematological aspects, Semin. Hematol. 19:116-131.

Halstead, S. B., and O'Rourke, E. J., 1977, Dengue viruses and mononuclear phagocytes. I. Infection enhancement by non-neutralizing antibody, J. Exp. Med. 146:201-217.

Halstead, S. B., Chow, J. S., and Marchette, M. J., 1973a, Immunological enhancement of dengue virus replication, Nature (London) 243:24-25.

Halstead, S. B., Shotwell, H., and Casals, J., 1973b, Studies on the pathogenesis of dengue infection in monkeys. II. Clinical laboratory responses to heterologous infection, $J$. Infect. Dis. 128:15-22.

Halstead, S. B., Marchette, N. J., Chow, J. S., and Lolekha, S., 1976, Dengue virus replication enhancement in peripheral blood leukocytes from immune human beings, Proc. Soc. Exp. Biol. Med. 151:136-139.

Halstead, S. B., O'Rourke, E. J., and Allison, A. C., 1977, Dengue viruses and mononuclear phagocytes. II. Identity of blood and tissue leukocytes supporting in vitro infection, $J$. Exp. Med. 146:218-229.

Halstead, S. B., Rojanasuphot, S., and Sangkawibha, N., 1983, Original antigenic sin in dengue, Am. J. Trop. Med. Hyg. 32:154-156.

Halstead, S. B., Venkateschan, C. N., Gentry, M. K., and Larsen, L. K., 1984, Heterogeneity of infection enhancement of dengue 2 strains by monoclonal antibodies, J. Immunol. 132:1529-1532.

Hambleton, P., Stephenson, J. R., Baskerville, A., and Wiblin, C., 1983, Pathogenesis and immune response of vaccinated and unvaccinated rhesus monkeys to tick-borne encephalitis virus, Infect. Immun. 40:995-1003.

Hammon, W. McD., and Sather, G. E., 1973, Passive immunity for arbovirus infection. I. Artificially induced prophylaxis in man and mouse for Japanese encephalitis, Am. J. Trop. Med. Hyg. 22:524-534.

Harrison, V. R., Eckels, K. H., Sagartz, J. W., and Russell, P. K., 1977, Virulence and immunogenicity of a temperature-sensitive dengue 2 virus in lower primates, Infect. Immun. 18:151-156.

Harrison, A., Murphy, F. A., Gardner, J. J., and Bauer, S. P., 1980, Myocardial and pancreatic necrosis induced by Rocio virus, a new flavivirus, Exp. Mol. Pathol. 32:102-113.

Harrison, A., Murphy, F. A., and Gardner, J. J., 1982, Visceral target organs in systemic St. Louis encephalitis virus infection of hamsters, Exp. Mol. Pathol. 37:292-304.

Hayashi, K., and Arita, T., 1977, Experimental double infection of Japanese encephalitis and herpes simplex virus in mouse brain, Ipn. J. Exp. Med. 47:9-13.

Haymaker, W., and Sabin, A. B., 1947, Topographic distribution of lesions in the central nervous system in Japanese B encephalitis, Arch. Neurol. Psychol. 57:673-692.

Heinz, F. X., and Kunz, C., 1982, Molecular epidemiology of tick-borne encephalitis virus: Peptide mapping of large non-structural proteins of European isolates and comparison with other flaviviruses, J. Gen. Virol. 62:271-285. 
Heinz, F. X., Berger, R., Majdic, O., Knapp, W., and Kunz, C., 1982, Monoclonal antibodies to the structural glycoprotein of tick-borne encephalitis virus, Infect. Immun. 37:869874.

Henderson, B. E., Cheshire, P. P., Kirya, A. B., and Lule, M., 1970, Immunologic studies with yellow fever and selected African group B arboviruses in rhesus and vervet monkeys, Am. J. Trop. Med. Hyg. 19:110-118.

Hirsch, M. S., and Murphy, F. A., 1967, Effects of anti-thymocyte serum on 17D yellow fever infection in adult mice, Nature (London) 216:179-180.

Hofmann, H., Frisch-Niggemeyer, W., Heinz, F., and Kunz, C., 1979, Immunoglobulins to tick-borne encephalitis in the cerebrospinal fluid of man, J. Med. Virol. 4:241-245.

Holland, J. J., 1984, Continuum of change in RNA virus genomes, in: Concepts in Viral Pathogenesis (A. L. Notkins and M. B. A. Oldstone, eds.), pp. 137-143, Springer-Verlag, New York.

Holland, J., Spindler, V., Horodyski, F., Grabau, E., Nichol, S., and VandePol, S., 1982, Rapid evolution of RNA genomes, Science 215:1577-1585.

Hotta, H., Murakami, I., Miyasaki, K., Takeda, Y., Shirane, H., and Hotta, S., 1981a, Inoculation of dengue virus into nude mice, J. Gen. Virol. 52:71-76.

Hotta, H., Murakami, I., Miyasaki, K., Takeda, Y., Shirane, H., and Hotta, S., 1981b, Localization of dengue virus in nude mice, Microbiol. Immunol. 25:89-93.

Hotta, H., Hotta, S., Matsumura, T., Wiharta, A. S., Sujudi, Kotani, S., Takada, H., and Tsuji, M., 1983, Increased production of dengue virus in mouse peritoneal macrophage cultures: A possible mechanism underlying the pathogenesis of severe dengue infection, Proceedings of the International Conference on Dengue and Dengue Hemorrhagic Fever (T. Pang and R. Pathanathan, eds.), pp. 320-324, University of Malaysia, Kuala Lampur.

Huang, C. H., 1957, Studies of virus factors as causes of inapparent infections in Japanese B encephalitis: Virus strains, viraemia, stability to heat and infective dosage, Acta Virol. 1:36-45.

Huang, C. H., 1982, Studies of Japanese encephalitis in China, Adv. Virus Res. 27:71-101.

Huang, C. H., and Wong, C., 1963, Relation of the peripheral multiplication of Japanese B encephalitis virus to the pathogenesis of the infection in mice, Acta Virol. 7:322-330.

Hudson, B. W., Wolff, K., and DeMartini, J. C., 1979, Delayed-type hypersensitivity responses in mice infected with St. Louis encephalitis virus; Kinetics of the response and effects of immunoregulatory agents, Infect. Immunol. 24:71-76.

Ilienko, V. I., and Pokrovskaya, O. A., 1960, Clinical picture in Macaccus rhesus monkeys infected with various strains of tick-borne encephalitis virus, in: Biology of the Viruses of the Tick-Borne Encephalitis Complex (H. Libikova, ed.), pp. 266-269, Academic Press, New York.

Ilienko, V. I., Komandenko, N. I., Platonov, V. G., Prozorova, I. N., and Panov, A. G., 1974, Pathogenetic study on chronic forms of tick-borne encephalitis, Acta Virol. 18:341346.

Inouye, S., Matsuno, S., and Yashito, T., 1984, "Original antigenic sin" phenomenon in experimental flavivirus infections of guinea pigs: Studies by enzyme-linked immunosorbent assay, Microbiol. Immunol. 28:569-574.

Ishak, K. G., Walker, D. H., Coetzer, J. A. W., Gardner, J. J., and Gorelkin, L., 1982, Viral hemorrhagic fevers with hepatic involvement: Pathologic aspects with clinical correlations, Prog. Liver Dis. 7:495-515.

Ishii, K., Matsunaga, Y., and Kono, R., 1968, Immunoglobulins produced in response to Japanese encephalitis virus infections of man, J. Immunol. 101:770-775.

Ishii, K., Matsushita, M., and Hamada, S., 1977, Characteristic residual neuropathological features of Japanese B encephalitis, Acta Neuropathol. 38:181-186.

Jacoby, R. O., Bhatt, P. N., and Schwartz, A., 1980, Protection of mice from lethal flavivirus encephalitis by adoptive transfer of splenic cells from donors infected with live virus, J. Infect. Dis. 141:617-624. 
Jahrling, P. B., 1976, Virulence heterogeneity of a predominantly avirulent western equine encephalitis virus population, J. Gen. Virol. 32:121-127.

Jacoby, R. O., and Bhatt, P. N., 1976, Genetic resistance to lethal flavivirus encephalitis. I. Infection of congenic mice with Banzi virus, J. Infect. Dis. 134:158-169.

Jahrling, P. B., and Gorelkin, L., 1975, Selective clearance of a benign clone of Venezuelan equine encephalitis virus from hamster plasma by hepatic reticuloendothelial cells, $J$. Infect. Dis. 132:667-676.

Jahrling, P. B., and Scherer, W. F., 1973, Growth curves and clearance rates of virulent and benign Venezuelan encephalitis viruses in hamsters, Infect. Immun. 8:456-462.

Johnson, R. T., 1980, Selective vulnerability of neural cells to viral infections, Brain 103:447-472.

Johnson, R. T., 1982, Viral Infections of the Nervous System, Raven Press, New York, 433 pp.

Johnson, R. T., Burke, D. S., Elwell, M., Leake, C. J., Nisalak, A., Hoke, C. H., and Lorsomrudee, W., 1985, Japanese encephalitis: Immunocytochemical studies of viral antigen and inflammatory cells in fatal cases, Ann. Neurol. 18:567-573.

Kaplan, A. M., and Koveleski, J. T., 1978, St. Louis encephalitis with particular involvement of the brain stem, Arch. Neurol. 35:45-46.

Kelkar, S., 1982, Protection against Japanese encephalitis virus in infant mice by concanavalin A., Indian. J. Med. Res. 76:47-52.

Kitamura, T., 1975, Hematogenous cells in experimental Japanese encephalitis, Acta Neuropathol. 32:341-346.

Kitamura, T., Hattori, H., Fujita, S., 1972, EM-autoradiographic studies on the inflammatory cells in experimental Japanese encephalitis, J. Electron Microsc. 21:315-322 (in Japanese).

Klotz, O., and Belt, T. H., 1930, Pathology of the liver in yellow fever, Am. J. Pathol. 6:663687.

Kono, R., and Kim, K. H., 1969, Comparative epidemiological features of Japanese encephalitis in the Republic of Korea, China (Taiwan) and Japan, Bull. W.H.O. 40:263-277.

Kozuch, O., Nosek, J., Ernek, E., Lichard, M., and Albrecht, P., 1963, Persistence of tickborne encephalitis virus in hibernating hedgehogs and dormice, Acta Virol. 7:430-433.

Kozuch, O., Chunikhin, S. P., Gresikova, M., Nosek, J., Kuenkov, V. B., and Lysy, J., 1981, Experimental characteristics of viremia caused by two strains of tick-borne encephalitis virus in small rodents, Acta Virol. 25:219-224.

Kundin, W. D., Liu, C., Hysell, P., and Hamachige, S., 1963, Studies on West Nile virus infection by means of fluorescent antibodies, Arch. Gesamte Virusforsch. 12:514-528.

Kuno, G., 1982, Persistent infection of a nonvector mosquito cell line (TRA-171) with dengue viruses, Intervirology 18:45-55.

Kurane, I., Hebblewhite, D., Brandt, W. E., and Ennis, F. A., 1984, Lysis of dengue virusinfected cells by natural cell-mediated cytotoxicity and antibody-dependent cell-mediated cytotoxicity, J. Virol. 52:223-230.

Lam, K.-W., Burke, D. S., Siemans, M., Cipperly, V., Li, C.-Y., and Lam, L. T., 1982, Characterization of serum acid phosphatase associated with dengue hemorrhagic fever, Clin. Chem. 28:2296-2299.

Lee, H. W., 1968, Multiplication and antibody formation of Japanese encephalitis virus in snakes, II. Proliferation of the virus, Seoul J. Med. 9:147-161.

Lehtinen, I., and Halonen, J.-P., 1984, EEG findings in tick-borne encephalitis, J. Neurol, Neurosurg. Psychiatry 47:500-504.

LeMercier, G., Guerin, M., and Collomto, H., 1966, Etude histopathologique de l'encéphalite consécutive à l'inoculation du vaccin antiamaril de l'Institut Pasteur de Dakar, Bull. Soc. Med. Afr. Noire Lang. Fr. 11:601-609.

LeRoux, J. M. W., 1959, The histopathology of Wesselsbron disease in sheep, Onderstepoort J. Vet. Res. 28:237-243.

Liprandi, F., and Walder, R., 1983, Replication of virulent and attenuated strains of yellow 
fever virus in human monocytes and macrophage-like cell lines (4937), Arch. Virol. 76:51-61.

Liu, C. T., and Griffin, M. J., 1982, Changes in body fluid compartments, tissue water and electrolyte distribution, and lipid concentrations in rhesus macaques with yellow fever, Am J. Vet. Res. 43:2013-2018.

Liu, J.-L., 1972, Protective effect of interferon on mice experimentally infected with Japanese encephalitis virus, Chinese J. Microbiol. 5:1-9.

Lloyd, W., 1931, The myocardium in yellow fever, Am. Heart J. 6:504-516.

Lubiniecki, A. S., Cypress, R. H., and Hammon, W. McD., 1973, Passive immunity for arbovirus infection. I. Artificially acquired protection in mice for Japanese (B) encephalitis virus, Am. J. Trop. Med. Hyg. 22:535-542.

Lubiniecki, A. S., Cypress, R. H., and Lucas, J. P., 1974, Synergistic interaction of two agents in mice: Japanese B encephalitis virus and Trichinella spiralis, Am. J. Trop. Med. Hyg. 23:235-241.

MacDonald, F., 1952, Murray Valley encephalitis infection in the laboratory mouse. I. Influence of age on susceptibility to infection, Aust. J. Exp. Biol. Med. 30:319-326.

Malkova, D., 1960, The role of the lymphatic system in experimental infections with tickborne encephalitis. I. The tick-borne encephalitis virus in the lymph and blood of experimentally infected sheep, Acta Virol. 4:233-240.

Malkova, D., and Kolman, J. M., 1964, Role of the regional lymphocytic system of the immunized mouse in penetration of the tick-borne encephalitis virus into one blood strain, Acta Virol. 8:10-13.

Marburg, K., Goldblum, N., Sterk, V. V., Jasinka-Klingberg, W., and Klingberg, M. A., 1956, The natural history of West Nile fever. I. Clinical observations during an epidemic in Israel, Am. J. Hyg. 64:259-269.

Marchette, N. J., Halstead, S. B., Falkler, W. A., Jr., Stenhouse, A., and Nash, D., 1973, Studies on the pathogenesis of dengue infection in monkeys. III. Sequential distribution of virus in primary and heterologous infections, J. Infect. Dis. 128:23-30.

Marker, S. C., and Jahrling, P. B., 1979, Correlation between virus-cell receptor properties of alphaviruses in vitro and virulence in vivo, Arch. Virol. 62:53-62.

Marvin, J. A., Zvolanek, E. E., Nowosiwsky, T., and Greenberg, J. H., 1968, Tuberculin sensitivity (TINE) in apparently healthy subjects after yellow fever vaccination, $A m$. Rev. Respir. Dis. 98:703-706.

Mathur, A., Arora, K. L., and Chaturvedi, U. C., 1982, Transplacental Japanese encephalitis virus (JEV) infection in mice during consecutive pregnancies, J. Gen. Virol. 59:213-217.

Mathur, A., Arora, K. L., and Chaturvedi, U. C., 1983a, Immune response to Japanese encephalitis virus in mother mice and their congenitally infected offspring, J. Gen. Virol. 64:2027-2031.

Mathur, A., Arora, K. L., and Chaturvedi, U. C., 1983b, Host defense mechanisms against Japanese encephalitis virus infection in mice, J. Gen. Virol. 64:805-811.

Mathur, A., Rawat, S., and Chaturvedi, U. C., 1983c, Induction of suppressor cells in Japanese encephalitis virus infected mice, Br. J. Exp. Pathol. 69:336-343.

Mathur, A., Rawat, S., and Chaturvedi, U. C., 1984, Suppressor T cells for delayed-type hypersensitivity to Japanese encephalitis virus, Immunology 52:395-402.

Mayer, V., Gajdosova, E., and Slavik, I., 1976, In vitro studies on cell-mediated immune response to tick-borne encephalitis virus: Findings in convalescents and human subclinical infections, Acta Virol. 20:395-401.

McFarland, R. I., and White, D. O., 1980, Further characterization of natural killer cells induced by Kunjin virus, Aust. J. Exp. Biol. Med. Sci. 58:77-89.

McFarland, H. F., Griffin, D. E., and Johnson, R. T., 1972, Specificity of the inflammatory response in viral encephalitis. I. Adoptive immunization of immunosuppressed mice infected with Sindbis virus, J. Exp. Med. 136:216-226.

McIntosh, B. M., Jupp, P. G., Dos Santos, I., and Meenehan, G. M., 1976, Epidemics of West Nile and Sindbis viruses in South Africa with Culex (Culex) univittatus Theobold as vector, S. Afr. J. Sci. 72:295-300. 
McKenzie, J. L., Dalchau, R., and Fabre, J. W., 1982, Biochemical characterization and localization in brain of a human brain-leucocyte membrane glycoprotein recognized by a monoclonal antibody, $J$. Neurochem. 39:1461-1466.

Miller, C. A., and Benzer, S., 1983, Monoclonal antibody cross-reactions between Drosophila and human brain, Proc. Nat1. Acad. Sci. U.S.A. 80:7641-7645.

Mims, C. A., 1977, The Pathogenesis of Infectious Disease, Academic Press, New York.

Mirovsky, J., Holub, J., and Nguyen-Ba-Can, 1962, The influence of dengue on pregnancy and fetus, Cesk. Pediatr. 17:985-988 (in Czech).

Mitchell, C. J., Gubler, D. J., and Monath, T. P., 1983, Variation in infectivity of St. Louis encephalitis viral strains for Culex pipiens quinquefasciatus (Diptera: Culicidae), I. Med. Entomol. 20:526-533.

Mitrakul, C., Poshyachinda, M., Futrakul, P., Sangkawibha, N., and Ahandrik, S., 1977, Hemostatic and platelet kinetic studies in dengue hemorrahagic fever, Am. J. Trop. Med. Hyg. 26:975-984.

Miyake, M., 1964, The pathology of Japanese encephalitis: A review, Bull. W.H.O. 30:153160.

Moench, T. R., and Griffin, D. E., 1984, Immunocytochemical identification and quantification of the mononuclear cells in the cerebrospinal fluid, meninges, and brain during acute viral meningo-encephalitis, J. Exp. Med. 159:77-88.

Monath, T. P., 1971, Neutralizing antibody response in the major immunoglobulin classes to yellow fever 17D vaccination of humans, Am. J. Epidemiol. 93:122-129.

Monath, T. P., 1980, Epidemiology, in: St. Louis Encephalitis (T. P. Monath, ed.), pp. 239312, American Public Health Association, Washington, D.C.

Monath, T. P. C., and Borden, E. C., 1971, Effects of thorotrast on humoral antibody, viral multiplication, and interferon during infection with St. Louis encephalitis virus in mice, J. Infect. Dis. 123:297-300.

Monath, T. P., Kemp, G. E., Cropp, C. B., and Bowen, G. S., 1978, Experimental infection of house sparrows (Passer domesticus) with Rocio virus, Am. I. Trop. Med. Hyg. 27:1251-1254.

Monath, T. P., Craven, R. B., Adjukiewicz, A., Germain, M., Francy, D. B., Ferrara, L., Samba, D. M., N'Jie, H., Cham, K., Fitzgerald, S. A., Crippen, P. H., Simpson, D. I. H., Bowen, E. T. W., Fabiyi, A., and Salaun, J.-J., 1980a, Yellow fever in the Gambia, 1978-1979: Epidemiologic aspects with observations on the occurrence of Orungo virus infections, Am. J. Trop. Med. Hyg. 29:912-928.

Monath, T. P., Cropp, C. B., Bowen, G. S., Kemp, G. E., Mitchell, C. J., and Gardner, J. J., 1980b, Variation in virulence for mice and rhesus monkeys among St. Louis encephalitis virus strains of different origin, Am. J. Trop. Med. Hyg. 29:948-962.

Monath, T. P., Brinker, K. R., Chandler, F. W., Kemp, G. E., and Cropp, C. B., 1981, Pathophysiologic correlations in a rhesus monkey model of yellow fever with special observations on the acute necrosis of B cell areas of lymphoid tissues, Am. J. Trop. Med. Hyg. 30:431-443.

Monath, T. P., Cropp, C. B., and Harrison, A. K., 1983, Mode of entry of a neurotropic arbovirus into the central nervous system: Reinvestigation of an old controversy, Lab. Invest. 48:399-410.

Monath, T. P., Nystrom, R. R., Bailey, R. E., Muth, D. J., and Calisher, C. H., 1984, IgM antibody capture ELISA for diagnosis of St. Louis encephalitis, I. Clin. Microbiol. 20: 784-790.

Murphy, F. A., 1979, Viral pathogenetic mechanisms, in: Mechanisms of Viral Pathogenesis and Virulence (P. A. Bachmann, ed.), pp. 7-19, WHO Collaborating Center for Collection and Evaluation of Data on Comparative Virology, Munich.

Murphy, F. A., Harrison, A. K., Gary, F. W., Jr., Whitfield, S. G., and Forrester, F. T., 1968, St. Louis encephalitis virus infection of mice: Electron microscopic studies of the central nervous system, Lab. Invest. 19:652-662.

Museteanu, C., Welte, M., Henneberg, G., and Haase, J., 1979, Relation between decreased 
mental efficiency in mice and the presence of cerebral lesions after experimental encephalitis caused by yellow fever virus, I. Infect. Dis. 139:320-323.

Nagarkatti, M., and Nagarkatti, P. S., 1979, Suppression of intrinsic B cell function in dengue infected mice, Experientia 35:1518-1519.

Nagarkatti, M., Nagarkatti, P. S., and Rao, K. M., 1980, Effects of experimental dengue virus infection on humoral and cell-mediated immune response to thymus-dependent antigen, Int. Arch. Allergy Appl. Immunol. 62:361-369.

Nagarkatti, P. S., and Nagarkatti, M., 1983, Effect of experimental dengue virus infection on immune response of the host. I. Nature of changes in T suppressor cell activity regulating the B and $\mathrm{T}$ cell responses to heterologous antigens, J. Gen. Virol. 64:14411447.

Nagarkatti, P. S., D'Souza, M. B., and Rao, K. M., 1978, Use of sensitized spleen cells in capillary tube migration inhibition tests to demonstrate cellular sensitization to dengue virus in mice, J. Immunol. Methods 23:341-348.

Nathanson, N., 1980, Pathogenesis, in: St. Louis Encephalitis (T. P. Monath, ed.), pp. 201236, American Public Health Association, Washington, D.C.

Nathanson, N., and Harrington, B., 1967, Experimental infection of monkeys with Langat virus. II. Turnover of circulating virus, Am. I. Epidemiol. 85:494-503.

Nathanson, N., Davis, M., Thind, I. S., and Price, W. H., 1966, Histological studies of the neurovirulence of group B arboviruses. II. Selection of indicator centers, Am. J. Epidemiol. 84:524-540.

Nawrocka, E., 1975, Characteristics of tick-borne encephalitis virus circulating in Poland, Acta Microbiol. Pol. Ser. A 7:237-245.

Nelson, E. R., Bierman, H. R., and Chulajata, R., 1964, Hematologic findings in the 1960 hemorrhagic fever epidemic (dengue) in Thailand, Am. J. Trop. Med. Hyg. 13:642-649.

Nolan, J. P., 1981, Endotoxin, reticuloendothelial function, and liver injury, Hepatology 1:458-465.

Nosek, J., Gresikova, M., and Rehacek, J., 1960, Persistence of tick-borne encephalitis virus in hibernating bats, in: Biology of Viruses of the Tick-Borne Encephalitis Complex $(\mathrm{H}$. Libikova, ed.), pp. 394-396, Academic Press, New York.

Oaten, S. W., Webb, H. E., and Bowen, E. T. W., 1976, Enhanced resistance of mice to infection with Langat (TP21) virus following pre-treatment with Sindbis or Semliki Forest virus, J. Gen. Virol. 23:381-388.

Oaten, S. W., Webb, H. E., and Jagelman, S., 1980, Resistance of mice to infection with West Nile virus following pre-treatment with Sindbis, Semliki Forest and chikungunya viruses, Microbios Lett. 13:85-90.

Odelola, H. A., and Fabiyi, A., 1978, Kinetic haemagglutination-inhibition technique as a means of detecting antigenic variations among strains of Nigerian flaviviruses, Arch. Virol. 56:291-295.

Ogasa, A., Yokoki, Y., Fujisaki, Y., and Habu, A., 1977, Reproductive disorders in boars infected experimentally with Japanese encephalitis virus, Ipn. J. Anim. Reprod. 23:171175.

Ogawa, M., Okubo, H., Tsuji, Y., Yasui, N., and Someda, K., 1973, Chronic progressive encephalitis occurring 13 years after Russian spring summer encephalitis, J. Neurol. Sci. 19:363-373.

O'Leary, J. L., Smith, M. G., and Reames, H. R., 1942, Influence of age on susceptibility of mice to St. Louis encephalitis virus and on the distribution of lesions, J. Exp. Med. 75:233-247.

Olson, L. C., Sithisarn, P., and Djinawi, N. K., 1975, Role of macrophages in Wesselsbron and Germiston virus infections of mice, J. Infect. Dis. 131:119-127.

Oudart, J.-L., and Rey, M., 1970, Proteinurie, proteinémie, et transaminasemies dans 23 cas de fièvre jaune confirmées, Bull. W.H.O. 42:95-102.

Pang, T., 1983, Delayed type hypersensitivity: Probable role in the pathogenesis of dengue hemorrhagic fever/dengue shock syndrome, Rev. Infect. Dis. 5:346-352. 
Pang, T., Wong, P. Y., and Pathmanathan, R., 1982, Induction and characterization of delayed type hypersensitivity to dengue virus in mice, $J$. Infect. Dis. 146:235-242.

Pang, T., Devi, S., Yeen, W. P., McKenzie, I. F. C., and Leong, Y. K., 1984, Lyt phenotype and $\mathrm{H}-2$ compatability requirements of effector cells in the delayed-type hypersensitivity response to dengue virus infection, Infect. Immun. 43:429-431.

Parks, J. J., Ganaway, J. R., and Price, W. H., 1958, Studies on immunologic overlap among certain arthropod-borne viruses. III. A laboratory analysis of three strains of West Nile virus which have been studied in human cancer patients, Am. J. Hyg. 68:106-119.

Pavri, K. M., and Prasad, S. R., 1980, T suppressor cells: Role in dengue hemorrhagic fever and dengue shock syndrome, Rev. Infect. Dis. 2:142-146.

Pavri, K. M., Ghalsasi, G. R., Dastur, D. K., Goverdhan, M. K., and Lalitha, V. S., 1975, Dual infections of mice: Visceral larva migrans and sublethal infections with Japanese encephalitis virus, Trans. R. Soc. Trop. Med. Hyg. 69:99-110.

Pavri, K. M., Swe Than, Ramamoorthy, C. L., and Chodankar, V. P., 1979, Immunoglobulin $\mathrm{E}$ in dengue hemorrhagic fever (DHF) cases, Trans. R. Soc. Trop. Med. Hyg. 73:451452.

Pavri, K. M., Ramamoorthy, C. L., and Dhorje, S., 1980, Immunoglobulin E in patients with Japanese encephalitis, Infect. Immun. 28:290-291.

Peck, J. L., Jr., and Sabin, A. B., 1947, Multiplication and spread of the virus of St. Louis encephalitis in mice with special emphasis on its fate in the alimentary tract, J. Exp. Med. 85:647-662.

Peiris, J. S. M., and Porterfield, J. S., 1979, Antibody mediated enhancement of flavivirus replication in macrophage-like cell lines, Nature (London) 282:509-511.

Penna, H. A., and Bittencourt, A., 1943, Persistence of yellow fever virus in brains of monkeys immunized by cerebral inoculation, Science 97:448-449.

Perelman, A., and Stern, J., 1974, Acute pancreatitis is West Nile fever, Am. J. Trop. Med. Hyg. 23:1150-1152.

Perelmutter, L., Phipps, P., and Potvin, L., 1978, Viral infections and IgE levels, Ann. Allergy 41:158-159.

Phillpotts, R. J., Stephenson, J. R., and Porterfield, J. S., 1985, Antibody dependent enhancement of tick-borne encephalitis infectivity, J. Gen. Virol. 66:1831-1837.

Pogodina, V. V., Frolova, M. P., Malenko, G. V., Fokina, G. I., Levina, C. S., Mamonenko, L. L., Koreshkova, G. V., and Ralf, N. M., 1981a, Persistence of tick-borne encephalitis virus in monkeys. I. Features of experimental infection, Acta Virol. 25:337-343.

Pogodina, V. V., Levina, L. S., Fokina, G. I., Koreshkova, G. V., Malenko, G. V., Bochkova, N. A., and Rzhakhova, O., 1981b, Persistence of tick-borne encephalitis virus in monkeys. III. Phenotypes of the persisting virus, Acta Virol. 25:352-360.

Pogodina, V. V., Frolova, M. P., Malenko, G. V., Fokina, G. I., Koreshkova, L. L., Kiseleva, N. G., Bochkova, N. G., and Ralph, N. M., 1983, Study of West Nile virus persistence in monkeys, Arch. Virol. 75:71-86.

Pongpanich, B., and Kumponpant, S., 1973, Studies of dengue hemorrhagic fever. V. Hemodynamic studies of clinical shock associated with dengue hemorrhagic fever, $J$. Pediatr. 83:1073-1077.

Price, W. H., 1966, Chronic disease and virus persistence in mice inoculated with Kyasanur Forest disease virus, Virology 29:679-681.

Putvatana, R., Yoksan, S., Chayaydohin, T., Bhamarapravati, N., and Halstead, S., 1984, Absence of dengue 2 infection enhancement in human sera containing Japanese encephalitis, Am. J. Trop. Med. Hyg. 33:288-294.

Reeves, W. C., Bellamy, R. E., and Scrivani, R. P., 1958, Relationships of mosquito vectors to winter survival of encephalitis viruses. I. Under natural conditions, Am. I. Hyg. 67:78-89.

Reid, H. W., 1975, Experimental infection of red grouse with louping ill virus (flavivirus group|. I. The viraemia and antibody response, J. Comp. Pathol. 85:223-229.

Reid, H. W., and Doherty, P. C., 1971, Louping ill encephalomyelitis in the sheep. I. The 
relationship of viremia and the antibody response to susceptibility, J. Comp. Pathol. 81:521-527.

Reid, H. W., and Moss, R., 1980, The response of four species of birds to louping ill, in: Arbovirus in the Mediterranean Countries (J. Vesenjak-Hirjan, J. S. Porterfield, and E. Arslanagic, eds.), Abh. Bakteriol. Suppl. 9:219-223, Gustav Fischer Verlag, Stuttgart.

Reid, H. W., Doherty, P. C., and Dawson, A. M., 1971, Louping ill encephalomyelitis in the sheep. III. Immunoglobulins in cerebrospinal fluid, J. Comp. Pathol. 81:537-543.

Reid, H. W., Buxton, D., Pow, I., and Finlayson, J., 1982, Experimental louping ill virus infection in two species of British deer, Vet. Rec. 111:61.

Repik, P. M., Dalrymple, J. M., Brandt, W. E., McCown, J. M., and Russell, P. K., 1983, RNA fingerprinting as a method for distinguishing dengue 1 virus strains, Am. J. Trop. Med. Hyg. 32:577-589.

Reyes, M. G., Gardner, J. J., Poland, J. D., and Monath, T. P., 1981, St. Louis encephalitis: Quantitative histologic and immunofluorescent studies, Arch. Neurol. 38:329-334.

Roehrig, J. T., Mathews, J. H., and Trent, D. W., 1983, Identification epitopes on the E glycoprotein of St. Louis encephalitis virus using monoclonal antibodies, Virology 128:118-126.

Rosemberg, S., 1977, Neuropathological study of a new viral encephalitis: The encephalitis of Sao Paulo South Coast, Rev. Inst. Med. Trop. Sao Paulo 19:280-282.

Rubenstein, D., Wheelock, E. F., and Tyrrell, D. A. J., 1972, The growth of arboviruses in organ culture of mouse meninges and the influence on in vitro virus growth of previous vaccination, Proc. Soc. Exp. Biol. Med. 140:1123-1126.

Russell, P. K., and Brandt, W. E., 1973, Immunopathologic processes and viral antigens associated with sequential dengue virus infection, Perspect. Virol. 7:263-277.

Sagamata, M., and Miura, T., 1982, Japanese encephalitis virus infection in fetal mice at different stages of pregnancy. I. Stillbirth, Acta Virol. 26:279-282.

Sahaphong, S., Riengrojpitak, S., Bhamarapravati, N., and Chirachariyavej, T., 1980, Electron microscopic study of the vascular endothelial cell in dengue hemorrhagic fever, Southeast Asian J. Trop. Med. Public Health 11:194-211.

Sanders, M., Blumberg, A., and Haymaker, W., 1953, Polyradiculopathy in man produced by St. Louis encephalitis virus (SLE), South. Med. J. 46:606-611.

Sangkawibha, N., Rojanasuphot, S., Ahandrik, S., Viriyapongse, S., Jatanasen, S., Salitul, V., Phanthumachinda, B., and Halstead, S. B., 1984, Risk factors in dengue shock syndrome: A prospective epidemiologic study in Rayong, Thailand. I. The 1980 outbreak, Am. I. Epidemiol. 120:653-669.

Santos, F., Lima, C. P., Paiva, M., Costa e Silva, M., and Nery de Castro, C., 1973, Coagulacao intravascular disseminada aguda na febre amarela: Dosagem dos fatores da coagulacao, Bras.-Med. 9:9-16.

Santos Lagresa, M. N., Villaescusa, R., Ballester, J. M., and Hernandez, P., 1983, Indomethacin-mediated enhancement of lymphocyte response to phytohemagglutinin in dengue haemorrhagic fever patients, Br. J. Haematol. 55:379-380.

Schlesinger, J. J., and Brandriss, M. W., 1981, Growth of 17D yellow fever virus in a macrophage-like cell line U937: Role of Fc and viral receptors in antibody mediated infection, J. Immunol. 127:659-665.

Schlesinger, R. W., 1977, The Dengue Viruses. Virology Monographs, Vol. 16, SpringerVerlag, Vienna and New York.

Schlesinger, R. W., 1980, Virus-host interactions in natural and experimental infections with alphaviruses and flaviviruses, in: The Togaviruses (R. W. Schlesinger, ed.), pp. 83106, Academic Press, New York.

Scott, R. McN., Nisalak, A., Cheamudon, U., Seridhoranakul, S., and Nimmannitya, S., 1980, Isolation of dengue viruses from peripheral blood leukocytes of patients with hemorrhagic fever, I. Infect. Dis. 141:1-6.

Seamer, J., and Peto, S., 1969, A method of assessment of central nervous function in mice with viral encephalomyelitis, Lab. Anim. 3:129-140. 
Semenov, B. F., Khozinsky, V. V., and Vargin, V. V., 1975, The damaging action of cellular immunity in flavivirus infections of mice, Med. Biol. 53:331-336.

Shaikh, B. H., Pavri, K. M., Ramamoorthy, C. L., Verma, S. P., and Deuskar, N. J., 1983, Total serum immunoglobulins in Japanese encephalitis patients with high IgE levels in acute phase, Indian J. Med. Res. 77:765-769.

Shankar, S. K., Rao, T. V., Mruthyun-Jayanna, B. P., Devi, M. G., and Deshpande, D. H., 1983, Autopsy study of brains during an epidemic of Japanese encephalitis in Karnataka, India, Indian I. Med. Res. 78:431-440.

Sheahan, B. J., Gates, M. C., Caffrey, J. F., and Atkins, G. J., 1983, Oligodendrocyte infection and demyelination produced in mice by the M9 mutant of Semliki Forest virus, Acta Neuropathol. 60:257-265.

Sheets, P., Schwartz, A., Jacoby, R. O., and Bhatt, P. N., 1979, T cell-mediated cytotoxicity for L929 fibroblasts infected with Banzi virus (flavivirus), J. Infect. Dis. 140:384-391.

Shukla, M. I., and Chaturvedi, U. C., 1982, In vivo role of macrophages in transmission of dengue virus-induced suppressor signal to T lymphocytes, Br. J. Exp. Pathol. 63:522530 .

Shukla, M. I., and Chaturvedi, U. C., 1983, Transmission of dengue-virus induced suppressor signal from macrophage to lymphocyte occurs by cell contact, Br. J. Exp. Pathol. 64:8792.

Shukla, M. I., and Chaturvedi, U. C., 1984, Study of the target cell of the dengue virusinduced suppressor signal, Br. J. Exp. Pathol. 65:267-273.

Shukla, M. I., Dalakoti, H., and Chaturvedi, U. C., 1982, Ly phenotype of T lymphocytes producing dengue virus-induced immunosuppressive factors, Indian J. Exp. Biol. 20:525-528.

Sipos, J., Ribiczey, P., Gabor, V., Toth, Z., and Bartok, K., 1981, Investigations on blood and cerebrospinal fluid lymphocytes in patients suffering from tick-borne encephalitis, Infection 9:258-263.

Smith, A., 1981, Genetic resistance to lethal flavivirus encephalitis: Effect of host age and immune status and route of inoculation on production of interfering Banzi virus in vivo, Am. J. Trop. Med. Hyg. 30:1319-1323.

Smith, A. L., and Jacoby, R. O., 1986, Immune responses of mice genetically resistant or susceptible to lethal Banzi virus infection (in prep.).

Smith, J. A., Francis, T. I., and David-West, T. S., 1973, Auto-antibodies in acute viral hepatitis, yellow fever, and hepatocellular carcinoma: Clinical and experimental findings, J. Pathol. 109:83-91.

Srichaikul, T., Nimmannitya, S., Artchararit, N., Siriasawakul, T., and Sungpeuk, P., 1977, Fibrinogen metabolism and disseminated intravascular coagulation in dengue hemorrhagic fever, Am. J. Trop. Med. Hyg. 26:525-532.

Stefanopoulo, G. J., and Mollaret, P., 1934, Hemiplegie d'origine cerebrale et névrite optique en cours d'un cas de fièvre jaune, Bull. Mem. Soc. Med. Hop. (Paris) 50:1463-1466.

Stephenson, J. R., Lee, J. M., and Wilton-Smith, P. D., 1984, Antigenic variation among members of the tick-borne encephalitis complex, J. Gen. Virol. 63:81-89.

Stephenson, L. D., 1939, Pathologic changes in nervous system in yellow fever, Arch. Pathol. 27:249-266.

Stollar, V., 1980, Togaviruses in cultured arthropod cells, in: The Togaviruses: Biology, Structure, Replication (R. W. Schlesinger, ed.), pp. 584-622, Academic Press, New York.

Stollar, V., and Shenk, T. E., 1973, Homologous viral interference in Aedes albopictus cultures chronically infected with Sindbis virus, $J$. Virol. 11:592-595.

Suckling, A. J., Pathak, S., Jagelman, S., and Webb, H. E., 1978, Virus-associated demyelination: A model using avirulent Semliki Forest virus infection of mice, J. Neurol. Sci. 39:147-154.

Sugawa, Y., Hiroshi, M., and Yamamoto, S., 1949, Histopathological studies on naturally affected horses with Japanese encephalitis, Bull. Natl. Inst. Anim. Health (Tokyo) 22:9-25.

Sulkin, S. E., and Allen, R., 1974, Virus infections in bats, Monogr. Virol. 8:1-103. 
Sulkin, S. H., Harford, C. G., and Bronfenbrenner, J. J., 1939, Immunization of mice by intranasal instillation of nasopharyngeal washings from cases of St. Louis encephalitis, Proc. Soc. Exp. Biol. Med. 41:427-429.

Sulkin, S. E., Sims, R., and Allen, R., 1966, Studies of arthropod-borne virus infections in Chiroptera. II. Experiments with Japanese B and St. Louis encephalitis in the gravid bat and evidence for transplacental transmission, Am. J. Trop. Med. Hyg. 13:475-481.

Sumarmo, Wilur, H., Jahja, E., Gubler, D. J., Suharyono, W., and Sorenson, K., 1983, Clinical observations on virologically confirmed fatal dengue infections in Jakarta, Indonesia, Bull. W.H.O. 61:693-701.

Suzuki, M., Simizu, B., Yabe, S., Oya, A., and Seto, H., 1981, Effect of cadmium on Japanese encephalitis virus infection in mice. I. Acute and single-dose exposure experiment, Toxicol. Lett. 9:231-235.

Tamura, H., Koyama, T., Kuwanizu, I., Nakamura, I., Ema, M., and Miura, T., 1977, Effect of methylmercury chloride and Japanese encephalitis virus infection on fetus of hamsters, Med. Biol. 9:161-164.

Tandon, P., Chaturvedi, U. C., and Mathur, A., 1979a, Differential depletion of T lymphcytes in the speen of dengue virus-infected mice, Immunology 37:1-6.

Tandon, P., Chaturvedi, U. C., and Mathur, A., 1979b, Dengue virus induced thymus-derived suppressor cells in the spleens of mice, Immunology 38:653-658.

Tarr, G. C., and Hammon, W. McD., 1974, Cross-protection between group B arboviruses: Resistance in mice to Japanese B encephalitis and St. Louis encephalitis viruses induced by dengue virus immunizations, Infect. Immun. 9:909-915.

Theiler, M., 1951, The virus, in Yellow Fever (G. K. Strode, ed.), pp. 39-136, McGraw-Hill, New York.

Theiler, M., and Anderson, C. R., 1975, The relative resistance of dengue-immune monkeys to yellow fever virus, Am. J. Trop. Med. Hyg. 24:115-117.

Theofilopoulos, A. N., Brandt, W. E., Russell, P. K., and Dixon, F. J., 1976, Replication of dengue 2 virus in cultured human lymphoblastoid cells and subpopulations of human peripheral leukocytes, I. Immunol. 117:953-961.

Thind, I. S., and Singh, N. P., 1977, Potentiation of Langat virus infection by lead intoxication-influence on host defenses, Acta Virol. 21:317-325.

Tigertt, W. D., Berge, T. O., Gochenour, W. S., Gleiser, C. A., Eveland, W. D., Vorder Bruegge, C., and Smetana, H. F., 1960, Experimental yellow fever, Trans. N.Y. Acad. Sci. 22:323333.

Tignor, G. H., Smith, A. L., and Shope, R. E., 1984, Utilization of host proteins as virus receptors, in: Concepts in Viral Pathogenesis (A. L. Notkins and M. B. A. Oldstone, eds.), pp. 109-116, Springer-Verlag, New York.

Trent, D. W., Monath, T. P., Bowen, G. S., Vorndam, A. V., Cropp, C. B., and Kemp, G. E., 1980, Variation among strains of St. Louis encephalitis virus: Basis for a genetic, pathogenetic and epidemiologic classification, Ann. N. Y. Acad. Sci. 354:219-237.

Trent, D. W., Grant, J. A., Vorndam, A. V., and Monath, T. P., 1981, Genetic heterogeneity among St. Louis encephalitis virus isolates of different geographic origin, Virology 114:319-332.

Tuchinda, M., Dhorranintra, B., and Tuchinda, P., 1977, Histamine content in 24-hour urine in patients with dengue hemorrhagic fever, Southeast Asian I. Trop. Med. Public Health 8:80-83.

Umrigar, M. D., and Pavri, K. M., 1977, Comparative biological studies on Indian strains of West Nile virus isolated from different sources, Indian J. Med. Res. 65:596-602.

Vereta, L. A., Ostrorskaya, O. V., Kikolaeva, S. P., and Pukhovskaya, N. M., 1983, Detection of natural heterogeneity of natural tick-borne encephalitis virus populations and grouping of strains, Vopr. Virusol. 28:706-710 (in Russian).

Vince, V., and Grcevic, N., 1969, Development of morphological changes in experimental tick-borne meningoencephalitis induces in white mice by different virus doses, $J$. Neurol. Sci. 9:109-130. 
Vorndam, A. V., 1980, Immunization, in: St. Louis Encephalitis (T. P. Monath, ed.), pp. 623-635, American Public Health Association, Washington, D.C.

Warren, A. J., 1951, Landmarks in the conquest of yellow fever, in: Yellow Fever (G. K. Strode, ed.), pp. 6-37, McGraw-Hill, New York.

Webb, H. E., Wight, D. G. D., and Wiernik, G., 1968, Langat virus encephalitis in mice. II. The effect of irradiation, J. Hyg. 66:355-364.

Webb, H. E., Mehta, S., Gregson, N. A., and Leibowitz, S., 1984, Immunological reaction of the demyelinating Semliki Forest virus with immune serum to glycolipids and its possible importance to central nervous system viral autoimmune disease, Neuropathol. Appl. Neurobiol. 10:77-84.

Webb, J. K. G., and Pereira, S., 1956, Clinical diagnosis of an arthropod-borne type of encephalitis in children of North Arcot District, Madras State, India, Indian J. Med. Sci. 10:573-581.

Weiner, L. P., Cole, G. A., and Nathanson, N., 1970, Experimental encephalitis following peripheral inoculation of West Nile virus in mice of different ages, J. Hyg. 68:435-446.

Wheelock, E. F., and Edelman, R., 1969, Specific role of each human leukocyte type in viral infections. III. 17D yellow fever virus replication and interferon production in homogenous leukocyte cultures treated with phytohemagglutinin, J. Immunol. 103:429-436.

Wheelock, E. F., Toy, S. T., and Stjernholm, R. L., 1970, Lymphocytes and yellow fever. I. Transient virus refractory state following vaccination of man with the $17 \mathrm{D}$ strain, $J$. Immunol. 105:1304-1306.

Wong, P. Y., Devi, S., McKenzie, F. C., Yap, Y. L., and Pang, T., 1984, Induction and Ly phenotype of suppressor $\mathrm{T}$ cells in mice during primary infection with dengue virus, Immunology 51:51-56.

Wood, C. S., 1976, ABO blood groups related to selection of human hosts by yellow fever vectors, Hum. Biol. 48:337-341.

Woodall, J. P., and Roz, A., 1977, Experimental milk-borne transmission of Powassan virus in the goat, Am. J. Trop. Med. Hyg. 26:190-192.

World Health Organization, 1971, Third Report, Expert Committee on Yellow Fever, WHO Tech Rep. Ser., No. 479, Geneva.

World Health Organization, 1973, Pathogenesis mechanisms in dengue hemorrhagic fever: Report of an international collaborative study, Bull. W.H.O. 58:117-123.

Yamamoto, M., and Hotta, S., 1981, Response of human leucocytes to yellow fever virus infection in vitro, Kobe J. Med. Sci. 27:165-172.

Zilber, L. A., 1960, Pathogenicity of Far East and Western (European) tick-borne encephalitis viruses in sheep and monkeys, in: Biology of Viruses of the Tick-Borne Encephalitis Complex (H. Libikova, ed.), pp. 260-264, Academic Press, New York.

Zisman, B., Wheelock, E. F., and Allison, A. C., 1971, Role of macrophages and antibody in resistance of mice against yellow fever virus, J. Immunol. 107:236-243.

Zlotnik, I., and Grant, D. P., 1976, Further observations on subacute sclerosing encephalitis in adult hamsters: The effects of intranasal infections with Langat virus, measles virus and SSPE-measles virus, Br. J. Exp. Pathol. 57:49-66.

Zlotnik, I., Smith, C. E. G., Grant, D. P., and Peacock, S., 1970, The effect of immunosuppression on viral encephalitis with special reference to cyclophosphamide, Br. J. Exp. Pathol. 51:434-439.

Zlotnik, I., Grant, D. P., Carter, G. B., and Batter-Hatton, D., 1973, Subacute sclerosing encephalitis in adult hamsters infected with Langat virus, Br. J. Exp. Pathol. 54:29-39.

Zlotnik, I., Grant, D. P., and Carter, G. B., 1976, Experimental infection of monkeys with viruses of the tick-borne encephalitis complex: Degenerative cerebellar lesions following inapparent forms of the disease or recovery from clinical encephalitis, Br. J. Exp. Pathol. 57:200-210. 